UNIVERSIDADE DE SÃO PAULO

FACULDADE DE FILOSOFIA, LETRAS E CIÊNCIAS HUMANAS

DEPARTAMENTO DE LETRAS ORIENTAIS

PROGRAMA DE LITERATURA E CULTURA RUSSA

ANA MARIA NOVI HOSHIKAWA

\title{
Anton Tchékhov e Tennessee Williams: dramaturgias em comparação
}




\section{Anton Tchékhov e Tennessee Williams: dramaturgias em comparação}

Dissertação apresentada ao Programa de Pós-graduação em Literatura e Cultura Russa do Departamento de Letras Orientais da Faculdade de Filosofia, Letras e Ciências Humanas da Universidade de São Paulo como requisito para obtenção do título de Mestre em Literatura e Cultura Russa. Pesquisa desenvolvida com apoio da CAPES

De acordo,

Orientadora: Profa. Dra. Arlete Orlando Cavaliere Ruesch 
Autorizo a reprodução e divulgação total ou parcial deste trabalho, por qualquer meio convencional ou eletrônico, para fins de estudo e pesquisa, desde que citada a fonte.

Catalogação na Publicação

Serviço de Biblioteca e Documentação

Faculdade de Filosofia, Letras e Ciências Humanas da Universidade de São Paulo

$\mathrm{H} 825 \mathrm{a}$

Hoshikawa, Ana Maria Novi

Anton Tchékhov e Tennessee Williams: dramaturgias em comparação /

Ana Maria Novi Hoshikawa; orientadora Arlete Orlando Cavaliere Ruesch. São Paulo, 2015.

$166 \mathrm{f}$.

Dissertação (Mestrado) - Faculdade de Filosofia, Letras e Ciências Humanas da Universidade de São Paulo. Departamento de Letras Orientais. Área de concentração: Literatura e Cultura Russa.

1. Tchékhov, Anton Pávlovitch, 1860-1904. 2. Williams, Tennessee, 1911-1983. 3. Dramaturgia. 4. Teatro Russo. 5. Teatro Americano. I. Ruesch, Arlete Orlando Cavaliere, orient. II. Título 


\section{FOLHA DE APROVAÇÃO}

Ana Maria Novi Hoshikawa

Anton Tchékhov e Tennessee Williams: dramaturgias em comparação

Dissertação de mestrado Apresentada ao Programa de pós-graduação em Literatura e Cultura Russa do Departamento de Letras Orientais da Faculdade de Filosofia, Letras e Ciências Humanas da Universidade de São Paulo.

Aprovado em:

Banca examinadora:

Profa. Doutora Arlete Orlando Cavaliere Ruesch

Faculdade de Filosofia, Letras e Ciências Humanas

Universidade de São Paulo

Orientadora

Prof. Dr.

Instituição:

Assinatura

Prof. Dr.

Instituição:

Assinatura 


\section{AGRADECIMENTOS}

Gostaria de agradecer a todos os professores do programa de Literatura e Cultura russa por tudo que me ensinaram e em tudo que me inspiraram. Também a todos os demais professores que, através de suas aulas e conversas, muito me ajudaram na pesquisa e na vida. Agradeço especialmente aos professores Maria Sílvia Betti, Mayumi Illari e Bruno Gomide, que contribuíram significativamente à minha pesquisa através de suas muitas sugestões, e aos professores Daniel Aarão e Angelo Segrillo, pela disposição a revisar minhas incursões históricas, oferecendo comentários detalhados para meu aprimoramento.

Aos funcionários do departamento de letras orientais também sou grata, especialmente ao Jorge, que sempre me ajudou carinhosamente, aplacando minhas angústias administrativas e corrigindo meus muitos erros burocráticos.

Agradeço à CAPES, pelo fomento de minha pesquisa.

Sobretudo, sou grata à minha orientadora, Arlete Cavaliere, pela paciência que teve em lidar com meus muitos e-mails e pelo apoio constante que me ofereceu, mesmo nas minhas ambições megalomaníacas. Sempre soube quando me frear, sem me reprimir, lembrando-me da importância de ter foco.

Um agradecimento especial vai ao meu pai, minha mãe e ao meu irmão, sem eles, nada teria sido possível. O investimento e aposta em mim foram certamente indispensáveis.

Agradeço aos meus colegas da pós, que foram de grande ajuda com suas indicações e com sua experiência, sobretudo Renata Esteves e Rodrigo Nascimento. Aos amigos da vida, também, que escusaram as minhas ausências, apoiaram minha empreitada e souberam quando me arrastar para fora de casa.

Especialmente, agradeço ao Daniel, que esteve sempre ao meu lado, pacientemente, acompanhando e discutindo, às vezes à revelia, cada passo dado em minha pesquisa, e que nunca falhou em me apoiar. 
vocês conseguissem maravilhar-se, isto é, surpreender-se com este fato tão trivial que nos sucede todos os dias no Teatro. Platão faz constar que o conhecimento nasce dessa capacidade para nos surpreendermos, maravilharmos, assombrarmos de que as coisas sejam como são, precisamente como são."

Ortega y Gasset.

"Quando lançamos o olhar para trás e contemplamos o passado humano, a primeira coisa que vemos são "ruínas". A história é mudança e esta mudança tem, à primeira vista, um aspecto negativo que nos produz pena. $O$ que nele nos deprime é ver como a mais rica criação, a vida mais bela encontra na História seu ocaso. A História é uma viagem ao egrégio. Ela nos arrebata aquelas coisas e seres os mais nobres, os mais belos pelos quais nos havíamos interessado, as paixões e os sofrimentos os destruíam: eram transitórios. Tudo parece ser transitório, nada permanece."

Ortega y Gasset. 
HOSHIKAWA, Ana Maria Novi. Anton Tchékhov e Tennessee Williams: dramaturgias em comparação. São Paulo: 2015, 166f. Dissertação (Mestrado em Literatura e Cultura Russa) Faculdade de Filosofia, Letras e Ciências Humanas, Universidade de São Paulo.

\section{RESUMO}

O presente trabalho apresenta três possibilidades de comparação entre os textos de Anton Tchékhov e Tennessee Williams: a primeira trata-se de uma comparação formal, que investiga as semelhantes soluções dramatúrgicas encontradas pelos autores em relação à crise do drama, conceito elaborado por Peter Szondi; a segunda possibilidade se concentra sobre as semelhantes posições de classe (conceito de P. Bourdieu) encontradas na história russa e na história americana, que servem como substrato temático às peças analisadas; a terceira e última possibilidade de comparação apresentada está baseada no fenômeno de recepção das peças tchekhovianas nos Estados Unidos, considerando também a vasta repercussão das encenações do Teatro de Arte de Moscou sobre a cena americana.

Palavras-chave: Anton Tchékhov; Tennessee Williams; Dramaturgia; Encenação; Teatro Russo; Teatro Americano. 
HOSHIKAWA, Ana Maria Novi. Anton Chekhov and Tennessee Williams: plays in comparison. São Paulo: 2015, 166f. Dissertação (Mestrado em Literatura e Cultura Russa) - Faculdade de Filosofia, Letras e Ciências Humanas, Universidade de São Paulo.

\begin{abstract}
This work presents three distinct possibilities of comparison between the texts of Anton Chekhov and Tennessee Williams: the first one is a formal comparison, it investigates the similar dramatic solutions the authors found to drama's crisis, a concept created by Peter Szondi; the second possibility concentrates over the similarities of class position (P. Bourdieu's concept) found in Russian and Amercian history, these serve as the thematic substract of the plays' analysis; the third and last possibility explored is based upon the reception of Chekhov's plays in the United States, considering the reprecussions of their productions by the Moscow Art Theatre on the American stage.
\end{abstract}

Key words: Anton Chekhov; Tennessee Williams; Dramaturgy; Staging; Russian Theatre; American Theatre. 


\section{Índice}

Apresentação: fundamentos metodológicos 10

1. O Jardim das Cerejeiras, Lady of Larkspur Lotion e A Strangest Kind of Romance:

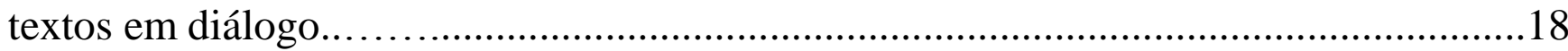

2. As três Irmãs e Um Bonde Chamado Desejo: contextos em diálogo..........................63

3. Questões de recepção: Tennessee - Stanislávski - Tchékhov....................................99

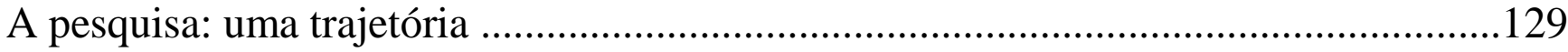

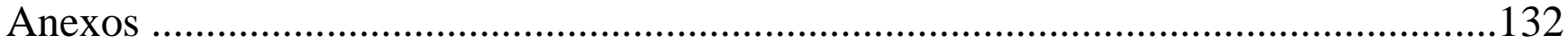

I. $\quad$ Breve comentário e tradução de: $O$ nascimento de uma arte ..................133

II. Reportagens selecionadas do new york times ........................................146

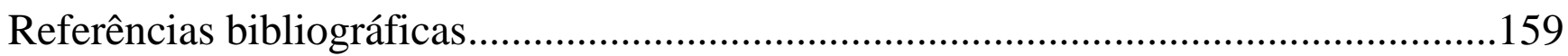




\section{Apresentação: fundamentos metodológicos}

Following a hunch means trusting an implicit promise for a while and making a step toward describing a phenomenon that remains unknown - one that has aroused our curiosity and, in the case of atmospheres and moods, often envelops and enshrouds us.

GUMBRECHT, H.U.. ${ }^{1}$

A epígrafe acima, de maneira geral, resume o percurso do presente trabalho. Seu tema, a investigação de traços tchekhovianos na escrita dramatúrgica do início da carreira de Tennessee Williams, foi sugerido por um palpite ("hunch"), perseguido durante a pesquisa na tentativa de entender como ele havia se formado. Um breve desvio inicial pode elucidar a trajetória da pesquisa aqui apresentada.

Com base na (controversa) proposta de Gumbrecht de analisar a literatura a partir do stimmung - ou atmosfera, como tradução mais próxima -, é possível afirmar que o palpite de que Anton Tchékhov e Tennessee Williams guardavam algo similar entre si foi gerado por uma semelhança de atmosferas entre a peça Lady of Larkspur Lotion e os textos de Tchékhov. Não se tratava de uma semelhança visivelmente clara, como conteúdos muito próximos, nem técnicas de escrita que se parecessem, como um estilo linguístico particular, mas um ressoar sutil, inefável e reminiscente de um no outro. A sutileza, mais tarde percebida, estava nas semelhanças entre os escritores, contidas mais em estruturas do que nos elementos em si, ou seja, na forma por meio da qual construíam suas peças e como ela refletia sobre o conteúdo, não no próprio conteúdo. Essas semelhanças estavam também nas confluências de valores que sustentavam essa forma, presentes na cultura ocidental, como, por exemplo, o pressuposto de que o indivíduo não é livre para atuar sobre

${ }^{I}$ GUMBRECHT, H.U. Atmosphere, mood, stimmung - On a hidden Potential of Literature. Edição Kindle. Stanford: Stanford University Press, 2012. LOC 302

Tradução:

Seguir um palpite significa confiar por um tempo numa promessa implícita e dar um passo rumo à descrição de um fenômeno que permanece desconhecido - um que nos tenha despertado a curiosidade e, no caso de atmosferas e humores, frequentemente nos engole e encobre. (Tradução nossa. Todas as demais traduções presentes nas notas de rodapé são de nossa autoria, a não ser quando indicado o contrário.) 
seu próprio destino e a percepção da incomunicabilidade gerada a partir da fragmentação da antiga harmonia clássica.

O palpite, então, tornou-se objeto de pesquisa: circunscritos os possíveis elementos de contato, surgiram os desdobramentos de seus eixos mais marcantes. A horizontalidade do estudo se devea uma extrema curiosidade e pelo fato de existir como uma investigação introdutória, uma tentativa de alargamento das possibilidades de acesso às obras desses importantes dramaturgos. Ela se desdobrou, como se verá na própria organização dos capítulos, em três diferentes eixos: histórico, formal e da recepção. A investigação de cada um deles procurou se manter sempre próxima às peças, para não incorrer em devaneios teóricos desvinculados do foco da pesquisa.

Considerando a origem social das formas artísticas, a pesquisa teve início em uma investigação histórico-social. Ambos os países encontravam-se num momento de transformações econômicas, no qual duas ideologias de classe, com todo seu aparato cultural, estavam em conflito. Na Rússia, a ascensão de uma classe burguesa ${ }^{2}$ evidenciava a lenta queda da aristocracia, enquanto nos Estados Unidos, as culturas aristocráticas do sul, após a Guerra Civil, se esfacelavam dentro de um sistema econômico que lhes era adverso. As tensões geradas pela adaptação de determinados setores sociais à nova dinâmica econômica, a ascensão da cultura burguesa e seu materialismo e pragmatismo iniciais, todo esse complexo movimento histórico pode ser encontrado nas formas particulares que os autores em questão adotaram. A maneira específica na qual tais temas surgem como conteúdo subjacente nos textos encontra-se no capítulo segundo.

O terceiro eixo da pesquisa se desenvolveu em torno da recepção americana dos trabalhos de Tchékhov. Trata-se de tentar entender em qual contexto Tennessee teria recebido a obra tchekhoviana. Descobriu-se, principalmente por meio dos estudos de Laurence Senelick e Valleri Hohman ${ }^{3}$, que, para sua aceitação, foi necessária a turnê de Stanislávski nos Estados Unidos. Muito semelhante ao que havia acontecido na Rússia com seus textos, era indispensável uma nova forma de expressão dramática para que a dramaturgia de Tchékhov fosse contemplada como possibilidade cênica. Após a turnê, chegou-se a afirmar que nenhum dramaturgo americano surgiria sem ter o Teatro de Arte de

\footnotetext{
${ }^{2}$ Tratava-se de uma segunda camada de burgueses, agora ligados à indústria que se desenvolvia, não mais somente aos setores mercantis.

${ }^{3}$ SENELICK, Laurence. The Chekhov Theatre. Cambridge: Cambridge University Press, 1997.

HOHMAN, Valleri J. Russian Culture and Theatrical Performance in America - 1891-1933. New York: Palmgrave Mcmillan, 2011.
} 
Moscou e a obra de Tchékhov como referência.

Para tratar das peculiaridades formais comuns entre Tennessee e Tchékhov, optou-se por contrastar suas formas àquelas do drama burguês (segundo caracterização de P. Szondi ${ }^{4}$ ), para mapear as transformações ocorridas na forma sempre em relação ao seu contexto histórico-social. A chamada crise do drama foi um conceito importante para a elaboração da análise comparativa, pois por meio dele pode-se inserir as inovações técnicas dos escritores na história da dramaturgia como um todo. $\mathrm{O}$ capítulo 1 é inteiramente dedicado à elaboração desses conceitos, como também à sua efetiva aplicação nos textos analisados.

Não obstante a centralidade de Szondi para o trabalho, importou matizar seu conceito de drama moderno incorporando considerações de Lukács e Hauser ${ }^{5}$ acerca do gênero. Tratou-se de uma opção teórica considerar o processo de desenvolvimento da forma dramática de maneira mais fluida, inserindo-o dentro do desenvolvimento cultural como um todo, ao lado, por exemplo, do desenvolvimento do gênero do romance. Por se tratar de uma discussão complexa e de grande importância para o tema desta pesquisa, um amplo espaço será dedicado a ela.

A problemática do gênero dramático surgiu em momento já tardio do estudo, em grande medida, suscitada pelas considerações feitas ao trabalho no momento do exame de qualificação. Se, por um lado, acredita-se que tal problemática agrega mais valor ao tema por clarificar muitas das decisões tomadas durante o percurso de investigação, por outro, é certo, não se pretende exauri-la. A proposta essencial é uma reflexão inicial, durante a qual, espera-se, dar conta dos diversos conceitos que serão utilizados no desenvolvimento do presente trabalho.

$* * *$

\footnotetext{
${ }^{4}$ SZONDI, Peter. Teoria do Drama Burguês. São Paulo: Cosac Naify, 2004.

${ }^{5}$ HAUSER, Arnold. História Social da Arte e de Literatura. São Paulo: Martins Fontes, 2003. —. The Sociology of Art. Edição para Kindle. New York: Routledge, 1982. LUKÁCS, Gyorgi. Il Dramma Moderno. Milão: SugarCo Se Edizioni, 1967.

—. "The Sociology of Modern Drama." The Tulane Drama Review Vol. 9. No.4, verãode 1965: 146-170.
} 
Em seu livro dedicado ao drama burguês, Peter Szondi ${ }^{6}$ afirma, diferentemente de muitos pesquisadores, que a formulação normativa desse gênero raríssimas vezes, senão nunca, foi seguida à risca, mesmo pelos dramaturgos que a advogavam. Os pressupostos formais que tal drama deveria seguir pareciam apoiar-se firmemente na ideologia burguesa do século XVIII, afirmando valores que lhes eram importantes como classe, como a liberdade individual, o poder de autodeterminação que leva à possibilidade do sujeito estar em controle de seu próprio destino, a disposição à ação concreta etc.

Como se verá em mais detalhe no capítulo dedicado à crise do drama, a forma defendida por escritores como George Lillo e Diderot, em seu próprio mecanismo interno, depende de expedientes formais que confirmam tais perspectivas ontológicas. Para seu andamento, o drama burguês depende inteiramente de suas personagens, que devem enunciar suas ações e executá-las progressivamente, numa relação clara e imediata de causa e efeito. Há, além disso, em sua estrutura, uma evidente divisão entre personagens positivas e negativas, entre o bem e o mal, que se refere, em larga medida, à característica moralidade da burguesia da época - caráter por eles acentuado como oposição às extravagâncias da aristocracia.

Os temas de tais peças, apesar de se expandirem para classes até então ignoradas pelo drama, não tratam de maneira direta do conflito de classes em que a burguesia tenta se impor contra a aristocracia. Mas, considerando a afirmação de Lukács de que o verdadeiramente social é a forma ${ }^{7}$, pode-se perceber que tais conflitos existiam, menos como denúncia do que como a nítida afirmação, pela forma, de uma perspectiva na qual o modelo de homem burguês seria o ideal. É interessante, no entanto, pensar nas possíveis razões que levariam essa fórmula dramática a não ser seguida de

\footnotetext{
${ }^{6}$ SZONDI, P. 2004.

${ }^{7}$ LUKÁCS, G. 1967. p.9.
}

“Gli errori maggiori dellánalisi sociologica rispetto all'arte sono: nelle creazioni artistiche essa ricerca ed esamina solo i contenuti e traccia uma linea retta tra questi e i dati rapporti economici. Ma nella letteratura il vero sociale è la forma. Solo la forma trasforma in comunicazione l'esperienzia che il poeta compie stando com altri, cioè col suo pubblico. L'arte, solo allora, diventa sociale, viene socializzata proprio da questa comunicazione $<<$ formata $\rangle$, dalla possibilità dell'effeto e dell'effeto de fatto insorgente".

Tradução:

Os maiores erros da análise sociológica a respeito da arte são: na criação artística ela pesquisa e examina somente os conteúdos e traça um linha reta entre estes e os dados econômicos. Mas na liteartura o verdadeiramente social é a forma. Só a forma transforma em comunicação a experiência que o poeta executa estando com outros, isto é, com seu público. A arte, só então, torna-se social, a socialização se dá precisamente por esta comunicação "formal", da possibilidade de efeito e do efeito de fato insurgente. 
maneira tão normativa quanto era defendida.

Se, como afirma Adorno, forma é conteúdo social sedimentado ${ }^{8}$, ela não pode se sustentar somente sobre uma ideologia e suas promessas. Vislumbres de uma realidade social na qual tais promessas não são cumpridas, como foi historicamente comprovado, hão de transparecer nas obras, gerando um conflito entre a forma rígida que era desejada e o produto artístico de fato. Os elementos que Szondi considera evidências de uma crise do drama ${ }^{9}$, em pequena medida, já estariam enunciados no próprio drama burguês.

O desenvolvimento formal do drama moderno já carrega, em sua forma, perspectivas muito menos otimistas ou, na verdade, idealistas. O modelo do homem burguês nunca foi confirmado pelo processo histórico, a liberdade do sujeito, tão logo se instalaram as relações capitalistas de mercado, foi questionada mais do que anteriormente, à sombra do cristianismo. Os indivíduos, como já em 1837 nos mostra Woyzeck, de George Büchner, pouco tinham de escolhas e poder, sendo absolutamente condicionados pelas estruturas objetivas nas quais se inseriam, restando-lhes como espaço somente atos de irracionalidade.

O drama moderno como "evolução" do drama burguês, no sentido de progressão no desenvolvimento do gênero, carrega em si uma contradição que tem como raiz os dois grandes pilares de sustentação do paradigma romântico: o individualismo e sua crença no homem como potência - já presente em seu antecessor - e a consciência histórica. Lukács ${ }^{10}$ considera essa contradição aquilo mesmo que permite a nova forma dramática, propondo que o sofrimento e a ação não são tão diferentes entre si.

Em um mundo sem Deus, cabe ao homem o seu destino, e de suas ações e escolhas saem as

\footnotetext{
${ }^{8}$ ADORNO, Theodore. Aesthetic Theory. Edição: Gretel Adorno e Rolf Tiedemann. Tradução: Robert Hullot-Kentor. Londres: Bloomsbury Revelation, 2013. LOC 338

"If art opposes the empirical through the element of form - and the mediation of form and content is not to be grasped without their differentiation - the mediation is to be sought in the recognition of aesthetic form as sedimented content."

Tradução:

Se a arte opõe o empírico por meio da forma - e a mediação entre forma e conteúdo não deve ser entendido sem a diferenciação entre os dois - a medição deve ser buscada no reconhecimento da forma estética como conteúdo sedimentado. Para uma introdução detalhada à problemática, ver capítulo Sinta o Drama, em Sinta o Drama, de Iná Camargo Costa (Sinta o Drama. Petrópolis: Editora Vozes, 1998).

${ }^{9}$ SZONDI, Peter. Teoria do Drama Moderno. 2a Edição. São Paulo: Cosac Naify, 2012.

${ }^{10}$ LUKÁCS, G. 1967.
} 
consequências de seu futuro; perspectiva corroborada pela ideologia capitalista. Gumbrecht, em referência ao estudo de Koselleck, cita seis características que definem o cronotopo vigente durante o século XIX, o cronotopo do pensamento ou da consciência histórica:

First, 'historically conscious' mankind imagines itself on a linear path moving through time (therefore, it is not time itself that moves, as occurs in other chronotopes). Second, "historical thought" presumes that all phenomena are affected by change in time - time appears, that is, as an absolute agent of transformation. Third, as mankind moves along in time, it thinks it has left the past behind; the distance afforded by the present moment depreciates the value of past experiences as points of orientation. Fourth, the future presents itself as an open horizon of possibilities toward which humanity is mankind its way. Between the future and the past - and this is point five - the present narrows to a "brief, no-longer-perceptible moment of transition" (in the words of Baudelaire). It is my belief - point six - that the constricted present of this "history" came to provide the Cartesian subject with its epistemological habitat. Here was the site where the subject, adapting experiences from the past to the present and the future, made choices among the possibilities the latter offered. Picking options from what the future holds is the basis of - and frame for - what we call agency (Handeln). ${ }^{11}$,

Como se pode ver, até em sua relação com o tempo - muito similar, inclusive, ao tempo do drama burguês, uma expressão das crenças de base do paradigma burguês - a cultura do século XIX tinha já enraizada a confiança no poder de ação do homem.

Por outro lado, essa aguçada consciência histórica, evidencia cada vez mais que, ao contrário do que se acredita, o homem é condicionado por suas circunstâncias, de modo que suas ações são limitadas e, mais que isso, suas consequências parecem inócuas perante a realidade.

\footnotetext{
${ }^{11}$ GUMBRECHT, H.U. Our Broad Present - Time and Contemporary Culture. New York: Columbia University Press, 2014. LOC 152.
}

Tradução:

Primeiro, a humanidade "historicamente consciente" se imagina num caminho linear, se movendo através do tempo (portanto, não é o tempo em si que se move, como ocorre em outros cronotopos). Segundo, o "pensamento histórico" pressupõe que todos os fenômenos são afetados por mudanças no tempo - o tempo aparece, isto é, como agente absoluto de transformação. Terceiro, conforme a humanidade se move no tempo, ela pensa que deixou o passado para trás; a distância concedida pelo momento presente deprecia o valor das experiências passadas como pontos de orientação. Quarto, o futuro se apresenta como um horizonte aberto de possibilidades rumo ao qual a humanidade está caminhando. Entre o futuro e o passado - e este é o ponto cinco - o presente se estreita e se torna um 'curto, imperceptível momento de transição' (nas palavras de Baudelaire). Creio - ponto seis - que o presente constrito dessa 'história' providenciou ao sujeito cartesiano o seu habitat epistemológico. Aqui (agora) era o local de onde o sujeito, adaptando experiências do passado para o presente e para o futuro, fazia suas escolhas dentre as possibilidades que o futuro oferecia. Escolher opções dentre o que o futuro promete é a base - e a moldura - para aquilo que chamamos agência. (Handeln) 
The more that circumstances define man, the more difficult this problem seems, and the more the very atmosphere appears to absorb all into itself. Man, distinct contours, no longer exists; only air, only atmosphere. All that modern life has introduced by way of enriching the perceptions and emotions seems to vanish into atmosphere, and the composition is what suffers... ${ }^{12}$

Segundo Lukács, está no conflito entre o poder de resistência da vontade do homem e a percepção de que ele nada mais é do que a intersecção de forças externas, a nova forma do drama moderno, que passa a situar seu conflito na subjetividade de suas personagens em relação ao hostil mundo externo. Como se verá nos demais capítulos, as peças de Anton Tchékhov e de Tennessee Williams seguem exatamente esse modelo. Seus dramas não possuem ação e conflitos aparentes, como eram aqueles do drama burguês; eles desenvolvem-se somente em suas atmosferas, como que exemplificando situações banais de existência.

Que o tempo ainda guarda em si seu passado romântico é um fato que muitos pesquisadores e filósofos já apontaram. Talvez nesse fato resida uma das possíveis explicações do porquê do contínuo interesse pela obra dramatúrgica de Tchékhov e de Tennessee Williams, especialmente pelas peças do início de sua carreira. Durante o período desta pesquisa, muitas das peças de ambos estiveram em cartaz em São Paulo ${ }^{13}$, o que faz supor que neles há contido algo ainda significante e acessível, não como tautologia do mundo ${ }^{14}$, mas como reflexão profunda daquilo que ainda permeia a atualidade.

Os anseios que essas formas colocam em questão, talvez em formato mais atualizado em Tennessee do que em Tchékhov, permanecem como contínuos no contexto histórico, manifestando sinais de um sistema econômico e social que, em sua base, não sofreu mudanças tão significativas quanto se gostaria.

${ }^{12}$ LUKÁCS,G. 1965. p.149

Tradução:

Quanto mais as circunstâncias definem o homem, mais difícil este problema se torna, e mais a atmosfera parece absorver tudo para dentro de si. O homem, contornos definidos, não mais existem; só ar, só atmosfera. Tudo que a vida moderna introduziu através do enriquecimento das percepções e emoções parece desaparecer para dentro da atmosfera, e é a composição que sofre...

${ }^{13}$ O pesquisador Rodrigo Nascimento dedicou sua dissertação de mestrado ao tema de Tchékhov no Brasil. Mais informações a esse respeito podem ser encontradas lá. Cf. NASCIMENTO, Rodrigo Alves do. Tchékhov no Brasil: a construção de uma atualidade. São Paulo: 2013, 344f. Dissertação (Mestrado em Literatura e Cultura Russa) - Faculdade de Filosofia, Letras e Ciências Humanas, Universidade de São Paulo.

${ }^{14}$ ADORNO apud. COSTA, I. C. Sinta o Drama. Petrópolis: Editora Vozes, 1998. p.52. 
Pesquisar tais temas parece pertinente por oferecer um vislumbre de questões que ainda são contemporâneas e que podem, talvez, iluminar caminhos outros para um futuro que, como coloca Gumbrecht ${ }^{15}$, é cada vez mais desconhecido e ameaçador. Em vista das análises dos estudiosos que mais marcaram presença no trabalho, torna-se clara a perspectiva de que esses dramas ainda nos dizem respeito, não obstante sua beleza e poesia.

${ }^{15}$ GUMBRECHT, H.U. 2014. 


\section{O Jardim das Cerejeiras, Lady of Larkspur Lotion e A Strangest Kind of Romance: textos em diálogo}

Yet, somehow, within the space of a few years, Chekhov managed to bring together elements that created, to paraphrase Maxim Gorky, a new kind of drama, which heightened reality to a point in which it turned into a profoundly inspired symbol.

SENELICK, $L^{16}$

Qualquer livro de dramaturgia consultado trará sobre Tchékhov alguma variação do explicitado na epígrafe: com ele surgiu um novo tipo de drama. A obra dramatúrgica do escritor russo, de fato, problematizou muitos dos parâmetros até então estabelecidos a respeito do que seria uma boa peça de teatro, ampliando os horizontes de representação e encenação. Tal ampliação, cabe constatar, não foi feita por meio do abandono de certos preceitos do realismo, como um afastamento da forma mimética do teatro; ela foi, sim, uma forma de representar outros aspectos da realidade, agora percebida sob novos olhares.

Na evolução histórica das formas artísticas, fica claro como as formas de representação mudam de acordo com os preceitos de época que regem a própria percepção da realidade e, também, como o recorte representado revela muito desses mesmos preceitos, como se a temática fosse, de certa forma, já dada pelas questões suscitadas por um período histórico. O livro do crítico Anatol Rosenfeld,

\footnotetext{
${ }^{16}$ SENELICK, Laurence.The Complete Plays of Anton Tchekhov. New York: Norton \& Company, 2006. p. Xlvii Tradução:

No entanto, de alguma maneira, no espaço de alguns poucos anos, Tchékhov conseguiu juntar elementos que criaram, para parafrasear Górki, um novo tipo de drama, que elevou a realidade ao ponto de transformá-la em um símbolo profundamente inspirado.
} 
Teatro Épico ${ }^{17}$, esclarece tal relação ao tratar das discussões entre Goethe e Schiller sobre os gêneros literários:

\begin{abstract}
Nota-se, pois, uma perfeita intuição do fato de que os gêneros, e, mais de perto, a pureza estilística com que se apresentam, devem ser relacionados com a história e as transformações daí decorrentes. Ambos os poetas [Goethe e Schiller] reconhecem o fato de que - na expressão de G. Lukács - "as formas dos gêneros não são arbitrárias. Emanam, ao contrário, em cada caso, da determinação concreta do respectivo estado social e histórico. Seu caráter e peculiaridade são determinados pela maior ou menor capacidade de exprimir os traços essenciais de dada fase histórica." (Introdução à Aesthetik de Hegel. Op. Cit., pág.21). Talvez se diria melhor que o uso específico dos gêneros - a sua mistura, os traços estilísticos com que se apresentam (por exemplo, o gênero dramático com forte cunho épico) - adapta-se em grande medida à situação histórica-social e, concomitantemente, à temática proposta por respectiva época. ${ }^{18}$
\end{abstract}

A partir de tal perspectiva, pode-se supor que para o desenvolvimento de uma nova forma dramática algo no mundo objetivo deveria estar mudando. A dramaturgia de Tchékhov, que P. Szondi utilizou como um dos exemplos para ilustrar a crise do drama ${ }^{19}$, aponta para uma época de mudanças, cujas exigências sobre o conteúdo encaminharam a uma revolução formal, ao ponto de negar formalmente os dois pilares fundamentais do drama absoluto ${ }^{20}$ : o diálogo e a ação.

Dando procedência a esse mesmo raciocínio, pode-se imaginar que a retomada de alguns desses recursos tchekhovianos por um dramaturgo americano do século XX aponte para o surgimento de questões análogas em sua realidade histórico-social, que determinariam suas escolhas temáticas. As analogias históricas serão analisadas com mais detalhes no próximo capítulo, mas, antes, a análise recai nas soluções formais que ambos encontraram para os temas que "escolheram" tratar, tendo como base a peça $O$ Jardim das Cerejeiras, de Anton P. Tchékhov, e A Strangest Kind of Romance e Lady of Larkspur Lotion, duas peças em um ato, de Tennessee Williams.

Para se compreender as mudanças efetuadas na arte dramática pela dramaturgia de Tchékhov - que depois reapareceriam em Tennessee Williams -, é indispensável entender o que caracterizava o drama que o antecedeu.

\footnotetext{
${ }^{17}$ ROSENFELD, Anatol. O Teatro Épico. 2a Edição. São Paulo: Perspectiva, 2011.

${ }^{18}$ ROSENFELD, A. 2011. p.32.

${ }^{19}$ SZONDI, P. 2012. Idem.

20 Termo utilizado por Rosenfeld, equivalente, de maneira geral, ao chamado drama burguês, de P. Szondi
} 
Anatol Rosenfeld, na abertura do capítulo no qual trata a questão dos gêneros literários, afirma: “A maneira pela qual é comunicado o mundo imaginário pressupõe certa atitude em face deste mundo ou, contrariamente, a atitude exprime-se em certa maneira de comunicar"21.

Partindo do mesmo pressuposto, Peter Szondi $^{22}$ questiona as diversas teorias dramáticas que consagraram a forma absoluta do drama, alertando que para elas não existia um entendimento dialético da relação entre forma e conteúdo, de modo que se acreditava que as rígidas leis da dramaturgia eram, sim, atemporais. É um entendimento bastante moderno esse, que propõe que o formato reage intrinsecamente ao conteúdo escolhido e que ambos se produzem dentro de um contexto histórico-social que lhes define. Arnold Hauser, em seu livro The Sociology of Art $^{23}$, considera que o teatro moderno se distingue do teatro burguês - aquele das operetas, dos vaudevilles, dos melodramas e da pièce bien faite - por partir de um pressuposto diferente daquilo que compõe o teatro: "Since the last century in any case, the drama which became ever more productive in the literary sense has been looking for a stage appropriate to its manifold ideas and problems and not the other way around, the theatre looking for suitable material to produce" 24 . Desta maneira, tem-se que o teatro moderno teria se emancipado da rigidez da forma, agora "submetida" à preponderância do conteúdo.

É importante, no entanto, perceber que a preponderância do conteúdo, seu berço na própria conjuntura social e histórica que lhe dá origem e mesmo as técnicas formais que ganham cena, não são escolhas absolutamente conscientes. O lugar que ocupa a arte na estrutura do mundo, seu habitus - para utilizar o termo de Bourdieu ${ }^{25}$-, define em grande medida muitas de suas características, quer seja moldando seu horizonte de expectativas e possibilidades formais e subjetivas, quer seja por meio

${ }^{21}$ ROSENFELD, A. Texto/Contexto I. São Paulo: Perspectiva, 2006. p.17.

${ }^{22}$ SZONDI, P. 2004.

23 HAUSER, A. The Sociology of Art. Edição para Kindle. New York: Routledge, 1982.

${ }^{24}$ HAUSER, A. 1982. p.494.

Tradução:

De qualquer forma, desde o último século, o drama que tem sido cada vez mais produtivo no sentido literário tem procurado por um palco apropriado para a sua vasta gama de ideias e problemas, e não o contrário, o teatro procurando material que sirva para ser produzido.

${ }^{25}$ BOURDIEU, Pierre; "Campo do Poder, Campo Intelectual e Habitus de Classe"; A Economia das trocas Simbólicas; São Paulo: Ed. Perspectiva, 1974. 
da formação histórica e cultural que os artistas possuem.

As regras para a composição dramatúrgica tradicional, o chamado drama absoluto, então podem ser entendidas como representantes de uma determinada maneira de enxergar a realidade, determinada por essa mesma realidade em seu aspecto total. No caso do drama burguês, sua forma rígida vincula-se essencialmente a uma ideologia que ganhava espaço no momento de seu surgimento. A crise do drama, que Szondi situa como o início do drama moderno, nada mais seria do que o confronto entre um formato que se acreditava atemporal e a-histórico, regido por interesses de classe específicos, e a nova realidade moderna, que ali não encontrava meios de se representar. Para corroborar tal afirmação, Szondi se utiliza da dramaturgia de diversos autores modernos, mostrando como, a cada tentativa de alargamento temático, a forma absoluta do drama oferecia resistências e, prevalecendo o tema, se diluía e modificava. De maneira similar, Rosenfeld evidencia a necessidade de utilização de recursos épicos e líricos pela forma dramática para que esta conseguisse absorver o novo universo de significação apresentado pelos tempos modernos.

Nessa nova incursão do drama para áreas além do seu próprio gênero, é possível identificar também uma ampliação naquilo que se considerava a linguagem teatral. O século XIX assistiu à lenta ascensão do encenador, passou-se a incorporar na própria concepção da peça elementos outros, orquestrados por essa nova figura, que se distanciavam do diálogo. Essa ampliação, impulsionada em certo grau pela exigência que o texto dramatúrgico impunha à encenação, se desdobrou de forma a ampliar as possibilidades de criação do signo teatral, que não mais vinculava somente a enunciação e gestos ao conteúdo, mas também elementos "de atmosfera", como sons, cenários, silêncios, figurinos etc., que ganhavam função significante. Ao nível básico de comunicação de sentido do teatro, intrinsecamente vinculado ao enredo, do drama clássico ${ }^{26}$, foi adicionada uma série de outros níveis, inclusive o simbólico e o metafórico, libertando o fazer teatral do mimetismo simplificado visto até então e possibilitando a representação de teias mais complexas de ideias.

Como arte, a forma dramática se vê em grau de vantagem em relação às demais por contemplar em sua forma potencial infinitas vias de mediação de conteúdo - palavra aqui utilizada em seu sentido mais amplo e genérico - desde o texto dramatúrgico em si, cujo meio é a palavra escrita, até o vazio absoluto de um palco, que, pela ausência e silêncio - ou seja, em seu caráter negativo - também consegue se expressar. Nesse sentido, a dramaturgia tchekhoviana representa um passo a mais rumo à

${ }^{26}$ Chamamos de drama clássico a dramaturgia que antecede o drama burguês e a crise do drama, seguindo a terminologia apresentada por Lukács. 
exploração desse potencial, enquanto o drama absoluto em seu ideal apresenta-se como claro limite.

A forma dramática tradicional teve seu início, segundo Szondi, na Renascença,

"Como audácia espiritual do homem que dava conta de si com o esfacelamento da imagem medieval do mundo, ele construía a efetividade da obra na qual pretendia se firmar e espelhar partindo unicamente da reprodução da relação entre homens." ${ }^{27}$.

A forma eleita para sua expressão, então, colocava o homem em seu centro, que ganhava realidade dramática no ato de decidir-se, deixando aparecer o mundo somente no momento em que este a ele se referisse. Esse antropocentrismo, muito influenciado pelo pensamento de Descartes, encontrou suas formas na arte dramática, fazendo de sua estrutura fixa meio inconteste de reafirmação dos valores a ele relacionados. Desta forma, era a partir do sujeito que se erguiam todos os demais recursos da dramaturgia.

Szondi afirma que o drama clássico, do qual deriva o drama burguês do século XVIII e XIX, tinha como tema unicamente o mundo das relações inter-humanas, ou intersubjetivas, de modo que a ação dramática dependia tão somente das personagens e suas relações. Como centro propagador da ação, cabia às personagens algumas características, como, por exemplo, serem livres para efetuar escolhas, assim determinando o percurso de suas histórias. Os determinismos históricos, de classe ou de gênero, não encontravam substrato em tal formato, pois impediam que o drama se desenrolasse ou exigiam a utilização de expedientes épicos. Outra consequência formal que dali surgia era a importância do diálogo como mecanismo de representação.

"Era o diálogo, no entanto, o meio que dava expressão linguística a esse mundo inter-humano. Depois de eliminados prólogo, coro e epílogo, ele se tornou no Renascimento, talvez pela primeira vez na história do teatro, o único componente do tecido dramático (...)."28.

Se o único meio de comunicação de uma peça era o diálogo, não cabia em tal formato qualquer tema exterior às relações inter-humanas, limitando a esfera de significações possíveis dentro do

${ }^{27}$ SZONDI, P. 2012. p.,23.

${ }^{28}$ SZONDI, P. 2012. p.24. 
drama. Por outro lado, como elemento propulsor da ação, o diálogo deveria sempre fazer referência àquilo que estava por vir na peça, para impedir sua estagnação. Não mais havendo narrador ou sujeito lírico, como aponta Rosenfeld ${ }^{29}$, a função de manter a obra em andamento recaía inteiramente sobre as personagens e aquilo que enunciavam. O formato dialógico, então, deveria ser necessariamente construído a partir de afirmações e réplicas, através das quais surgiria em cena um conflito - dado que este não poderia ter outra origem senão na esfera do intersubjetivo.

Outra característica que Rosenfeld e Szondi apontam é a exigência temporal da dramática, a necessidade de ali representar uma sucessão de presentes, organizada pela mais rígida causalidade. Além disso, por sua articulação rumo ao desenvolvimento da ação, o tempo presente em questão era sempre aquele que engendra o futuro ${ }^{30}$. Embora existisse a possibilidade da utilização de recursos épico-narrativos na peça, o desvio para outros tempos implicava em uma quebra da ação dramática, que deveria ser única e absoluta. Mesmo no caso de dramas históricos, o tempo era o do presente, e a ação era primária, como se ali acontecesse pela primeira vez.

A preocupação com as unidades de ação e tempo, provenientes das categorias estabelecidas por Platão e Aristóteles, objetivava a criação de um certo ilusionismo em cena, que permitisse à mensagem - no geral, moral - absoluta centralidade. Rosenfeld, em sua teoria dos gêneros ${ }^{31}$, afirma que, sendo a ausência de um mediador (eu-lírico, como na lírica, e narrador, como na épica) uma das características determinantes do gênero dramático, tornava-se necessária a unidade de tempo, de espaço e de ação, caso contrário, tornar-se-ia evidente a função de um mediador que organizasse as escolhas e as quebras, extrapolando os limites do drama absoluto. No mais, a peça dramática se articularia em torno de uma ação única, que se desenvolveria por meio de um enredo causalmente amarrado em si mesmo, cuja manifestação seria realizada pelas personagens. Desta maneira, com todos os elementos postos em função da ação e colaborando para sua realização, desapareceria por completo a necessidade de mediação.

Os limites impostos pela forma rígida do drama às suas possibilidades temáticas são inúmeros. Negada a utilização de recursos épicos e líricos, cabia a representação somente daquilo que poderia

\footnotetext{
${ }^{29}$ ROSENFELD, A. 2011. Idem.

${ }^{30}$ COSTA, I.C. 1998. p.57.

${ }^{31}$ ROSENFELD, A. 2006.
} 
ser apresentado no palco através de diálogos ${ }^{32}$. As ações das personagens, então, só poderiam ser motivadas por suas próprias subjetividades ou pela interação delas com as das demais personagens presentes ou, mais ainda, só poderiam ser motivações contidas nessa série de presentes articulados que cabiam no tempo determinado da peça. A realidade ali representada, assim, tomava formas bastante simplificadas; por seu caráter absoluto, a obra dramática isolava-se da realidade histórica, fechando-se em si mesma.

Tendo em vista as convenções do gênero dramático, sumariamente explicadas acima, pode-se vislumbrar a dificuldade que um escritor encontraria ao tentar aplicar tal forma a conteúdos que não lhe fossem previstos. Se antes a representação tinha como objetivo reafirmar a liberdade do novo homem (um modelo ideal do homem burguês), que se descobria dono de seu próprio destino através de seu poder de raciocínio e agência, a tentativa de adequar tal forma a um conteúdo diametralmente inverso levaria, sem dúvida, a uma série de problemas. Tanto Szondi quanto Rosenfeld nos apresenta, ao iniciar as discussões sobre o teatro moderno, um mundo em convulsões, profundamente desiludido com as crenças que até então o havia guiado. Após a Revolução Industrial, com o crescimento das grandes cidades e a entrada massiva do modus operandi do capitalismo industrial, a realidade provou errada a premissa primeira do drama burguês. O homem, como sujeito atuante sobre suas circunstâncias, descobriu-se ser verdadeira exceção, enquanto a grande massa de indivíduos descobria que sua liberdade era mínima. Perante essa nova posição do homem, cabe dizer, um fenômeno curioso ocorre com a estrutura geral da peça: a percepção aguçada da importância da situação geral, ou do milieu, para usar as palavras de Lukács $^{33}$, passa a funcionar como elemento dramático.

Prosseguindo no percurso de Anatol Rosenfeld, encontram-se em Woyzeck (1837), peça do dramaturgo alemão George Buchner, os primeiros sinais daquilo que Szondi chamou de a crise do drama. Nessa peça, o protagonista, cujo nome dá título à obra, é apresentado como espécie de títere nas mãos das circunstâncias sociais às quais pertence. Como soldado de baixíssimo escalão, recai

\footnotetext{
${ }^{32}$ É bastante ilustrativo o exemplo que P. Szondi oferece sobre o tema: A tentativa de levar ao palco 'Lutero, o reformador' implica a referência histórica. Se fosse possível mostrar Lutero tomando a decisão de reformar a fé em uma situação inteiramente dramática, estaria criado o drama da Reforma. Mas aqui surge uma segunda dificuldade: as condições objetivas que motivaram tal decisão exigem um tratamento épico. Para o drama, a única explicação possível para a decisão de Lutero extrairia seus motivos da situação inter-humana vivida por ele, solução evidentemente estranha às intenções de uma peça sobre a Reforma.
}

SZONDI, P. 2012. p. 27.

${ }^{33}$ LUKÁCS, G. 1965. p. 155. 
sobre ele uma série de exigências impostas por sua realidade objetiva, sobre as quais não tem opções de escolha; são exigências que determinam sua sobrevivência. Já então vê-se ruir o substrato do drama absoluto, uma vez que, amarrado, o personagem é incapaz de desencadear ações ele mesmo, sendo circunstancialmente levado a executar seus atos. Rosenfeld assinala nesta obra pressupostos que marcam sua época histórica e que encontram eco em quase toda a dramaturgia do século XIX e início do XX, de forma que muitos dos recursos utilizados por Büchner apareceriam de maneiras mais ou menos similares nas obras que se seguiram.

São três os principais elementos que destaca em Woyzeck: o retrato de um protagonista não livre, a quebra com a forma dialógica - o esvaziamento dos diálogos - e a quebra com a sequência causal das cenas. É importante notar como esses três elementos se interligam, um justificando o outro dentro do rol de soluções dramáticas que o escritor encontrou. Se o personagem é incapaz de decidir-se, a ação dramática é necessariamente modificada, sendo necessário que encontre outra origem. A quebra com o dialogismo também corrobora a impossibilidade de agência da personagem, já não há atos para anunciar através dos diálogos. Assim, o mecanismo por meio do qual se move o drama, seu princípio de ação, é modificado inteiramente e as cenas deixam de desencadear umas às outras, cabendo ao autor encontrar outro meio de fazer mover a peça.

\footnotetext{
"Cada cena, ao invés de funcionar como elo de uma ação linear, representa um momento em si substancial, que encerra toda a situação dramática ou, melhor, variados aspectos do mesmo tema central - o desamparo do homem num mundo absurdo."34.
}

Embora a unidade de ação se perca, a totalidade da peça se mantém, baseada agora no protagonista, presente em todas as cenas, na atmosfera e também na situação dramática.

É imprescindível atentar às significativas mudanças possibilitadas pela substituição da ação pela situação dramática, agora responsável não só pela unidade da peça, mas também o elemento através do qual, por sua oposição ao sujeito, tem origem o novo tipo de conflito do drama moderno. Além disso, como mecanismo dramático, esse novo expediente permite a inclusão de referências que extrapolam o âmbito restrito do drama absoluto e os limites das relações intersubjetivas, aproximando-o da forma épica.

${ }^{34}$ ROSENFELD, A. 2011.p. 80 
Frente ao exemplo da breve análise de Woyzeck, a citação de Arnold Hauser faz-se mais clara, pois a peça evidencia uma mudança sobre as motivações do gênero teatral. Se anteriormente o conteúdo havia de ser cerceado pelas regras do drama clássico, a partir de Büchner a forma se torna tematicamente motivada. Na transição entre o drama clássico e o drama moderno, afirma Szondi, o tema preponderante sempre se cristaliza em forma.

A crise do drama está contida exatamente nesse embate entre o modelo dramático consagrado, que implica conteúdos que estejam previstos na forma, e a nova gama de interesses de representação, proveniente de uma nova realidade e sua consequente visão ontológica. Ibsen, Hauptman, Maeterlinck, Strindberg e Tchékhov são dramaturgos que se confrontaram com esse dilema, tentando adaptar os modelos existentes às temáticas visadas por suas épocas. Nesse percurso, no entanto, o modelo burguês não desaparece, pode-se percebê-lo como referência formal em muitas críticas feitas ao teatro desde então. Da crise do drama não resultam vencedores e perdedores, mas um alargamento nas possibilidades de encenação e, por conseguinte, de percepção do próprio gênero.

Os teóricos citados acima dedicam parte de suas obras à análise da dramaturgia tchekhoviana, tomando o escritor como um dos maiores e mais influentes dramaturgos da época moderna. De fato, as inovações dramáticas que o autor russo introduziu no palco foram de alto alcance e ampliaram de maneira substancial o potencial do fazer teatral ${ }^{35}$. Não à toa, suas peças longas foram recebidas com alguma resistência, sendo sua trajetória marcada por pesarosos fracassos. Como assinala Rosenfeld ${ }^{36}$, a arte dramática como gênero literário é incompleta, encontrando concretude somente através do palco e da encenação. O que se vê na dramaturgia tchekhoviana e, mais tarde, com sua encenação no Teatro de Arte de Moscou (TAM), é a utilização de novos recursos, desde sempre disponíveis para o teatro, mas subutilizados em razão da rigidez do drama absoluto. Como se explorando em sua totalidade potencial a linguagem teatral, o dramaturgo se utilizará de seus mais diversos elementos, emancipando-se do reino restrito da palavra. Em vista do modelo clássico do teatro, pode-se avaliar com maior precisão as rupturas formais de sua escrita e, para isso, a base da análise será a peça $O$ Jardim das Cerejeiras ${ }^{37}$.

35 É importante, porém, notar como alguns destes recursos não eram de todo novos dentro do teatro russo, o esvaziamento do diálogo, por exemplo, pode ser facilmente encontrado em Gógol, como também a utilização de expedientes cômicos, os quais serão tratados com maior detalhamento mais adiante.

${ }^{36}$ ROSENFELD, A. 2011. 
A fábula sumarizada da peça não apresenta evidentes inovações, o próprio tema da aristocracia em decadência estava bastante em voga, encontrado em diversas outras obras do período ${ }^{38}$. O que há de realmente novo em Tchékhov é a forma que adota para manifestar tal conteúdo e sua centralidade como um dos elementos que garantem a unidade da peça - para além das histórias individuais, como seria no drama absoluto. A fábula de $O$ Jardim das Cerejeiras consiste na história de uma família da nobreza decadente que terá sua propriedade leiloada para quitar diversas dívidas. A proprietária, Liubov Andreievna Raniévskaia ${ }^{39}$, retorna de Paris com sua filha Ânia, seu criado Iacha e Carlota, a governanta, para tentar reverter o processo; a casa e, em especial, o jardim de cerejeiras, eram da família já há muitas gerações, de modo que reservam certo apelo nostálgico e saudosista, e a protagonista com eles se relaciona de maneira bastante emocional. Durante seu refúgio no estrangeiro, ocasionado pela morte de seu filho, quem ficou a encargo da casa foi sua enteada, Vária, filha de seu primeiro marido, um advogado já falecido. Além dela, cuidavam da casa Firs, um velho criado, Epikhodov, seu contador e Duniacha, uma empregada.

Ao chegar de Paris, Raniévskaia reencontra também seu irmão Gáiev, Lopákhin, um homem de negócios e filho de antigos servos da propriedade, Trofímov, um estudante que havia sido tutor de seu falecido filho, e também um vizinho nobre proprietário, Simeonov-Píshchik. Desde logo, chama atenção a imensa quantidade de personagens; o drama tradicional contava com poucos personagens, hierarquicamente organizados entre os protagonistas e alguns personagens auxiliares superficialmente

37 TCHÉKHOV, Anton Pavlovitch. O Jardim das Cerejeiras seguido de Tio Vânia. Tradução: Millôr Fernandes. Porto Alegre: L\&PM, 2014.

38 By 1900 there were a lot of works about uprooted gentry and estates confiscated by arrivistes. Pyotr Nezhevin's Second Youth (1883), a popular melodrama dealing with the breakup of a nest of gentry, held the stage until the Revolution, and Chekhov had seen it. That same year Nikolai Solovyov's Liquidation appeared, in which an estate is saved by a rich peasant marrying the daughter of the family. Chekhov would not have been raking over theses burn-out themes if he did not have a fresh angle on them.

Tradução:

Até 1900, havia muitas obras sobre a pequena nobreza desenraizada e propriedades confiscadas pelos arrivistes [termo francês, semelhante ao conceito de novo rico]. Segunda Juventude (1883) de Piotr Nezhevin, um melodrama popular cujo tema era a dissolução de um ninho da pequena nobreza, prendeu os palcos até a Revolução, e Tchékhov o havia assistido. No mesmo ano, Liquidação, de Nikolai Solovióv, apareceu, na qual uma propriedade é salvo por um rico camponês que esposa a filha da família. Tchékhov não estaria se debruçando sobre esses velhos temas se ele não tivesse um ângulo inovador sobre eles.

SENELICK, L.2010.p. 973.

${ }^{39}$ Nas diferentes traduções utilizadas, os nomes das personagens aparecem de maneiras diferentes. Liubov Andreievna Raniévskaia é às vezes chamada de Líuba ou Liubov Andreievna. Leonid Andreievitch Gáiev, é às vezes chamado pelo primeiro nome ou somente pelo sobrenome. O mesmo ocorre com as demais personagens. Nas citações, as variações de grafia se devem à utilização de traduções diferentes. 
caracterizados. No caso tchekhoviano, a hierarquia é amenizada pelo aprofundamento subjetivo de todos os integrantes da peça, aproximando a importância que todos têm dentro da estrutura. É certo que alguns personagens ganham mais centralidade do que outros, porém, isso já não os obriga a serem elementos superficiais ou rasos.

As diversas subtramas que permeiam o texto, como amor entre Iacha, Duniacha e Epikhodov, ou entre Trofímov e Ânia, Lopákhin e Vária, e Raniévskaia e seu amante francês, não recebem atenção, a não ser como fatos corriqueiros que ilustram a estagnação e o isolamento das personagens. De certa maneira, essas pequenas historietas, como também a própria venda do jardim, surgem como fios que compõem o grande tecido que é a obra em sua totalidade, de modo que nenhuma se destaca enfaticamente do todo, funcionando juntas para compor algo muito maior do que sua somatória.

O nivelamento das diversas tramas e subtramas enfatiza que não há acontecimentos dramáticos; no primeiro ato, a família se reencontra na casa, junto aos amigos; no segundo, conversam e convivem; no terceiro, há uma festa na propriedade, durante a qual o leilão ocorre, fora de cena, e descobre-se a venda do jardim; no quarto e último ato, Lopákhin surge como o comprador, e a família desocupa a casa. Como se vê, a própria venda do jardim, que poderia ser o clímax na peça, perde seu impacto como tal, estando inserida de maneira pouco enfática.

Já pela sucinta descrição do que ocorre em cada um dos atos, percebe-se quão diferente é sua estrutura daquilo que era esperado de uma peça convencional. Os atos se diluem no tempo (a peça se passa de maio a agosto), quebrando com a rígida causalidade da ação, pois já não se trata de "presentes-que-engendram-futuros ${ }^{40 ",}$, distantes como são colocados. A criação de tensão também é impossibilitada, e, sem tensão, desaparece a possibilidade de um desfecho dramático. Como afirma Bitsilli $^{4142}$, Tchékhov termina as peças com finais zero, de modo a tornar ainda mais claras as discrepâncias entre o esperado e aquilo que de fato ocorre, aprofundando o caráter anedótico de suas peças. Por mais que a propriedade seja vendida, nenhuma das questões ali expostas, como a não identidade de Charlota ou o pedido de casamento de Epikhódov a Duniacha, se resolve. Como na vida, as coisas ali simplesmente acontecem, tomando um curso natural e tranquilo, similar ao que Schiller descreve sobre o poema épico:

\footnotetext{
${ }^{40}$ COSTA, I.C. 1998.

${ }^{41}$ BITSILLI, P. From Chekhonte to Chekhov.In.: ERLICH, Victor (Org.). Twentieth -Century Russian Literary Criticism. New Haven: Yale University Press, 1975. p.212.
} 
Na sua discussão, Goethe e Schiller verificam 'que a autonomia das partes constitui caráter essencial do poema épico', isto é, não se exige dele o encadeamento rigoroso do drama puro; o poema épico 'descreve-nos apenas a existência e o atuar tranquilo das coisas segundo suas próprias naturezas, seu fim repousa desde logo em cada ponto do seu movimento; por isso não corremos impacientes para um alvo, mas demoramo-nos com amor a cada passo...' (Schiller). Tal observação sugere que a Épica, além de narrar ações (manifestando-se sobre elas, em vez de apresentá-las como o drama), se debruça em ampla medida sobre situações e estados de coisas. Contrariamente, no drama cada cena é apenas elo, tendo seu valor funcional apenas no todo $^{43}$.

Mais uma vez, as mudanças pelas quais passa a forma dramática apontam para a incorporação de elementos épicos; mesmo a distribuição e o peso dos personagens e de suas histórias se dão de modo análogo àquele descrito por Schiller. $\mathrm{O}$ que se percebe é uma visão que se assemelha em muito àquela proposta pelos romances realistas que ganhavam força desde o século XVIII. A diluição da força de cada uma das subtramas - e mesmo da trama "central" - em um grande retrato será uma das características principais dessa emancipação formal resultante da crise do drama. Como recortes situacionais, as cenas dentro desse novo formato possuem caráter quase independente, contrastadas com a antiga relação causal do conflito e o desenvolvimento das ações, tornando-se partes que corroboram um argumento central, mas do qual este não depende necessariamente.

É a situação geral que importa à peça, e é por meio dela que o mecanismo dramático se move, pois mesmo que as cenas, sim, sugiram um porvir encadeado, não reside nisso sua movimentação, como também não reside nos diálogos, que de maneira geral nada nos dizem. Todos esses elementos, como já dissera Lukács $^{44}$, são absorvidos pela atmosfera e pela situação geral da peça, reiterando a existência condicionada de seus sujeitos.

Como muitos teóricos já explicitaram, vê-se na dramaturgia tchekhovianao esvaziamento do diálogo que, por mais que permaneça como forma (aparentes afirmações e réplicas), perde sua função comunicativa e, assim, sua função como propulsor da ação. Os personagens, de maneira geral, são incapazes de se comunicar uns com os outros, suas falas são constantemente interrompidas por silêncios, gestos, recriminações ou indiferença.

\footnotetext{
${ }^{43}$ ROSENFELD, A. 2012. p. 32

${ }^{44}$ LUKÁCS, G. 1965. Idem.
} 
DUNIACHA: Epikhodov, o contador, pediu minha mão na Páscoa!

ÁNIA: Sempre a mesma história... (Alisa o cabelo.) Perdi todos os grampos... (Mal se sustenta em pé, de cansaço...)

DUNIACHA: Não sei o que pensar... Ele me ama, está muito apaixonado.

ÁNIA (Olha para a porta, com voz enternecida.): O meu quartinho, a minha janelinha. Como se nem os tivesse deixado... finalmente estou aqui de novo... em casa!... Amanhã acordo bem cedo e corro para o jardim... (.... $)^{45}$

O que se vê em cena são seres na mais absoluta solidão, embora convivendo aparentemente bem entre si. A incomunicabilidade surge diante do leitor como barreira intransponível para as personagens, que falam umas às outras sem escutar e sem entender o que está sendo dito, como se a mundos de distância. O que Tchékhov parece explicitar é uma falha da própria linguagem, que ao ser enunciada por um sujeito perde totalmente sua capacidade de significação ao chegar aos ouvidos do outro.

LOPÁKHIN: Seu irmão, Leonid Andrêievitch, diz que eu sou um camponês, um sujeito bronco. Para mim tanto faz. Ele pode falar... O que importa é que eu continuo merecendo a confiança da senhora, como antigamente... e que se digne olhar para mim com esses olhos assombrosos... como antigamente!... Oh, Deus! Meu paizinho foi outrora servo de seu digno paizinho e avô. Mas a senhora me fez um bem tão grande que eu esqueci tudo e gosto da senhora do fundo da alma, como a uma irmã... Mais que uma irmã...

LIUBOV ANDREIEVNA: Não sei o que está acontecendo comigo, mas não consigo ficar sentada. (Levanta-se de um salto e anda de um lado para o outro, muito excitada.) Não sei se poderei sobreviver a esta sensação de felicidade... Está bem, está bem, vocês podem rir dessa bobagem... meu velho armário querido!... (Beija o armário) Minha velha mesinha querida!

\section{$(\ldots)^{46}$}

${ }^{45}$ TCHÉKHOV, Anton Pavlovitch. Teatro II - As Três Irmãs e O jardim das Cerejeiras. Tradução: Gabor Aranyi. Mairiporã: Editora Veredas, 2013. p.72.

${ }^{46}$ TCHÉKHOV, A.P. 2013.p.76-77. 
LIUBA: fique mais um pouco, eu lhe rogo. Quando você está conosco pelo menos é mais divertido. (Pausa) Vivo sob o terror de alguma coisa, como se a casa fosse me desabar em cima.

GAIÉV: Tabela na branca, encaçapa a dois... errou!

LIUBA: Estamos pagando por todos os nossos pegados.

LOPÁKHIN: Pecados, a senhora?

GAIÉV: (Põe um caramelo na boca)? Pecado é o meu, que chupei minha fortuna em caramelos. $(R i$.

LIUBA: Quantos pecados! Joguei todo o meu dinheiro fora, como uma louca. Casei com um homem que só uma coisa sabia fazer bem - dívidas. Morreu de champanhe - bebeu até o fim. ${ }^{47}$

Como recurso dramatúrgico, os diálogos sem alcance parecem comunicar-se somente com o espectador (sem dirigir-se a ele), transformando sua função: identificam-se neles os traços de caráter, os desejos e as emoções dos personagens, muito embora estes sejam frequentemente traídos por seus gestos ou por seus silêncios. Novamente, contrastada com a forma do drama absoluto, no qual a esfera inter-humana era o único tema, a incomunicabilidade aponta para outra esfera, a da situação, e o conflito passa a se fazer a partir das tensões criadas entre a situação geral e a subjetividade das personagens evidenciadas pelos diálogos.

Desde logo, é apresentado um recorte bastante específico, uma situação dramática que desencadeia toda a peça. O conflito está dado já no primeiro ato, a situação paradoxal na qual se encontram as personagens que, tendo evitado o "vulgar" mundo do dinheiro, agora precisam adentrá-lo ou perder tudo que têm; o conflito ganha contornos interiorizados, existindo agora somente como um embate entre a subjetividade das personagens e um mundo sobre o qual não têm poder de ação. Não há espaço para a escolha, que só seria possível se houvesse a premissa de que tais personagens são livres e atuantes. A incomunicabilidade se estende, então, para além da esfera de relações interpersonagens e dos diálogos, condicionando também a posição que ocupam perante o mundo, como se, distantes

${ }^{47}$ TCHÉKHOV, Anton Pavlovitch. O Jardim das Cerejeiras seguido de Tio Vânia. Tradução: Millôr Fernandes. Porto Alegre: L\&PM, 2014. p.40-41. 
deste, não reconhecem a própria situação na qual se encontram e, assim, permanecem em total estagnação, incapazes de atuar. A estrutura da peça faz com que a perda do jardim seja inevitável desde o início. Condicionadas por elementos externos, não há nada que as personagens possam fazer para mudar seus destinos, e a situação dramática se desenvolve de modo quase independente delas.

Embora possíveis soluções aos problemas se apresentem, no universo da peça, elas são sempre excluídas. Está previsto pela própria forma adotada que nada poderá ser mudado, pois as personagens não têm poder de agência, e o motor propulsor é a situação. Isso pode ser percebido nos inúmeros conselhos dados a Raniévskaia por Lopákhin que, representativo do mundo de negócios, consegue avaliar as possíveis saídas para o problema. Porém, a linguagem falha novamente em sua função, e as palavras de ajuda são incapazes de iluminar uma saída.

É importante notar que o texto tchekhoviano, desprovido de enredos marcantes que vinculem suas partes, ganha sentido e profundidade em seus detalhes; o todo se mantém por meio das menores partículas, que, uma a uma, agregam valor e sentido à totalidade. A recorrência de símbolos, por exemplo, que constantemente remetem ao tema central ou ao menos o corroboram, é uma forma de manter a unidade do drama, já que o seu centro não está mais na ação. Na peça em questão, talvez o mais identificável deles seja o próprio jardim, sobre o qual se projeta, por vezes, a sensação de nostalgia, de perda e de esperança na renovação, como na fala que se segue:

LIUBOV ANDREIEVNA (Olha pela janela): Oh, minha infância, minha pureza! Eu dormia neste quarto, daqui olhava o jardim. Toda manhã a felicidade acordava junto comigo, e o jardim continua igualzinho ao que era, não mudou nada! (Rindo de alegria) É tão majestosamente branco! Meu querido jardim! Nem o outono desbotado nem o inverno gelado conseguem maltratá-lo, você está jovem de novo e feliz, e não foi abandonado pelos anjos celestiais... Meu Deus, se eu pudesse ainda uma vez livrar os ombros dessa pesada pedra, se pudesse esquecer o passado!48

As inúmeras referências feitas ao jardim durante a peça corroboram as diversas interpretações, como se através dele pudesse ser melhor entendido o que se passa no interior das personagens, o que as move e o que as estagna. No último ato, após o jardim já ter sido vendido, seu significado é desmascarado como gigantesco peso arrastado pelas personagens:

${ }^{48}$ TCHÉKHOV, A.P. 2013. p.80. 
GAIEV (contente): De fato, agora está tudo bem. Enquanto não leiloaram o jardim das cerejeiras todos estávamos tão nervosos, tão infelizes... E agora, quando a questão está definida e não se pode mais mudá-la, de repente nos acalmamos e até sorrimos... Eu, por exemplo, tornei-me funcionário de um banco, um perfeito financista... Direto na caçapa! E você, Liuba, está também mais satisfeita, não há dúvida.

LIUBOV ANDREIEVNA: É verdade, meus nervos estão bem melhores. $(\ldots)^{49}$

Como se, agora que os destinos pessoais de todos estão selados, não houvesse mais motivo algum para a peça continuar; a situação inicial é desfeita, e cada personagem segue seu caminho, mais ou menos similar àqueles nos quais estavam antes do evento do jardim, um denouement ${ }^{50}$ em zero.

Diferentemente do drama rígido, cujos personagens, além de reduzidos, são tratados de maneira superficial, todas as personagens de Tchékhov são munidas de personalidades claramente delineadas e histórias próprias. A existência delas auxilia na criação da atmosfera total que fornece unidade à obra e é por meio delas que se delimita o novo tipo de conflito entre sujeito e mundo. Essas características evidenciam um novo mecanismo de desenvolvimento das peças, não mais baseado na ação e sua unidade; os textos tchekhovianos são compostos a partir de seus menores elementos. $\mathrm{O}$ desenvolvimento de detalhes, as diversas subtramas, os símbolos, os gestos, as personalidades, as referências externas, tudo ganha função significante dentro do quadro que se pretende apresentar. Vale lembrar novamente da descrição do gênero épico de Schiller ${ }^{51}$, em que a situação é comunicada a partir do livre fluir de seus diversos elementos, percebendo um alargamento do drama em direção ao épico.

Reside nisso, talvez, a maior inovação tchekhoviana perante o drama rígido, a vontade de transmitir através da forma dramática um conteúdo antes reservado à forma épica. Raymond Williams elucida melhor a questão:

\footnotetext{
${ }^{49}$ TCHÉKHOV, A.P. 2013..p.114.
}

${ }^{50} \mathrm{O}$ denouement, ou desenlace, era tradicionalmente o momento no qual o conflito do drama era resolvido, levando o protagonista à catarse ou à revelação, marcando o final da tensão para o público. Em Tchékhov, a modificação da estrutura do conflito e, consequentemente, a estrutura total da peça, implica na quebra com a forma do denouement tradicional, que perde suas características catárticas.

${ }^{51}$ Página 29 deste mesmo capítulo. 
Muito da descrição detalhada da atmosfera, do personagem, do olhar, dos gestos, do modo de falar vem de outra forma literária, o romance, em que esse tipo de descrição pode ser direta. (...) O que está em questão, numa peça como "A Gaivota", é se a atenção aos detalhes pode ser traduzida em termos dramáticos; ou, dizendo de modo mais difícil, se a concepção total da experiência, para a qual os detalhes contribuem, pode ser imaginada e escrita em forma de texto dramático. ${ }^{52}$

O alargamento da esfera temática possível ao drama torna-se, então, evidente. Embora possa ser argumentado que, visto de longe, o assunto do qual o escritor trata não é muito diferente daquele encontrado em obras que ainda seguem rigidamente as regras do drama clássico; o recorte por meio do qual escolhe tratar o tema e o próprio ângulo de visão que adota são substancialmente diferentes. O indivíduo perde seu espaço no drama tchekhoviano, pois permanece refém de uma série de constrições sobre as quais não tem nenhum controle, negando em essência a premissa primeira na qual se fundamenta o drama burguês. ${ }^{53}$ Incapaz de atuar e de se comunicar, o indivíduo é tragado pela totalidade da vida que o condiciona, muito similar à maneira como Woyzeck o é por suas circunstâncias. A ênfase, então, é dada à totalidade e não mais ao particular, permitindo, paradoxalmente, que as particularidades dos diversos elementos da peça se manifestem.

A riqueza de detalhes, no entanto, não se manifesta de forma estritamente realista. A composição de Tchékhov possui uma dimensão lírica e simbólica que permite que os detalhes agreguem sentido à situação geral. A característica atmosfera tchekhoviana tem nesse expediente sua origem, como também sua qualidade impressionista ${ }^{54}$. As impressões de isolamento, ineficácia, decadência e prostração que dão o tom da peça são sugeridas liricamente (lembrando que a função linguística da lírica é a da expressão), sem a necessidade de serem de fato enunciadas.

A análise contrastiva de $O$ Jardim das Cerejeiras com o formato típico do drama burguês e do melodrama traz à atenção outra importante característica: a ausência da dualidade entre o bem e o

${ }^{52}$ WILLIAMS, Raymond. Drama em Cena. Sâo Paulo: Cosac Naify, 2010. p.173.

${ }^{53}$ Como Trofímov, cuja rebeldia é incapaz de atingir o plano da ação concreta, a recusa de Vária de assumir seu amor por Lopákhin. Essa característica, no entanto, é geral à peças de Tchékhov, um de seus exemplos mais claros é Ivanov, da pela de mesmo título, que se caracteriza por essa extrema incapacidade para mover-se. É interessante notar, como será exposto no capítulo três, que essa característica de seus personagens seria recebida, a princípio, de maneira bastante negativa tanto pela crítica russa quanto pela americana.

${ }^{54}$ Rosenfeld argumenta que Tchékhov "levou o naturalismo às suas últimas consequências e à sua auto-superação num impressionismo em que todos os contornos se esgarçam na riqueza das nuanças."

ROSENFELD, A. 2011. p.91. 
mal. O teórico e diretor, Peter Brook ${ }^{55}$, enxerga na dramaturgia tchekhoviana aquilo que considera o ponto essencial do teatro, o necessário desaparecimento do ponto de vista pessoal do autor, como aquele presente no romance. Sobre essa qualidade de sua escrita, afirma Brook em sua comparação entre Shakespeare e Tchékhov:

(...) nesse ponto de vista comum: um ponto de vista múltiplo. Em ambos os casos, nenhum juízo é emitido sobre as personagens, cada um existe de maneira totalmente independente, o ator pode dar tanta densidade a um como a outro e, consequentemente, o espectador pode sair do maniqueísmo habitual: não há "bons" nem "maus". 56

A multiplicidade de pontos de vista ganha corpo por intermédio das personagens, como, por exemplo, Raniévskaia defende o ponto de vista aristocrático, Lopákhin, o do burguês em ascensão, Gáiev, o do homem supérfluo, Trofímov, o do eterno estudante, entre outros ${ }^{57}$. Essa característica corrobora, ainda, o argumento de Lukács ${ }^{58}$, que coloca o drama moderno sob o paradigma do movimento romântico, cujos pilares são o historicismo e o individualismo. A multiplicidade de pontos de vista e seu consequente relativismo atestam uma visão circunstancial do homem, impossibilitando uma posição de todo maniqueísta sobre seus atos. Expostos em sua complexidade, os personagens não se dão aos rótulos de positivos ou negativos, exprimindo fatores que se encaixam em ambos, como explicita V. Gottlieb em sua análise da comédia tchekhoviana:

With most of his characters, their three-dimensionality results in a 'realistic' perspective, with decent and weak aspects to each character, and no sense of the 'black and white' which informed the stereotypic characters and plots of many of the contemporary popular

\footnotetext{
${ }^{55}$ Peter Brook encenou O Jardim das Cerejeiras em 1981 e recebeu o Grand Prix Dominique de la mise em scéne. Sobre sua encenação Cf. PICON-VALLIN, B. O Jardim das cerejeiras, encenação de Peter Brook. In. Drama em cena. São Paulo: Perspectiva, 2008.

${ }^{56}$ BROOK, P.O Cerejal, Uma Imensa Vitalidade. In. Théâtre en Europe. No 2 (Avr. 1984). p. 50-53. Trad. Regina Guimarães. Apud. O Tio Vânia: [Programa]. Porto: Teatro Nacional São João, 2005. (Cadernos Tchékhov; vol. 1).

${ }^{57}$ É interessante notar como Tchékhov retoma muitos estereótipos já conhecidos na cultura russa para situar seu tom cômico.

${ }^{58}$ LUKÁCS, G. 1967.
} 
comedies. $^{59}$

Por outro lado, é necessário matizar a noção de tridimensionalidade proposta por Gottlieb e mesmo o caráter "humano" de suas personagens. As afirmações de Bitsilli a respeito dos protagonistas tchekhovianos parecem bastante elucidativas a esse respeito, pois consideram na própria composição das personagens a predisposição à inação:

A Chekhov character is least of all a "monad", in the sense of embodying some kind of idea. $\mathrm{He}$ is, rather, if one may put it this way, a geometric point of intersection of all possible sensations, an object of external influence rather than a subject, and his residual humanity consists in responding to the outside pressures with his mind and heart ${ }^{60}$.

Apesar de Bitsilli defender que as personagens não são a materialização de uma ideia, sua fala não se contrapõe àquela acima de Peter Brook, sobre a multiplicidade de pontos de vista. O teórico russo, aqui, se refere à utilização da personagem como espécie de argumento dentro da obra de arte, como se poderia encontrar em Tolstói, autor com o qual contrasta Tchékhov. Diferentemente, as personagens tchekhovianas são definidas por seus ambientes sociais e os representam, ou seja, explicitam características de seu próprio meio e, assim, os diferentes "pontos de vista" mencionados. Nesse sentido, corrobora-se a ideia de que não se dividem em bons e maus, já que não são sequer sujeitos, e também a ideia de que sua inação é um fator estrutural de sua composição. Ao mesmo tempo, cabe entender que a afirmação de Bitsilli não exclui as subjetividades e as psicologias das

\footnotetext{
${ }^{59}$ GOTTLiEB, V. Chekhov's Comedy. In. Org. GOTTLIEB, Vera, e Paul Allain. The Cambridge Companion to Chekhov. Cambridge: Cambridge University Press, 2000. P. 230.

Tradução:

Como com a maioria de suas personagens, sua qualidade tridimensional resulta numa perspectiva 'realista', com aspectos frágeis e decentes em cada personagem, e nenhum sentido de 'preto no branco' que informava os personagens e enredos estereotípicos de muitas comédias populares contemporâneas.
}

${ }^{60}$ BITSILLI, P. From Chekhonte to Chekhov.In.: ERLICH, Victor (Org.). Twentieth -Century Russian Literary Criticism. New Haven: Yale University Press, 1975. p. 217

Tradução:

Um personagem tchekhoviano é menos ainda uma 'mônada', no sentido no qual encarnaria algum tipo de ideia. Ele é, sim, se poderia ser colocado desta forma, um ponto geométrico de intersecção de todos os tipos possíveis de sensações, um objeto de influência externa no lugar de um sujeito, e sua humanidade residual consiste em responder às pressões externas com sua mente e seu coração. 
personagens, contidas em suas reações com o coração e a mente.

Assim, não obstante Lopákhin compre o amado jardim de Raniévskaia e comece a derrubá-lo sem ao menos esperá-la partir, ele não se apresenta como vilão. E Iacha, por mais oportunista que seja, ligando-se à família como forma de escapar daquilo que julga a mediocridade do campo, tampouco pode ser de todo mal visto, embora Gottlieb acredite que em seu retrato transpareça certa desaprovação do autor. Todos agem, porque a forma de composição dramática permite tal aprofundamento, conforme justificativas subjetivas, sociais e históricas, de maneira que não podem ser culpados de fato pela desgraça de ninguém, nem mesmo de si. Ao mesmo tempo, na ausência de vilões, tampouco existem vítimas. Tchékhov não retrata a nobreza decadente como vítima da burguesia em ascensão nem como vítima do processo histórico maior que ali se instaurara. O que se passa é condicionado por variáveis impessoais, que atuam para o bem ou para o mal sem levar em conta os efeitos individuais que possam ter. A história como processo é então referenciada de maneira muito mais fiel por resistir a qualquer tentativa de romantização. A culpa, por assim dizer, permanece totalmente alheia aos seus textos. Mesmo a incapacidade de tomar ação, de lutar por aquilo que quer - como fora esperado dos heróis tradicionais - não é retratada como falha de caráter, pois também encontra suas justificativas dentro da peça e dentro das próprias personagens, "sob um misterioso fluxo subjetivante e um insondável jogo psicológico que ocorre no reverso do texto, enquanto o verso se apresenta estático",61.

Retomando o exemplo da inação de Raniévskaia perante a perda do jardim, percebemos que já na sua própria composição como personagem estava excluída a possibilidade de dividir as terras para construir casas de veraneio.

LIUBA: Cabanas, veranistas - perdão, mas é tão vulgar.

GAIÉV: Concordo plenamente.

LOPÁKHIN: Eu vou chorar. Eu vou gritar. Eu acho que vou ter uma coisa. Não aguento mais!

Vão me levar à loucura! (Para Gaiév.) Sua velha!

GAIÉV: Que é que ele disse?

${ }^{61}$ CAVALIERE, Arlete. Teatro Russo - Percurso para um estudo da paródia e do grotesco. São Paulo: Humanitas e Fapesp, 2009. P. 208. 
LOPÁKHIN: Velha! O senhor é uma mulher velha! (Levanta-se para ir embora.) ${ }^{62}$

Ela é representante paradigmática de um estrato social para o qual a preocupação com o dinheiro é vulgar, e Tchékhov a faz agir em absoluta coerência com isso, pelo desapego que apresenta inúmeras vezes em relação à sua própria falência. Não obstante o fato de não possuir mais dinheiro, o entrega a qualquer um que a peça.

LIUBOV ANDREIEVNA (Olhando dentro a bolsa): Ontem a minha bolsa ainda estava cheia de dinheiro e hoje de novo se esvaziou... A pobre Vária economiza, só nos serve sopa de leite, a criadagem come dia após dia ervilha seca... E eu esbanjo o dinheiro como uma tonta.(Deixa cair a bolsa, as moedas de ouro rolando pelo chão.) Agora esse restinho rola pelo chão. ${ }^{63}$

É importante notar que, embora muitos críticos tomem O Jardim das Cerejeiras como uma tragédia, a peça é uma comédia permeada por traços farsescos. Além dos personagens representarem tipos conhecidos da cultura russa, Gottlieb afirma que há comicidade na própria situação dramática, "the 'comedy' lies in the disparity between aspiration and reality, or between desire and fulfilment. ${ }^{64,}$, ou seja, na disparidade contida na situação inicial a partir da qual o drama se desdobra. Peter Brook acrescenta à análise do aspecto cômico de Tchékhov o comentário de que este, ao invés de distanciar a obra do realismo, lhe garante maior objetividade, retirando do drama os exageros patéticos que, por exemplo, o formato trágico poderia trazer.

A comicidade que pode ser encontrada na formulação das personagens se manifesta na insistência sobre os costumes particulares das diferentes classes representadas, aludindo de maneira clara a figuras bem-conhecidas da cultura russa, como, por exemplo, Trofímov, o eterno estudante, ou mesmo Gáiev, cujos pomposos discursos e falas são sempre interrompidos por ordens de silêncio, um

\footnotetext{
${ }^{62}$ TCHÉKHOV, A.P. 2014. Idem. p.40.

${ }^{63}$ TCHÉKHOV, A.P. 2013. p.89.

${ }^{64}$ GOTLIEB, V. In. Org. GOTTLIEB, Vera, e ALLAIN, Paul . 2000. p. 231.
}

Tradução:

A comédia reside na disparidade entre a aspiração e a realidade, ou entre o desejo e sua satisfação. Bitsilli 
típico representante do arquétipo do homem supérfluo.

GAIÉV: (Gesto de mão): Sou incorrigível - isso eu não discuto. (Irritado, para Iacha que procura uma moeda entre suas pernas.) O que é que você está fazendo aí, rastejando feito..?

IACHA: (Ri.) Não posso conter o riso quando ouço o senhor falar.

GAIÉV: Liuba, é ele ou eu. ${ }^{65}$

GAIEV: Amigos, caros, bons amigos! No momento de abandonarmos esta casa para sempre, como deixar de pronunciar algumas palavras de despedida? Perdoem-me, mas devo expressar os sentimentos que hoje inundam todo o meu ser....

ÁNIA (Suplicando): Tio, por favor!

VÁRIA: Titio, pare com isso!

GAIEV (Abatido): Está bem... uma bola direto na caçapa do fundo... já me calei... ${ }^{66}$

Mesmo na melancolia de Vária há certo exagero, especialmente no que diz respeito à sua vontade idealizada de tornar-se peregrina.

VÁRIA (da porta.): Eu nesse corre-corre pela casa o dia todo... com a cabeça longe... Vivo especulando como poderia arrumar-lhe um marido bom e rico. Então eu me sentiria finalmente tranquila, poderia até tornar-me freira ou ir em peregrinação a Kiev ou a Moscou.. que beleza não seria... andar... errar pelos lugares sagrados....

ÁNIA: Os pássaros já estão cantando lá fora, no jardim! Que horas são? ${ }^{67}$

${ }^{65}$ TCHÉKHOV, A.P. 2014. p. 39.

${ }^{66}$ TCHÉKHOV, A.P. 2013.p.118

${ }^{67}$ Ibidem. p.74. 
Além dos contornos hiperbólicos que as personagens demonstram, há inúmeras cenas dedicadas ao efeito cômico, como a surdez de Firs, a verborragia grandiosa de Gáiev ou a falta de contexto e profunda ironia dos discursos de Trofímov:

GAIÉV: Você sabe quantos anos tem essa estante, Liuba? Só na semana passada quando eu estava mexendo na gaveta de baixo, descobri a data gravada a fogo: 1803 . Cem anos de idade; temos que comemorar este centenário. É um objeto inanimado mas tem vida: guarda livros.

PICHTCHIK (Espantado): Cem anos - quem diria?!

GAIÉV: É. Uma coisa admirável. (Abraça e acaricia a estante). Querida e honrada estante! Glória a ti que por mais de cem anos tens servido aos ideais do bem e da justiça. Teu silencioso apelo ao trabalho profícuo nunca arrefeceu numa centena de anos, mantendo (Lágrimas.), em várias gerações desta família, a esperança de um futuro melhor, a fé no dia de amanhã, e inculcou em nó o sentimento da virtude e da consciência social. (Uma pausa.)

LOPÁKHINE: Bom... (Olha o relógio. $)^{68}$

TROFÍMOV: (Horror): O que é que ela está dizendo?

LIUBA: "Eu estou acima do amor!" Você está acima de coisa nenhuma. Como diz o Firs, você é um bom vale-nada. Você não está acima do amor, Pétia ${ }^{69}$. Você não o alcança.Com 27 anos e não tem uma amante!

TROFÍMOV: (Horror) Que horror! O que é que ela está dizendo?! (Vai saindo para o salão rapidamente, as mãos na cabeça.) Que horror! Eu não aguento isso! Vou embora! (Sai; mas volta logo.) Está tudo acabado entre nós! (Sai, para o salão).

LIUBA (Grita por ele.): Pétia. Espera um pouco, rapaz! Não seja ridículo, garoto. Eu estava brincando! Pétia! (Ouve-se o som de alguém correndo por uma escada e logo caindo com um estrondo. Grito de Ânia e Vária e, logo depois, risos.) Que foi que aconteceu?

ÂNIA: (Entra correndo, rindo): Pétia rolou escada abaixo! (Sai correndo.).

LIUBA: Ridículo. Sempre querendo roubar o espetáculo! $!^{70}$

${ }^{68}$ TCHÉKHOV, A.P. 2014. p.26.

${ }^{69}$ Pétia é o apelido dado a Piotr Trofímov.

${ }^{70}$ TCHÉKHOV, A.P. 2014.p.59. 
O próprio efeito do riso, aqui, serve para desarmar a dualidade entre positivos e negativos, pois, em sua comicidade, reside também um pouco daquilo que a justifica. Tchékhov trata suas personagens com singular carinho e humanidade, mesmo que permita rirem deles vez por outra.

De certo, a ausência de vilões e heróis torna o humanismo de seu olhar ainda mais claro. Ausente quaisquer julgamentos, suas personagens, mais do que dignas de pena, tornam-se dignas de compreensão. "Forgiveness through understanding",71, pede uma das personagens de Tennessee Williams, e é exatamente isso que Tchékhov oferece. Ao trabalhar dramaturgicamente uma situação em sua inteira complexidade, o autor nos permite olhar para todos os elementos em seus contextos, oferecendo-nos a singular visão do humano em interação com a vida e com os outros, sem a distorção imposta pelas inúmeras regras do drama rígido, garantindo-lhe referências à universalidade.

Através da escolha do recorte de suas peças, Tchékhov rompe com os pilares fundamentais de sustentação do drama rígido, de forma a ter de buscar soluções dramatúrgicas para as novas possibilidades que quer abarcar. Na obra de Tennessee Williams, encontram-se muitos desses mesmos traços, que resultam do mesmo tipo de recorte e, portanto, de olhar sobre a realidade a ser representada. A análise se prende aqui a duas de suas peças em um ato, formato este que já implica em algumas soluções formais que podem distanciar sua obra daquela do dramaturgo russo. No entanto, não obstante as adaptações feitas por requisito da composição de textos cênicos mais curtos, as características fundamentais da escrita tchekhoviana aqui permaneçam e, talvez, com ainda mais força do que em suas peças longas.

Toma-se como objeto, então, duas peças do início da longa carreira dramatúrgica de Tennessee Williams, Lady of Larkspur Lotion e The Strangest kind of Romance. Ambas foram publicadas na compilação “27 Wagons Full of Cotton "72”, cuja primeira versão data de 1946 e, a segunda, de 1953, acrescentada de algumas outras peças. Na primeira coletânea, nota-se certa coerência temática entre as peças, que tratam, de maneira geral, do embate entre culturas e épocas contrastantes, tema que se repete, na verdade, por quase toda a obra williamsiana. Do todo, a opção em trabalhar com duas peças específicas se justifica em razão dos objetivos propostos.

\footnotetext{
${ }^{71}$ WILLIAMS, T. 2000.
}

Tradução:

${ }^{72}$ WILLIAMS, Tennessee. 27 Wagons Full of Cotton - and other one-act plays. London: John Lehmann, 1949. 
Lady of Larkspur Lotion é uma peça em que em uma única cena o autor apresenta um pequeno recorte da vida dentro de uma pensão do French Quarter de Nova Orleans. O espaço extremamente limitado conduz a poucos personagens: um Escritor, a Sra. Hardwicke-Moore e a Sra. Wire. A fábula pode ser resumida da seguinte forma: na pensão, a Sra. Wire vai aos aposentos da Sra. HardwickeMoore para cobrar-lhe o aluguel da semana; esta, no entanto, não tem meios de pagá-lo e, tentando mudar de assunto, reclama da quantidade de baratas que há na pensão. Irritada com as desculpas que recebe da Sra. Hardwicke-Moore, que tenta lhe explicar que o dinheiro lhe faltara por causa do atraso nos rendimentos de suas fazendas de borracha no Brasil, a Sra. Wire passa a humilhar sua inquilina, desfazendo a imagem que esta impunha como uma senhora digna das classes abastadas, insinuando que, além de não ter dinheiro, se prostituía. O Escritor, então, entra em cena para defender a falsa aristocrata, questionando a aparente crueldade da senhoria, que resolve deixá-los por hora. A cena termina enquanto os dois, Sra. Hardwicke-Moore e o Escritor conversam.

A ação de The Strangest Kind of Romance se estende por um período muito mais amplo de tempo (do fim do outono à primavera), sendo dividido em quatro cenas, e possui também mais personagens: o Homenzinho, a senhoria, Bella, o Velho, o Boxeador e Nitchevo ${ }^{73}$, a gata. A localização dessa peça é menos detalhada, diz-se que ocorre em uma pequena cidade industrial do centro-oeste americano. Novamente, há uma pensão, na qual todos os personagens vivem sob o mando da senhoria, uma imigrante de família mambembe.

Na primeira cena, o Homenzinho está sendo apresentado pela senhoria aos cômodos disponíveis da pensão; naquele escolhido, nota diversas assinaturas nas paredes e, dentre elas, o desenho de um homem grande e um gato. A senhoria lhe explica que aquelas eram dos diversos ocupantes do quarto, e o desenho havia sido feito por um russo, homem grande e forte, que havia ali se hospedado e adotado uma gata de rua, à qual chamara de Nitchevo. Rapidamente, ela conta sua história, dizendo que o havia indicado para trabalhar em uma das fábricas ali perto e que, com o tempo, o russo fora se enfraquecendo, até finalmente falecer sozinho. O Homenzinho simpatiza-se com a história e resolve ficar, contanto que pudesse manter também a gata ao seu lado. Estando de acordo, a senhoria lhe entrega o quarto e também oferece indicá-lo a uma posição na fábrica. Já na segunda cena, sabe-se que o trabalho na fábrica não vai bem para o Homenzinho, que parece nervoso e sensível demais para ele. A senhoria lhe pergunta o que havia de errado, pois recebera reclamações de seu patrão; o

\footnotetext{
${ }^{73}$ Nitchevo, em russo, significa "nada". O nome do gato parece fazer referência à definição dada pelo Homenzinho a si mesmo, quando afirma não ser sequer uma pessoa, ser um nada.
} 
Homenzinho não sabe dizer ao certo. Na terceira cena, ao voltar do trabalho à noite, o Homenzinho se encontra com o Velho, e eles conversam sobre a solidão, a inconstância dos gatos, a amizade verdadeira e o trabalho na fábrica, assunto esse que parece suscitar muita revolta no Velho, que cria um gigantesco tumulto ao começar a gritar para fora da janela (da qual se avistava a fábrica) um discurso de cunho claramente de esquerda. A senhoria se irrita e chama a polícia para levá-lo. Na última cena, que se passa já algum tempo depois, o Homenzinho retorna à pensão e, em seu quarto, não encontra sua velha companheira, a gata, e, sim, um jovem boxeador para quem o quarto havia sido alugado. Confuso, começa a bradar por sua gata, ao que o Boxeador responde que a senhoria a havia chutado da pensão. A confusão também faz com que a senhoria venha ver o que se passa e, encontrando o antigo inquilino, lhe explica que perante o seu desaparecimento, havia alugado o quarto para outro e afastado a gata de lá. A única preocupação do Homenzinho, no entanto, é com a gata, e ele sai à sua procura pelas ruas, enquanto o Boxeador e a senhoria o observam pela janela. A peça termina com o Velho encontrando a gata para o Homenzinho e os três indo embora - o que é somente contado pelos dois personagens que haviam ficado na pensão.

As fábulas de ambas as peças, mesmo que sumariamente contadas, evidenciam alguns aspectos importantes de sua composição. Seus recortes são bastante específicos, de forma a criar situações dramáticas fortes o suficiente para carregarem o drama - nas quais Tennessee dizia residir poesia, tanto quanto na linguagem. É das situações dramáticas que se extrai o movimento da peça, de maneira análoga àquela encontrada em Tchékhov e exposta acima. O formato da peça em um ato já, por si só, contempla tal princípio, como expõe Szondi:

A peça em um ato moderna não é um drama em miniatura, mas uma parte do drama que se alçou à totalidade. Seu modelo é a cena dramática. Isso significa que a peça em um ato se, dúvida compartilha com o drama o ponto de partida - a situação -, mas não a ação na qual as decisões das dramatis personae continuamente modificam a situação inicial, impelindo-a para o termo final do desenlace. Como a peça em um ato não mais deriva sua ação daquilo que acontece entre os homens, é preciso que esta já esteja ancorada na situação. E isso não simplesmente como algo virtual, que a cada nova réplica dramática então se efetiva (a tensão no drama é criada dessa forma), mas como algo dado inteiramente pela situação. (...) A catástrofe já é um dado do futuro: não se assiste mais à luta trágica do homem com o destino, cuja objetividade o primeiro poderia contrapor sua liberdade subjetiva (no sentido de Schelling). O que separa o homem da ruína é o tempo vazio que não pode mais ser preenchido por qualquer ação, e é nesse espaço puro, tensionado em direção à catástrofe, que ele foi condenado a viver. Assim, a peça em um ato se confirma também nesse ponto formal como o 
drama do homem que não é livre. ${ }^{74}$

Através da citação, verifica-se então que o recorte temático já se encontra pressuposto na própria escolha da forma. Como as fábulas já contadas evidenciam, seus temas têm objetivos e limites claramente demarcados, sem a pretensão de que nada extrapole as possibilidades de expressão do pequeno espaço pelo qual o dramaturgo optou.

Embora aquilo que Szondi afirma não se constitua em uma fórmula, pode-se verificar sua validade em relação às peças de Tennessee Williams aqui mencionadas: ambas têm como base uma situação dramática cujo vetor aponta à ruína do homem. Em Lady of Larkspur Lotion, a situação limite que ali se configura é a de uma mulher cujos recursos estão se esvaindo. Não se trata só de recursos financeiros, ela está falida e a senhoria sabe, mas as ferramentas da qual se utiliza para sustentar sua existência em condições tão adversas, ou seja, aquele mundo ficcional sobre o qual se apoia, também vê-se ameaçado pela descrença absoluta com a qual a Sra. Wire com ela lida.

MRS. WIRE: No, I mean I insist upon having the rent you owe me.

MRS. HARDWICKE-MOORE: Right at that moment that is out of the question.

MRS.WIRE: Out of the question, is it?

MRS. HARDWICKE-MOORE: Yes, and I'll tell you why! The quarterly payments I receive from the man who is taking care of the rubber plantation have not been forwarded yet. I've been expecting them to come for several weeks now but in the letter that I received this morning it seems there has been some little misunderstanding about last year's taxes and -

MRS. WIRE: Oh, now stop it, I've heard enough of that goddamn rubber plantation! The Brazilian rubber plantation! You think I've been in this business seventeen years without learning nothing about your kind of women?

MRS. HARDWICKE-MOORE (Stiffly): What is the implication in that remark?

MRS. WIRE: I suppose the men you have in here nights come in to discuss the Brazilian rubber plantation?

$(\ldots)$

MRS. WIRE (turning on MRS. HARDWICKE-MOORE): You with your Brazilian rubber plantation. That coat-of-arms on the wall that you got from the junk-shop - the woman who

${ }^{74}$ SZONDI, P. 2011. p. 93 
sold it told me! One of the Hapsburgs! Yes! A titled lady! The Lady of Larkspur Lotion ${ }^{75}$ ! There's your title! (MRS. HARDWICKE-MOORE cries-out wildly and flings herself face down on the sagging bed. $)^{76}$

O conflito ${ }^{77}$ da peça reside no combate entre personagens cujas realidades e, por conseguinte, subjetividades, são diametralmente inversas, ou seja, entre suas subjetividades e a situação dramática que obriga a convivência intensa e próxima entre elas. Há, por um lado, a Sra. Wire, que figura como paradigma da mulher que venceu os obstáculos e alcançou um relativo nível de sucesso, pois, embora seja dona de uma pensãozinha num bairro pobre de Nova Orleans, ainda assim tem estabilidade e meios moralmente honestos de se manter (segundo os critérios determinados pela própria peça). Sua origem nas classes baixas de Nova Orleans pode ser inferida pelas marcas de linguagem que aparecem em suas falas ("subjeck", “colleck”, em lugar de subject e collect); sua visão é dura e objetiva, e é sob esse ponto de vista que julga o mundo. Por outro lado, há a Sra. Hardwick-Moore, que se configura como personagem fraca, abatida pela vida, a quem se apresenta a necessidade tão gritante de evasão que passa a habitar um mundo fictício, no qual não é preciso se prostituir para pagar o aluguel semanal na pensãozinha, pois os dividendos de uma fantástica plantação de borracha no Brasil facilmente quitariam suas dívidas. É a personagem do Escritor que levará essa incompatibilidade entre os mundos representados ao centro da peça e servirá como mediador entre um mundo e outro, pois entre eles não há meios de comunicação.

Como em Tchékhov, os diálogos parecem não se comunicar porque a realidade sobre as quais

${ }^{75}$ Larkspur Lotion era uma loção herbal utilizada para matar piolhos, chatos e outros parasitas.

${ }^{76}$ WILLIAMS, T. 1949. p. 69-70

Tradução:

SRTA. WIRE: Não, quer dizer que eu insisto em receber o aluguel que me deve.

SRTA. HARDWICKE-MOORE: Neste momento, isso está fora de questão.

SRTA. WIRE: Fora de questão, é?

SRTA. HARDWICKE-MOORE: Sim e eu te direi porque! Os rendimentos trimestrais que recebo do homem que cuida das plantações de borracha ainda não foram encaminhados. Já os espero há algumas semanas, mas pela carta que recebi hoje de manhã, parece que houve um pequeno mal entendido em relação aos impostos do ano passado e -

SRTA. WIRE: Ah, agora chega, já ouvi o suficiente dessa maldita plantação de borracha! A plantação brasileira de borracha! Você acha que eu mantive este negócio por dezessete anos sem aprender nada sobre o seu tipo de mulher?

SRTA. HARDWICKE-MOORE (rigidamente): Qual a implicação desse comentário?

SRTA. WIRE: Eu suponho que os homens que recebe aqui de noite vêm para discutir a plantação de borracha?

(...)

SRTA. WIRE: Você e a sua plantação de borracha. Esse brasão na parede que comprou na casa de penhores - a mulher que te vendeu isso me contou! Uma das Hapsburgos! Sim! Uma dama de títulos! Uma dama da loção de piolhos! Aí está seu título! (SRTA. HARDWICKE-MOORE lança um grito selvagem e se lança de barriga para baixo sobre a cama flácida.)

${ }^{77}$ Adotando a teoria de Lukács, na qual o conflito no drama moderno existe de forma diferente àquela do drama clássico, se estabelecendo entre as subjetividades das personagens e suas realidades externas. 
se pautam as diferentes enunciações são profundamente distintas. Sra. Wire é uma personagem caracterizada pelo pragmatismo, ela não se importa com aquilo que seus inquilinos fazem, contanto que paguem seus aluguéis nos devidos prazos. Ela representa um mundo de negócios, onde a palavra final é o dinheiro e para o qual pouco importam as fantasias e os desejos, o válido é aquilo que é fruto do trabalho honesto.

MRS. WIRE: I never spy and I never listen at doors! The first thing a landlady in the French Quarter ${ }^{78}$ learns is not to see and not to hear but only collect your money! As long as that comes in - okay, I'm blind, I'm deaf, I'm dumb! But soon as it stops, I recover my hearing and also my sight and also the use of my voice ${ }^{79}$.

Para ela, aquilo que a Sra. Hardwicke-Moore diz e a imagem que tenta projetar não são vistos como um meio de sobrevivência para alguém cuja realidade é terrível, mas como mentiras e trapaças.

MRS. WIRE: (...) don't try to pull that beautiful wool over my eyes. I'm glad you come in now. Now I repeat for your benefit what I just said to this woman. I'm done with dead beats! Now is that plain to yuh? Completely fed-up with all you Quarter-rats, half breeds, drunkards, degenerates, who try to get by on promises, lies, delusions $!^{10}$

A agressividade com a qual se volta a ela torna-se assim justificada, pois na sua concepção de mundo não cabe esse tipo de análise, em que se considera o ser humano preso à sua situação. O que ela não

${ }^{78}$ French Quarter é o bairro central de Nova Orleans, Louisiana, a parte mais famosa e antiga da cidade, caracterizada por sua arquitetura de inspiração francesa.

${ }^{79}$ WILLIAMS, T. 1949, p.70.

Tradução:

Sra. Wire: eu nunca espiono e eu nunca ouço às portas! A primeira coisa que uma senhoria no French Quarter aprende é não enxergar e não ouvir e só coletar o seu dinheiro! Contanto que o dinheiro entre - ok, eu sou cega, surda e burra! Mas assim que ele para de entrar, eu recobro minha audição e também a minha vista e também o uso da minha voz.

${ }^{80}$ WILLIAMS, T. Op. cit., p.70.

Tradução:

Sra. Wire: (...) não tente me enganar com essas belas mentiras. Eu estou feliz que tenha entrado agora. Agora posso repetir para seu proveito aquilo que acabei de dizer para esta mulher. Eu estou cheia de perdedores! Isso está claro para vocês? Completamente cheia de todos vocês ratos de rua, vira-latas, bebuns, degenerados, que tentam sobreviver de promessas, mentiras e ilusões. 
enxerga é que nasce da necessidade a criação desses mundos ficcionais, criados para fantasiar a dura realidade que as personagens habitam. Essa incompreensão é bastante similar àquela presente na peça de Tchékhov: nasce de um julgamento que a personagem elabora a partir de sua própria realidade e, concepção de mundo, sobre um outro a quem aqueles parâmetros não se aplicam, pois representa e, de certa forma, habita um conjunto inteiramente diferente de referências. Aquilo que é visto com horror por uns - como admitir sua condição de pobreza e decadência, realizando que é necessário se prostituir ou alugar seus terrenos (como Raniévskaia de Tchékhov) -, para outros não passa de fatos necessários e que não suscitam qualquer tipo de comoção sentimental.

Tchékhov e Tennessee exploram com maestria os resultados conflitantes que nascem de uma realidade total formada por uma infinidade de realidades pessoais e subjetividades, entre as quais não há qualquer possibilidade de entendimento.

Nas peças em questão, há representantes do mundo das objetividades, cujas opiniões parecem mais pautadas no mundo empírico da peça e que encontram respaldo nos valores dominantes de suas épocas, como é Lopákhin, Iacha, Sra. Wire e Bella, a senhoria de The Strangest Kind of Romance. Disputando espaço, aparecem em cena, ao mesmo tempo, Liubov, Trofímov, o Homenzinho, o Velho, a Sra. Hardwicke-Moore e o Escritor. Esses, desde o início, ocupam posição de desvantagem perante os primeiros por não representarem o senso comum. Se, em Tchékhov, o mundo inicialmente glorioso ao qual os "marginalizados" pertencem agora se encontra em plena decadência e processo de extinção, em Tennessee Williams ele tampouco tem existência concreta, pois, de certa forma, é um mundo que existe como mitologia idealizada de um passado que não necessariamente foi seu, nem necessariamente existiu. Eles aludem a valores que se imaginava estarem atrelados à antiga ordem de honra, cultivo e gentileza idealizadamente projetada sobre as camadas ricas de um sul devastado pela Guerra Civil, cuja elaboração simbólica se desdobrava como luta contra o capitalismo industrial.

A oposição entre sistemas propriamente econômicos, que subjaz nas demais peças mencionadas, ganha maior centralidade na peça The Strangest Kind of Romance. Nela se articulam discursos que se voltam de maneira mais clara ao tema. Na figura do Velho está presente uma posição crítica bastante estruturada, como se vê no excerto a seguir:

OLD MAN (a fanatical light coming into his clouded eyes): Uh-huh! I know those fellows that operate the plant, I know the bosses. They know I know them, too. They know I know their tricks. That's why they hate me. Look. Suppose I demand for what they make me slack off. There's two things they could do. They could cut down the price and so put the product within 
the purchasing power of more consumers. Listen! I've read books on the subject! But, no! There's another thing they could do. They could cut down on the number of things they make - create a scarcity! See? And boost the price still higher! And so maintain the rich man's margin of profit! Which do you think they'd do? Why, God Almighty - Nitchevo knows the answer! They'd do what they've always done. (He chuckles and rises and begins to sing in a hoarse cracked voice.)

Hold up, hold up the Profit,

Ye Minions of the Boss!

Lift high the Royal Profit,

It must not suffer loss!

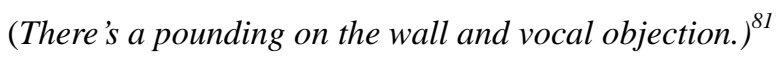

A repercussão que o inflamado discurso gera dentro da peça, não obstante sua articulação sólida e objetiva, é bastante vazia no sentido de uma conscientização de classes. A reação que obtém dos diversos outros moradores, que esboçam profundo incômodo perante a gritaria, é de que não se passava de gritos ilusórios de um velho bêbado, como a própria Senhoria diz: “Ahh, you drunken fool, my patience is gone. Officer, take him away. Lock him up until he comes to his senses ${ }^{82, "}$ Novamente nota-se a ineficiência dos diálogos: as falas são direcionadas com ímpeto a um exterior no qual só encontram vazio, dado que não há chance alguma de compreensão. Sob o rótulo de bêbado tolo, as palavras do Velho se mantêm ocas no ouvido daqueles que o julgam, impossibilitando seu alcance. Ao mesmo tempo, para o Homenzinho, a cena toda toma um rumo diferente. Mesmo que não

${ }^{81}$ WILLIAMS, Tennessee. 27 Wagons Full of Cotton - and other one-act plays. London: John Lehmann, 1949. P. 140-141.

Tradução:

VELHO (uma luz fanática aparece em seus olhos turvos): Uh-huh! Eu conheço esses caras que operam a planta, eu conheço os patrões. Eles sabem que eu os conheço. Eles sabem que eu conheço seus truques. É por isso que eles me odeiam. Veja. Suponha que eu demande aquilo que eles me fazem perder. Há duas coisas que poderiam fazer. Eles poderiam abaixar o preço e então colocar seu produto à disposição de um número maior de consumidores. Ouça! Eu li livros sobre o assunto! Mas, não! Tem outra coisa que poderiam fazer. Eles podem abaixar o número de coisas que fazemcriar a escassez! Vê? E aumentar ainda mais os preços! Qual você acha que eles fariam? Oras, por Deus todo poderoso Nitchevo sabe a resposta! Eles fariam o que sempre fizeram! (Ele ri, levanta e começa a cantar com voz arranhada e rouca). Mantenham, mantenham o lucro alto / subordinados do patrão / levantem o nobre lucro / levantem-no sem perdão! (Ouvem-se pancadas na parede e objeções).

${ }^{82}$ WILLIAMS, T. Idem. p.143.

Tradução:

Ah, seu tolo bêbado, minha paciência acabou. Policial, leve ele embora. Tranque ele lá até que volte ao normal. 
reaja, segundo aquilo que a peça mostra, politicamente àquilo que dissera o Velho, o conflito que enxerga entre as diferentes manifestações, como o intento do Velho que brada e o agressivo descaso com o qual a Senhoria lida com seu lamento, de certa forma evidencia uma característica daquela circunstância com a qual não consegue lidar.

LANDLADY (uneasily): Why that look? What's the meaning of it?

LITTLE MAN: I'm not looking at you. I'm looking at the evil in the world. Turn out the light. I've lived too long in a room that was nothing but windows and always at noon and with no curtains to draw. Turn out the light. (She reaches slowly above her and switches it off. He suddenly goes to her and plunges his head in her chest.) O beautiful, cruel Zigeuner! Sing to me, sing to me! Comfort me in the dark! (At first she stands stiff and hostile. Then she relents and embraces his crouching body and begins to sing softly.)

CURTAIN $^{83}$

A ruína do Homenzinho perante uma realidade que a ele se mostra como o Mal, diferente daquela do Velho, recebe certo acolhimento pelo outro lado, na figura de Bella. A sua fala e o seu desespero não apontam dedos a ninguém e tornam-se gritos genéricos contra as deficiências de um mundo que parece insuficiente a todos. De certa forma, o movimento de entrega do Homenzinho àquela circunstância que o consome por inteiro é tão intenso que consegue de fato alcançar os ouvidos surdos da Senhoria, que, embora resista no início, cede e tenta o confortar. É interessante notar aqui que a comunicação só se estabelece porque as diversas ilusões que permeiam os mundos pessoais das personagens são dissipadas, porque há algo de traiçoeiro na linguagem, como se esta tivesse uma predisposição à ilusão, funcionando como barreira. No momento da quebra, a fala do Homenzinho deixa de lado a intenção comunicativa e, adentrando o gênero lírico, se transforma em pura expressão. Como expressão de desamparo e desilusão não há espaço semântico naquelas

\footnotetext{
${ }^{83}$ WILLIAMS, T. 1949.p.144.
}

Tradução:

SENHORIA (preocupada): Por que esse olhar? O que ele significa?

HOMENZINHO: Eu não estou olhando para você. Eu estou olhando para o mal no mundo. Apague a luz. Eu vivi por tempo demais num quarto que era só janelas ao meio dia, sem cortinas para fechar. Apague a luz. (Ela lentamente alcança sobre ela e apaga a luz. Ele de repente corre até ela e enfia sua cabeça no seu peito.) Oh, linda, cruel Zigeuner! Canta para mim, canta para mim! Me conforte na escuridão! (De início, ela se mantém rígida e hostil. Depois ela cede e abraça seu corpo encurvado e começa a cantar lentamente.)

CORTINA. 
palavras para que mundos distintos ou barreiras se ergam, pois o sentido comunicativo foi abandonado, de forma que aqueles sons produzidos pela fala ganhem a forma de símbolos universais.

Algo análogo acontece na última cena de $O$ Jardim das Cerejeiras, quando Liubov e Gáiev finalmente se veem a sós, encontrando um minúsculo espaço para manifestarem toda a angústia e o pesar que o processo pelo qual passaram na peça os havia gerado. Abrem-se por um instante, sem que ninguém os olhe, e enxergam juntos a realidade objetiva que se apresenta, talvez pela primeira vez, na mais translúcida precisão. Gáiev, cujo discurso até então era pomposo e cheio de firulas, se resigna em função fática, expressando sua presença e seu entendimento, enquanto Raniévskaia assinala com sua fala como finalmente se despedia, sem máscaras, de algo cujo fim já se havia anunciado desde muito.

LOPÁKHIN: Até a primavera, então. Até outra vez! (Sai. Liuba e Gaiév ficam sós. Como se esperassem esse momento, atiram-se um nos braços do outro.Choram baixinho, evitando serem ouvidos.)

GAIÉV (Desespero.): Minha irmã! Minha irmã!

LIUBA: O meu jardim! Meu carinhoso, meu lindo jardim! Minha vida, minha juventude, minha felicidade! Adeus! Adeus!

ÂNIA (Voz fora de cena, alegre.): Mamãe!

TROFÍMOV (Voz fora de cena, alegre.): Ehiiiiii!

LIUBA (Como quem responde, mas baixo.): Já vou. Só mais um olhar nas paredes... nas janelas. Mamãe gostava especialmente desta sala.

GAIÉV: É mesmo. (Saem. A cena está vazia. Há o som de portas sendo fechadas. Depois, silêncio. E aí um golpe de machado numa árvore, ecoando um som triste e solitário. Passos.). ${ }^{84}$

Como foi o caso do Homenzinho, à Raniévskaia se apresenta uma verdade da qual até então se desvencilhara, e na sua entrega a essa verdade manifesta encontra acolhimento. Cabe talvez pontuar que esse acolhimento é o do homem perante a humanidade, um acolhimento que extrapola os detalhes que compõem a própria quebra, pois independe das justificativas e dos pontos de vista que caracterizam as personagens.

${ }^{84}$ TCHÉKHOV, A.P. 2014.p.78. 
É essencial perceber o caráter traiçoeiro da linguagem como única solução para as situações que se apresentam nas três peças aqui analisadas. No momento em que se faz necessário criar mundos alternativos sobre os quais se fundamentar, às personagens não se apresenta outro meio que não o da linguagem, como se suas existências se dessem a partir de uma narrativa pessoal. A concretude, no entanto, lhes é dada por meio de gestos, costumes e detalhes, como o brasão familiar que a Sra. Hardwicke-Moore tem pendurado sobre a cama, a maneira inconsequente de Raniévskaia lidar com o dinheiro, mesmo falida, ou a relação de carinho e companheirismo que o Homenzinho desenvolve com sua gata Nitchevo. A existência dual que levam tais personagens - pois elas habitam concretamente um mundo pautando-se sobre regras e valores de outro ${ }^{85}$ - certamente guarda em seu âmago um conflito potencial. Raymond Williams explora esse potencial intrínseco ao conflito em seu texto Tragédia Privada: Strindberg, O’Neill, Tennessee Williams ${ }^{86}$, embora acredite que o crítico exagere a força negativa que existe em tais embates, como se as personagens agissem pela crueldade, retirando força da situação:

Mas há um outro tipo de tragédia, superficialmente muito parecido com esse, que na verdade começa com o homem nu e desamparado. Toda energia primária centra-se nesse ser isolado que deseja, se alimenta e luta a sós. A sociedade é, na melhor das hipóteses, uma instituição arbitrária para impedir que hordas de criaturas destruam umas às outras. E, quando essas pessoas isoladas se encontram nos chamados relacionamentos, as suas trocas são, inevitavelmente, formas de luta. ${ }^{87}$

As peças evidenciam as diversas verdades sobre as quais se erguem em competição esperanças,

${ }^{85}$ Tennessee Williams, em A noite do Iguana, ilustra a existência dual:

SHANNON: (looking out gloomily from the verandah): Yeah, well, you know we - live on two levels, Miss Jelkes, the realistic level and the fantastic level, and which is the real one, really...

HANNAH: I would say both, Mr. Shannon.

SHANNON: But when yoou live on the fantastic level as I have lately but have got to operate on the realistic level, that's when you're spooked, that's the spook.

Tradução:

SHANNON (olhando pesarosamente pela varanda): É, bem, você sabe nós - vivemos em dois níveis, Srta. Jelkes, o nível realista e o nível fantástico, e qual é o verdadeiro, realmente...

HANNAH: Eu diria que ambos são, Sr. Shannon.

SHANNON: Mas quando você vive no nível fantástico, como eu tenho vivido ultimamente, mas tem que operaar no nível realista, é aí que você fica assustado, isso é o susto...

WILLIAMS, T. Plays: 1957-1980. New York: Library of America, 2000. p.380.

${ }^{86}$ WILLIAMS, R. Tragédia Moderna. 2a Edição. São Paulo: Cosa Naify, 2011.

${ }^{87}$ Ibidem. P.143. 
sonhos e expectativas. Como se ganhando a disputa, mesmo aquela mais distante da realidade determinada pela peça, as possibilidades de resultado pudessem ser mudadas. "The problem is that unless they can persuade others to join them in their illusions they are thereby condemning themselves to isolation. ${ }^{\prime \prime 8}$ A citação de Bigsby traz à tona, no entanto, a consequência dual desse processo: ao passo que as personagens encontram refúgio, o fazem somente corroborando seu terrível isolamento. É somente naqueles momentos em que a linguagem - como substrato das ilusões - se perde, que conseguem alcançar uns aos outros.

O fim das personagens, para Szondi, está claro e determinado; não há como fugir daquilo que será certamente o resultado final das situações apresentadas. Porém, na insistência sobre as existências alternativas, é como se as personagens encontrassem refúgio, podendo postergar não o fim em si, mas a sua percepção. Mesmo em Tchékhov, cuja peça não apresenta um só ato, por funcionar por meio de um mecanismo situacional análogo, a sorte das personagens está lançada desde o início da peça, de modo que, também elas, não são dotadas de liberdade. Bastante ilustrativa é a afirmação de Hauser sobre as personagens tchekhovianas, que serve igualmente às de Tennessee, com a ressalva de que não acreditamos se tratar de resignação, mas de uma falta objetiva de possibilidades de ação:

Os personagens não lutam, não se defendem, não são derrotados - simplesmente afundam aos poucos, tragados pela rotina de suas vidas sem acidentes nem esperanças. Suportam o próprio destino com paciência e resignação, um destino que não se consuma em catástrofe, mas na forma de desapontamentos. ${ }^{89}$

$\mathrm{Na}$ ausência de liberdade de todos está parcialmente implícito que não existem vilões. Da mesma forma como se percebe que não é de Lopákhin a culpa pela perda do jardim de cerejeiras, também não é culpa da Sra. Wire ou de Bella a situação das demais personagens. Embora exerçam o papel de catalisadores, pois é por meio delas que a podridão de suas realidades se torna mais aparente, não está contido em suas ações o determinante da própria situação. A falta de culpabilidade

\footnotetext{
${ }^{88}$ BIGSBY, Christopher W. E. Modern American Drama 1945 - 2000. Edição para Kindle. Cambridge: Cambridge University Press, 2000. p. 674.

Tradução:

O problema é que, a não ser que consigam convencer os demais a juntar-se às suas ilusões, eles estão condenando a si mesmos ao isolamento

${ }^{89}$ HAUSER, Arnold. História Social da Arte e da Literatura; Ed. Martins Fontes; São Paulo; $2003 ;$ p.939.
} 
dos diversos sujeitos, cujos destinos são determinados circunstancialmente, parece apontar a um erro fundamental na própria situação. Sem enunciar nada em relação a isso, a forma mesma como se estrutura o drama e nele se dispõem as personagens e suas derrotas, parece pontuar que o conflito não reside então no sujeito, mas na sua relação com a situação dada de início.

De acordo com Lukács ${ }^{90}$, o indivíduo condicionado circunstancialmente gera uma condição de relativismo, na medida em que suas ações sempre podem ser justificadas e, assim, compreendidas. Daí, depreende-se a inevitável ausência de vilões e também o caráter intersubjetivo da ação dramática, em razão dessas ações serem emanadas não da vontade, mas da necessidade circunstancial. A consequência para os conflitos dramáticos é seu quase desaparecimento, posto que se tornam mera questão de ponto de vista.

How different are conflicts where the individual is taken for the mere proxy of something external to him, something objective, conflicts where the pairing of particular opponents is virtually accidental, the result of intersected necessities. ${ }^{91}$

Nas obras de Tennessee Williams também não se encontra o típico maniqueísmo do drama burguês, desarmado por seu caráter circunstancialmente justificado, juntamente com o uso que faz do humor e da ironia, muito similar à maneira de Tchékhov. M.D.S. Ilari ${ }^{92}$ propõe que a comicidade de Tennessee seja lida pelo conceito de J. L. Styan de dark comedy, segundo o qual a peça, como microcosmo, deve conter os mais antagônicos elementos em íntima convivência, como o cômico e o não cômico, de modo que o público não consiga de fato direcionar sua lealdade a nenhum dos personagens e, assim, não se estabeleça a leitura fácil do todo apresentado. Desta forma, nem à pura comédia, com a qual o leitor se distanciaria em demasia das personagens, tornando-se mero

\footnotetext{
${ }^{90}$ LUKÁCS, G. 1965.

${ }^{91}$ LUKÁCS, G. 1965. p.164
}

Tradução:

Quão diferentes são os conflitos nos quais o individual é tomado como mero representante de algo externo a ele, algo objetivo, conflitos nos quais a aproximação de oponentes é virtualmente acidental, o resultado de interseção de necessidades.

92 ILARI, Mayumi Denise Senoi. 27 Wagons Full of Cotton, Baby Doll e Tiger Tail: Recriações da História Social NorteAmericana no Teatro de Tennessee Williams. Campinas, 2000. 
observador sem compaixão, nem à tragédia pura, para o sucesso da qual deveria se estabelecer a empatia absoluta com as personagens, tendem as peças de Williams e Tchékhov.

O elemento do riso também pode ser encontrado nas peças analisadas, por vezes beirando o grotesco, como na incrível afetação da Sra. Hardwicke-Moore ou em seu longo discurso sobre as baratas voadoras e as baratas pedestres.

MRS. HARDWICKE-MOORE (humorously, but rather painfully smiling): Mrs. Wire, I'm sorry to say that I just don't consider cockroaches to be the most desirable kind of room-mates - do you?

MRS. WIRE: Cockroaches, huh?

MRS. HARDWICKE-MOORE: Yes. Precisely. Now I have had very little experience with cockroaches in my life, but the few that I've seen before have been of the pedestrian kind, the kind that walk. ${ }^{93}$

Em The Strangest Kind of Romance, encontra-se o uso do expediente cômico em muitas das falas de Bella, a senhoria, e em suas tentativas de sedução bastante fora de contexto, dadas as qualidades sensíveis do Homenzinho.

LANDLADY: He grunted. (She smiles. The LITTLE MAN pours the rest of the cream in the cat's saucer. He's trembling.) You must try an' get over being so nervous. Maybe what you need is more amusement. (She sits on the edge of the bed, with the balalaika.) Sit back down! There's room for two on this sofa! (She pats the space beside her. He gingerly sits back down at a considerable distance. His hands knot anxiously together. She plays a soft chord on the balalaika and hums with a sidelong glance at the nervous roomer.) Tired? ${ }^{94}$

${ }^{93}$ WILLIAMS, T. 1949. p. 67

Tradução:

SRA. HARDWICKE-MOORE (com humor, mas sorrindo dolorosamente): Sra. Wire, desculpe-me por dizer, mas eu simplesmente não considero baratas o melhor tipo de companheiro de quarto - você considera?

SRA WIRE: Baratas, né?

SRA. HARDWICKE-MOORE: Sim. Exatamente. Agora, eu tive pouquíssima experiência com baratas durante a minha vida, mas as poucas que encontrei foram de um tipo pedestre, um tipo que anda.

${ }^{94}$ WILLIAMS, T. 1949. p.136.

Tradução: 
Convivem nas peças diferentes tipos de comédia: aquela que se dá no exagero das qualidades, que tende por vezes à deformação do grotesco, e aquela que se dá por meio da percepção de atitudes deslocadas, como a atitude de Bella em relação ao Homenzinho, as fantasias da plantação de borracha em relação à verdade, ou mesmo o bradar alucinado do Velho pela janela. Nessa qualidade de gesto deslocado de seu contexto, que gera o riso por meio do estranhamento, podem-se encaixar também, por exemplo, os discursos idealistas e quase revolucionários de Trofimóv perante àquele grupo de aristocratas ao qual aquilo nada significa senão entretenimento.

TROFÍMOV: A humanidade progride, luta pela perfeição. Tudo que agora está fora do nosso alcance um dia será compreensível e trivial; só que é preciso trabalhar, ajudar com toda a nossa força aos que procuram soluções. Aqui na Rússia, por enquanto, são muitos os que falam, poucos os que trabalham. Os intelectuais que conheço não procuram nada, não fazem nada; ficam doentes só com a ideia de qualquer esforço. Intitulam-se humanistas, mas tratam os criados como inferiores e os camponeses como animais. Não sabem coisa alguma, não querem aprender nada, não leem nada a sério e nunca fazem nada. O que falam sobre ciência é ridículo e seu conhecimento de arte é pouco mais que zero. São todos muito sérios, usam caras profundas, discutem assuntos impenetráveis, fazem especulações filosóficas incontestes, e não veem que em volta, todos, - 95 por cento do povo - vivem como selvagens, se insultando e estraçalhando à menor provocação. Comem lixo podre, dormem na imundície e na umidade, trinta ou quarenta no mesmo quarto cheio de percevejos, fezes, fedor e consequente degradação moral. É evidente que todos os nossos belos discursos só têm uma função enganar aos outros e a nós mesmos. Me digam onde é que estão essas creches de que se fala tanto? E as bibliotecas? E a habitação popular? Essas coisas só existem em novelas - na vida real eu nunca vi. Eu só vejo a desordem, a sujeira, a vulgaridade e a preguiça asiática. Eu temo e desprezo as caras austeras e os que falam com solenidade. Todos faríamos muito mais calando a boca. ${ }^{95}$

Vale notar como o cômico, em ambos os escritores, provém da qualidade épica de suas dramaturgias, na qual se faz fundamental o distanciamento e a objetividade. Para se dispor ao riso, lembra Rosenfeld ${ }^{96}$, o público necessariamente deve estar de certa forma insensibilizado com a personagem e a situação, caso contrário, o efeito cômico não se concretiza. Como freio constante à

Senhoria: Ele grunhiu. (Ela sorri. O HOMENZINHO despeja o resto do creme no pote do gato. Ele está tremendo.) Você tem que tentar deixar de ser tão nervoso. Talvez você precise de mais divertimento. (Ela se senta na beirada da cama com a balalaica). Pode se sentar de novo! Tem espaço para dois neste sofá! (Ela bate no espaço ao seu lado. Ele cautelosamente se senta há uma distância considerável. Suas mãos estão entrelaçadas em ansiedade. Ela toca um leve acorde na balalaica e cantarola com uma olhadela de relance para o nervoso inquilino.) Cansado?

${ }^{95}$ TCHÉKHOV, A.P. 2014.p.45-46.

${ }^{96}$ ROSENFELD, A. 2011. p.155-156 
identificação, então, ambos os escritores se utilizam de tal recurso. Em suas escritas existe a preocupação de acessar a expressão de um todo, composto por uma infinidade de partículas menores, que não poderia ser alcançado se a relação tradicional se estabelecesse entre o público e a obra. Encontra-se manifesta tal opinião no desconsolo de Tchékhov em relação à encenação de Stanislávski de $O$ Jardim das Cerejeiras, na qual os traços farsescos foram soterrados por um consciente exagero de melancolia e tragédia. E talvez resida exatamente nisso os mais claros indícios da preocupação de ambos os escritores com a função social de suas peças.

Não há como negar que os quadros pintados pelas obras de Tennessee Williams e Anton Tchékhov estão carregados de crítica social. Por mais que tenham sido taxados como apolíticos por inúmeros críticos, neles existe um olhar atento às realidades que a eles se apresentavam. A inação das personagens muitas vezes foi entendida como espécie de resignação perante seus destinos pessoais e, no entanto, por meio de uma análise mais detida sobre a estrutura dramática que adotaram, depreendese que a possibilidade de ação já independia dos diversos sujeitos. Nas peças, o peso está sobre o contexto no qual se inserem, não nas vontades pessoais das personagens, em seus anseios ou medos. Mais do que uma investida contra a inépcia de seus marginalizados, que são retratados com carinho e humanidade, é possível inferir que se trata de uma crítica a um mundo que força à existência essas situações.

Uma qualidade que pode ter colaborado para que recebessem o rótulo de apolíticos é a ausência de soluções que os textos carregam. Chamados "finais abertos" pela teoria literária, não propõem nem sugerem ao público qualquer resolução para os conflitos apresentados ${ }^{97}$. Guinsburg ressalta esse elemento como resultado do "tratamento impressionista":

extraordinária capacidade de ocultar o sentido, deixando ao leitor e/ou espectador a tarefa de chegar às conclusões (...). Pintura dramática feita como que por manchas de coloração, sem traços de contorno muito nítidos, ela se compõe através dos claros abertos que são verdadeiros

\footnotetext{
${ }^{97}$ É interessante pensar naquilo que Isaiah Berlin acrescenta sobre a ausência de soluções da escrita de Tchékhov, como tal ausência não se trata de falta, mas de uma maneira de atingir a imparcialidade que a representação de uam totalidade implicaria.: "Chekhov once said that a writer's business was not to provide solutions, only to desecribe a situation so, do such justice to all sides of the question, that the reader could no longer evade it."
}

Tradução:

Tchékhov uma vez disse que o trabalho do autor não era o de oferecer soluções, mas de descrever tão bem uma situação, de fazer justiça a todos os lados da questão,de modo que o leitor já não conseguiria fugir dela.

BERLIN, Isaiah. Russian Thinkers. London: Penguin Books, 2008. P. 349. 
campos de sugestão. ${ }^{98}$

As obras de Tennessee Williams, porém, são menos sutis naquilo que diz respeito às conclusões finais, especialmente quando se trata de peças curtas, formato este que, como o conto, ganha o espectador por nocaute, não por pontos ${ }^{99}$. Não obstante seus finais mais abruptos, tampouco é possível se chegar a qualquer concepção programática de um curso de ação que pudesse funcionar como uma barreira para os finais que ali se impõem. Como já foi explicitado por Szondi, o rumo dos dramas em questão já estava dado desde o início, de forma que as peças só poderiam caminhar para seus resultados sem quaisquer possibilidades de intervenção, reiterando a posição gerada pela consciência histórica típica do drama moderno: de que não é de si o destino do homem. É dessa irrevogabilidade que provém a sensação de impotência e, também, a viabilidade do final em pianíssimo, como Tchékhov apreciava.

$\mathrm{Na}$ análise comparativa das dramaturgias de Anton Tchékhov e Tennessee Williams há ainda um outro aspecto essencial a ser mencionado: o realismo. A maneira pela qual estruturam as peças, dando voz a uma multiplicidade de pontos de vista - como já visto com Peter Brook - e carregando de intento aquilo que no drama rígido seria considerado um detalhe irrelevante, auxilia na criação de um

\footnotetext{
${ }^{98}$ GUINSBURG, Jacó. Stanislávski e o Teatro de Arte de Moscou. São Paulo: Editora Perspectiva, 2006. p.90

${ }^{99}$ Referência à analogia criada por Júlio Cortázar para descrever as diferenças entre o formato do romance e o do conto:

"[...] o de recortar um fragmento da realidade, fixando-lhe determinados limites, mas de tal modo que esse recorte atue como uma explosão que abra de par em par uma realidade muito mais ampla, como uma visão dinâmica que transcende espiritualmente o campo abrangido pela câmara. Enquanto no cinema, como no romance, a captação dessa realidade mais ampla e multiforme é alcançada mediante o desenvolvimento de elementos parciais, acumulativos, que não excluem, por certo, uma síntese que dê o 'clímax' da obra, numa fotografia ou num conto de grande qualidade se procede inversamente, isto é, o fotógrafo ou o contista sentem a necessidade de escolher e limitar uma imagem ou um acontecimento que sejam significativos, que só valham por si mesmos, mas também sejam capazes que atuar no espectador ou no leitor como uma espécie de abertura, de fermento que projete a inteligência e a sensibilidade em direção a algo que vai muito além do argumento visual ou literário contido na foto ou no conto. Um escritor argentino, muito amigo do boxe, dizia-me que nesse combate que se trava entre um texto apaixonante e o leitor, o romance ganha sempre por pontos, enquanto que o conto deve ganhar por knock-out."
}

CORTÁZAR, J. Valises de Cronópios. São Paulo: Perspectiva, 2006. p.152. 
panorama realista no qual a totalidade da experiência real ${ }^{100}$ pode ser percebida. Explora-se rapidamente essa característica em Tchékhov, levantando que sua dramaturgia buscava, à maneira dos romances, englobar uma teia complexa de significados e dados interdependentes. Em Tennessee Williams também é possível encontrar tal expediente. Mas é preciso indagar como se caracteriza tal realidade e quais seus elementos constitutivos.

Considerando o desenvolvimento histórico das artes visuais, é possível perceber como o conceito de realismo e suas manifestações mudam conforme as diferentes épocas e culturas. Os quadros realistas de pintores como Vermeer e Caravaggio têm em seu retrato quase fotográfico o realismo, de forma que a ficcionalidade (ou não) de seu tema não importa. Séculos depois, com os impressionistas, é novamente a vontade de retratar fielmente a realidade que guia as explorações técnicas, mas nestas se revelam a ênfase sobre outra faceta da realidade, que se distancia do detalhe fotográfico, por assim dizer, buscando a expressão da impressão total que uma dada cena gera sobre seu espectador. Já os realistas americanos das décadas de 1930-1950, por exemplo, apresentam ainda outro conceito de realidade, no qual não basta somente a incorporação da fidelidade à imagem, mas também as implicações referenciais do tema ali proposto. Assim, pode-se perceber que aquilo que faz da realidade ela mesma, de tempos em tempos, muda, junto com a percepção que os artistas dela fazem e aquilo que julgam serem seus elementos mais importantes.

Para a análise do realismo tchekhoviano e o de Tennessee Williams é, então, indispensável considerar também aquilo que para eles compunha a realidade e como ela poderia se manifestar dramaturgicamente. Como demonstram as peças, a realidade tinha necessariamente uma qualidade de todo, da totalidade da experiência formada a partir da confluência de seus inúmeros elementos e subtramas. Essa qualidade dramatúrgica $\mathrm{Katz}^{101}$ julga pertencente ao realismo moderno, em que

\footnotetext{
${ }^{100}$ Utiliza-se aqui o termo na acepção que recebe tradicionalmente nos meios literários, como o real ao qual o romance, por exemplo, almeja imitar. Nesse sentido, é interessante lembrar, como sugere Ian Watt, que o realismo formal do romance, que se firma como técnica a partir do século XVIII, adota uma visão circunstancial da vida (o naturalismo no teatro). Assim, torna-se ainda mais clara a percepção de que o desenvolvimento do drama, a partir desse momento de crise, se faz, cada vez mais, rumo à épica e seu tipo de relação com a realidade.

101 "Modern realism tolerates only one reality, but jostles multiple narratives within a social frame - a family, a club, a bus, a house, a suburban enclave - all contributing to a composition, na ubernarrative, of psychological and emotional density."

Tradução:

"O realismo moderno tolera só uma realidade, mas lança múltiplas narrativas dentro de um quadro social - uma família, um clube, um ônibus, uma casa, um enclave suburbano - tudo contribuindo para uma composição, uma uber-narrativa, de densidade psicológica e emocional."

KATZ, Leon. Cleaning Augean Stables - Examining Drama's Strategies. Edição para Kindle. Não consta, 2012. Loc. 1849.
} 
múltiplas narrativas são unidas por meio de um recorte social, de forma a dar corpo a uma mesma realidade. Ao mesmo tempo, tal opção dramatúrgica também evidencia um olhar que se distancia dos grandes feitos, como se fossem artificiais, voltando-se para o pequeno e ordinário, onde a verdade estaria contida $^{102}$.

Apesar dos recursos dramatúrgicos utilizados fugirem ao retrato naturalista, está presente em ambos os escritores a constante preocupação em manter-se fiel à realidade múltipla e livre de exageros melodramáticos que enxergam ser a vida. Em uma de suas cartas, escreve Tchékhov:

Why write that a person gets into a submarine and goes to the North Pole to find some kind of reconciliation with humanity, while at the same time the woman he loves hurls herself off the nearest belfry with a theatrical shriek? All this is untrue and does not happen in real life. One must write simply - about how Piotry Semyonovich got married to Marya Ivanovna. That's all $^{103}$.

Através da citação, pode-se inferir que aquilo que o dramaturgo guarda como verdade equivale àquilo que acredita se passar na vida real. Da mesma forma, em Tennessee, também se encontra a mesma identificação entre vida real e verdade, de forma que a busca por uma, no teatro, implicaria na representação correta da outra:

${ }^{102}$ O pesuisador G.S. Morson afirma como qualidade do pensamento russo do século XIX a tendência ao prosaísmo: "Theses Russian heroes [Dostoiévski e Tolstói] learnt two closely related truths. First, the most important events in life are not grand and dramatic but small and ordinary. Second, time is always open and uncertainty pertains to the very nature of things. I like to call the combination of these two truths 'prosaics'."

Tradução:

Estes heróis russos aprenderam duas verdades intrinsecamente relacionadas. Primeiro, que os eventos mais importantes na vida não são grandiosos e dramáticos, mas pequenos e ordinários. Segundo, o tempo está sempre aberto, e a incerteza pertence à natureza mesma das coisas. Eu gosto de chamar a combinação dessas duas verdades de 'prosaismos'.

MORSON, G.S. Tradition and Counter-tradition: the radical intelligentsia and classical Russian literature. In. LEATHERBARROW, L. e OFFORD, D. A History of Russian Thought. Cambridge: Cambridge University Press,2010.LOC 4325

${ }^{103}$ TCHÉKHOV, A. apud GOTTLIEB, V. 2000. p. 228.

Tradução:

"Por que escrever que uma pessoa entra num submarino e vai até o Polo Norte para procurar algum tipo de reconciliação com a humanidade, enquanto, ao mesmo tempo, a mulher que ele ama se lançou do campanário mais próximo com um berro teatral? Tudo isso não é verdade e não acontece na vida real. Deve-se escrever com simplicidade - sobre como Piotr Semiônovitch se casou com Maria Ivánovna. Só isso. 
Everyone should know nowadays the unimportance of the photographic in art: that truth, life or reality is an organic thing which the poetic imagination can represent and suggest, in essence, only through transformation, through changing into other forms than those merely present in appearance. 104

É imprescindível perceber como essa concepção daquilo que constitui a realidade, em sua percepção real, se relaciona com a utilização de recursos outros na escritura teatral daqueles prescritos pelo drama rígido. Não basta representar no palco somente aquilo que aparenta ser a realidade, mas lá expor, mesmo que por vias aparentemente irreais (como seria a utilização de técnicas expressionistas ou exageros grotescos), o mecanismo da realidade; tal escolha, em essência, se contrapõe às imposições do drama rígido. "Com isso, o referente teatral pretende pautar-se pelo real, e não mais obedecer a regras estéticas canônicas e intrínsecas. "105. Lescot prossegue em sua definição do realismo teatral:

Portanto, é aconselhável, contrariando o senso comum, denominar "realista" não o teatro do mimetismo e da reprodução pictórica ou fotográfica do real exterior, mas um teatro que, na linhagem brechtiana, com fins nada menos que científicos, impõe à realidade objetiva inúmeras torções, transposições, transformações, isto é, operações prévias a um realismo da estrutura, um realismo no sentido filosófico.106

Embora a descrição pareça entrar em consonância maior com os valores que Tennessee Williams expressa, não se pode ignorar a dimensão grotesca e paródica tchekhoviana, nem mesmo a estrutura anedótica de suas peças, nas quais são visíveis as transformações operadas em prol, entre outros, do realismo. Ademais, em ambos os escritores existe, igualmente, a presença lírica de subjetividades

${ }^{104}$ WILLIAMS, T. 2000. p.395.

Tradução:

Todo mundo deveria saber, hoje em dia, da insignificância do fotográfico na arte: que a verdade, a vida ou a realidade é algo orgânico que a imaginação poética consegue representar ou sugerir, em essência, somente através da transformação, através de sua transformação em formas diferentes daquelas somente presentes em aparência.

105 (Org.) SARRAZAC, Jean Pierre. Léxico do Drama Moderno e Contemporâneo. São Paulo: Cosac Naify, 2012.p.156.

${ }^{106}$ Ibidem. p. 157 
projetadas sobre os mais diversos elementos: o mais nítido exemplo desse recurso em Tchékhov é o jardim das cerejeiras, cuja dimensão simbólica expõe o fluxo interior de Liúba Raniévskaia. Em Tennessee, talvez o exemplo mais perceptível esteja em Um Bonde Chamado Desejo, ao final do qual, o terror de Blanche é representado fisicamente no palco por meio de aterradoras sombras sobre as paredes que compõem o cenário de seu quarto.

A representação da realidade segundo os parâmetros aqui descritos está intimamente ligada à percepção épica; nela está contida a abertura para a exploração das diferentes nuanças por meio da qual se estrutura a percepção do real (em vista disso, somos lembrados do conceito de Bakhtin de romancização $^{107}$, que não deixa de ser o formato épico, agora aliado a essa possibilidade de libertação dos cânones fixos). Assim, retorna-se à tese inicialmente exposta por Szondi, para quem uma das soluções à crise do drama (embora se possa argumentar que não se trata da única) é exatamente o voltar-se para o épico, e, mais ainda, que essa solução é imposta pelas contingências históricas das épocas em questão, na renovação do olhar lançado sobre a realidade.

O que se pode identificar é uma certa confluência entre o desenvolvimento do gênero do romance e as inovações técnicas que o drama moderno e, no caso específico, que Tchékhov e Tennessee Williams apresentam. O realismo formal do romance do século XVIII, como explica Ian Watt $^{108}$, carrega como motivação algumas das mesmas tendências filosóficas que parecem atuar sobre esses dramaturgos e que, até boa parte do século XX, formavam a base do pensamento ocidental. A valorização do olhar científico, impessoal e objetivo, condizente também com as relações econômicas do capitalismo, entre empregadores e empregados, se manifesta nessa tentativa de imparcialidade, característica tanto do romance quanto dos textos em questão. A ausência de vilões e da estreita categorização entre o bem e o mal é também reflexo de uma tentativa de imparcialidade - muito embora seja possível imaginar, especialmente no caso de Tennessee Williams, quais os lados mais bem quistos pelos autores.

A mudança mesma de foco da esfera interpessoal para aquela de uma totalidade circunstancial exprime uma visão cartesiana do homem, visto que este existe somente como intercruzamento de diversas forças externas ${ }^{109}$ a ele. Sua esfera de ação potencial se desloca do mundo externo para o

107107 (Org.) SARRAZAC, J.P.2012. p. 167.

${ }^{108}$ WATT, Ian; A Ascensão do Romance. São Paulo: Companhia das Letras. 2007.

${ }^{109}$ LUKÁCS, G. 1965. Idem. 
mundo interno, resultando tanto no cogito ergo sum, quanto, no caso formal do drama, no deslocamento do conflito externo para a interioridade das personagens. Nas peças analisadas, o conflito está contido no embate interno do homem com seu exterior: Raniévskaia e sua família lutando internamente contra a perda de seu jardim, Sta. Hardwicke-Moore, contra a aceitação de sua condição objetiva de existência e, também, o Homenzinho, que tenta não sucumbir à rotina massacrante do trabalho operário, como seu antecessor russo.

Se, por um lado, essas semelhanças apontam para uma crescente característica épica na dramaturgia dos fins do século XIX e meados do século XX, por outro lado, aponta também para um movimento cultural maior, no qual a tendência liberal de pensamento, junto com o aparato cultural que a sustentou, começa a ser questionada quanto à sua eficiência, apesar da manutenção de seus valores. 


\title{
2. As Três Irmãs e Um Bonde Chamado Desejo: contextos em diálogo
}

\begin{abstract}
Williams pictures a society on the turn. Not for nothing was Chekhov his favorite playwright. The Southern setting of most of his plays suggests a culture whose past is no longer recoverable, except as myth, and whose future represents the threat of dissolution. Language has been evacuated by meaning, ironised by time. History has swept on by.
\end{abstract}

BIGSBY, C.W.E $E^{110}$.

Como visto no capítulo anterior, as formas dramáticas que Tennessee Williams e Anton Tchékhov empregam guardam diversas semelhanças, muitas delas ocasionadas pelos recortes temáticos pelos quais optaram, que fazem referência a um movimento maior dentro da cultura dos séculos XIX e XX. Os dois pilares que sustentam o pensamento romântico, visto pela perspectiva lukacsiana como paradigma ${ }^{111}$, o historicismo e o individualismo, além de serem a base para a própria formulação estrutural das peças, cujo centro de importância muda do conflito externo para interno e do plano micro do enredo para o macro das situações dramáticas, condicionam também o material subjetivo das peças.

A epígrafe que abre este capítulo explicita algo da natureza desse material, para o qual não importam as histórias pessoais de seus personagens senão como forma metonímica de representação de um estrato social específico e suas tensões de posição, que reverberavam na cultura como um todo. Diferentemente do drama clássico, no qual o herói deveria ser um símbolo positivo da

110 BIGSBY, Christopher W. E. Modern American Drama 1945 - 2000. Edição para Kindle. Cambridge: Cambridge University Press, 2000.

Tradução:

Williams retrata uma sociedade em transição. Não por nada era Tchékhov seu dramaturgo preferido. O cenário sulista da maioria de suas peças sugere uma cultura cujo passado não é mais resgatável, senão como mito, e cujo futuro representa a ameaça de dissolução. A linguagem foi evacuada de significado, ironizada pelo tempo. A história prosseguiu sem eles.

${ }^{111}$ LUKÁCS, G. 1965.

Lukács afirma que o drama moderno é burguês, historicista e individualista: burguês por estar inserido numa cultura burguesa e se sustentar sobre valores que a burguesia usara para se opor aos remanescentes feudais. Esses valores compõem a base do paradigma romântico de pensamento, o movimento burguês por excelência. Segundo Lukács, os ideias que sustentam o paradigma romântico são os mesmos que animaram a Revolução Francesa. 
humanidade, nestas peças os personagens possuem determinadas características de classe que implicam na perda do caráter - embora sempre ilusório - de atemporalidade e universalidade. O embate entre classes em decadência e ascensão torna-se conteúdo latente das peças; ele não é afirmado diretamente, mas se manifesta por meio das existências pessoais de seus protagonistas.

Essa temática é constante nas peças longas de Tchékhov e aparece, de maneira similar, nas peças do início da carreira de Tennessee Williams, transfigurada no embate entre as culturas do norte e do sul dos Estados Unidos. De certo, não se tratam de peças políticas, como seriam as de Górki ou de Clifford Odets, por exemplo; as disputas de classe que podem ser encontradas aqui aparecem como plano de fundo, evidenciadas por conflitos ideológicos. A referência a classes sociais, na verdade, toma forma retórica nas peças, que se utilizam dessas referências como forma de crítica por oposições - à mentalidade que estava em ascensão em suas épocas. O que pode ser identificado nas dramaturgias de Tchékhov e Tennessee Williams é uma insistência sobre o contraste entre paradigmas culturais, que, embora idealize muitas de suas características, se apresenta como uma maneira de evidenciar um processo de mudança.

As peças As Três Irmãs e Um Bonde Chamado Desejo encerram tais temáticas de maneira nítida e possibilitam incursões históricas importantes para o entendimento do contexto social de ambos os escritores.

Apesar dessa temática estar presente em diversos de seus textos, a análise recairá principalmente sobre As Três Irmãs ${ }^{112}$, de Anton Tchékhov, e Um Bonde Chamado Desejo ${ }^{113}$, de Tennessee Williams. Nessas peças, a disputa entre as classes sociais toma formas concretas, representadas pelas personagens: como as três irmãs Prózorov e Blanche DuBois, entendidas como paradigma de suas culturas, se confrontam com Natacha Ivánovna e Stanley Kowalski, sucumbindo lentamente às pressões pessoais e históricas que eles representam.

As Três Irmãs começou a ser escrita em 1899 e, após revisões, chegou aos palcos com o Teatro de Arte de Moscou em $1901^{114}$. A peça conta a história da família Prózorov, composta por três irmãs, Olga, Macha e Irina, e o irmão Andrei Sergueievitch, que mudara-se para uma cidade não

\footnotetext{
112 TCHÉKHOV, A.P. 2013.

${ }^{113}$ WILLIAMS, T. 2000.

${ }^{114}$ SENELICK, Laurence. The Chekhov Theatre. Cambridge: Cambridge University Press, 1997.
} 
especificada da província russa por ocasião da mudança de cargo no exército de seu falecido pai. Passou-se já um ano desde sua morte, e os Prózorovs ainda estão no campo sonhando com seu idílico retorno à Moscou, sua cidade natal.

Com exceção de Macha e seu marido, Fiódor Iliítch Kulíguin, todos vivem na mesma casa dentro da grande propriedade da família - indicativo da classe social da qual provém a nobreza russa $^{115}$-, acompanhados de um velho médico do exército e amigo da família, Ivan Romanovich Tchebutikin, e Anfisa, a velha babá da família. Raramente estes se encontram sozinhos na casa, com frequência recebem visitas de outros integrantes do exército, o barão Tuzenbakh, os tenentes Rodé, Fedotik e Solioni e o capitão Verchinin, que no primeiro ato acabara de chegar de Moscou com sua família, também de Natália Ivanovna, que a partir do segundo ato passa a morar com os Prózorovs por ter se casado com Andrei, e Ferapont, o surdo mensageiro do conselho regional da província. Cabe lembrar que os cargos do alto escalão do exército eram ocupados tradicionalmente pela nobreza e estes, em tempos de relativa paz, encontram-se em estado de completo ócio, como várias vezes menciona Tchebutikin.

Não há acontecimentos dramáticos na peça, como dita o estilo tchekhoviano. Existem sim várias subtramas amorosas, como o amor de Tuzenbakh e Solioni pela irmã mais nova, Irina, e o caso de Macha com Verchinin; novamente, porém, o foco central da peça está na situação global, não em suas pequenas histórias. "Chekhov changed the scale of what is called "an event" in drama. He changed the very object of theatre: instead of the "drama in life" "the drama of life" became the focus of his compositions." 116

Mesmo fatos que poderiam ser propulsores de ação, como o incêndio que acomete a cidade no terceiro ato, a tentativa de suicídio da esposa de Verchinin ou o duelo entre o Barão Tuzenbakh e Solioni do quarto ato ocorrem fora do âmbito do palco e surtem efeitos extremamente limitados no andamento do drama. De maneira geral, só ressaltam com ainda maior nitidez a estagnação das

\footnotetext{
${ }^{115}$ Cabe notar aqui que havia uma diferença qualitativa entre os graus de nobreza existentes na Rússia, que também se dividiam em duas hierarquias distintas, mas semi-equivalentes: a militar e a civil. A hierarquia militar, à qual pertence a família Prózorov, era considerada portadora de um prestígio um pouco maior do que a civil.
}

${ }^{116}$ SMELIANSKY, A. Chekhov at the Moscow Art Theatre. In. Org. GOTTLIEB, Vera, e Paul ALLAIN. The Cambridge Companion to Chekhov. Cambridge: Cambridge University Press, 2000. p.30.

Tradução:

“Tchékhov mudou a escala daquilo que se chama 'um evento' no drama. Ele mudou o objeto mesmo do teatro: em vez do 'drama na vida', 'o drama da vida' se tornou o centro de suas composições." 
personagens.

É interessante a afirmação do crítico Smeliansky a respeito das personagens tchekhovianas: "His characters are defined by the 'out-of-join' world that gave rise to new causes and effects in both life and drama ${ }^{117}$, , e pode ser estendida às personagens de Tennessee Williams também. Além de frutos das circunstâncias sociais e históricas às quais pertenciam os escritores, as personagens ainda podem ser entendidas como reflexos do mundo que as criou.

Diferentemente daquilo que ocorria no drama burguês, em que o personagem era livre para optar e agir, as personagens apresentadas por ambos os escritores são presas às suas circunstâncias, restando-lhes poucas, quando não nenhuma, opção de atuação. De certa maneira, é possível alinhá-las à corrente inaugurada por Georg Büchner em sua peça Woyzeck, em que primeiro se encontra um personagem totalmente submetido às urgências de suas circunstâncias e, apesar de seu final trágico, não surge nenhum vilão. Dessa perspectiva, as personagens tornam-se representativas de muito mais do que seres humanos individuais, expandindo seu potencial de significação para elementos metonímicos de classe. Agora desvinculadas do pleno mimetismo e das formalidades que o drama anterior impunha, encontram-se inseridas em um contexto histórico específico. Como explicitado por Smeliansky, as personagens aqui já não são compostas somente como instrumentos para o andamento do drama, nelas pode ser vislumbrado o mundo que lhes deu origem, um mundo em convulsões sociais.

${ }^{117}$ SMELIANSKY, A. Chekhov at the Moscow Art Theatre. In. Org. GOTTLIEB, Vera, e Paul ALLAIN. The Cambridge Companion to Chekhov. Cambridge: Cambridge University Press, 2000. p.30.

Tradução:

Suas personagens são definidas pelo mundo 'fora de eixo' que possibilitou o surgimento de novas causas e efeitos tanto na vida como no drama. 


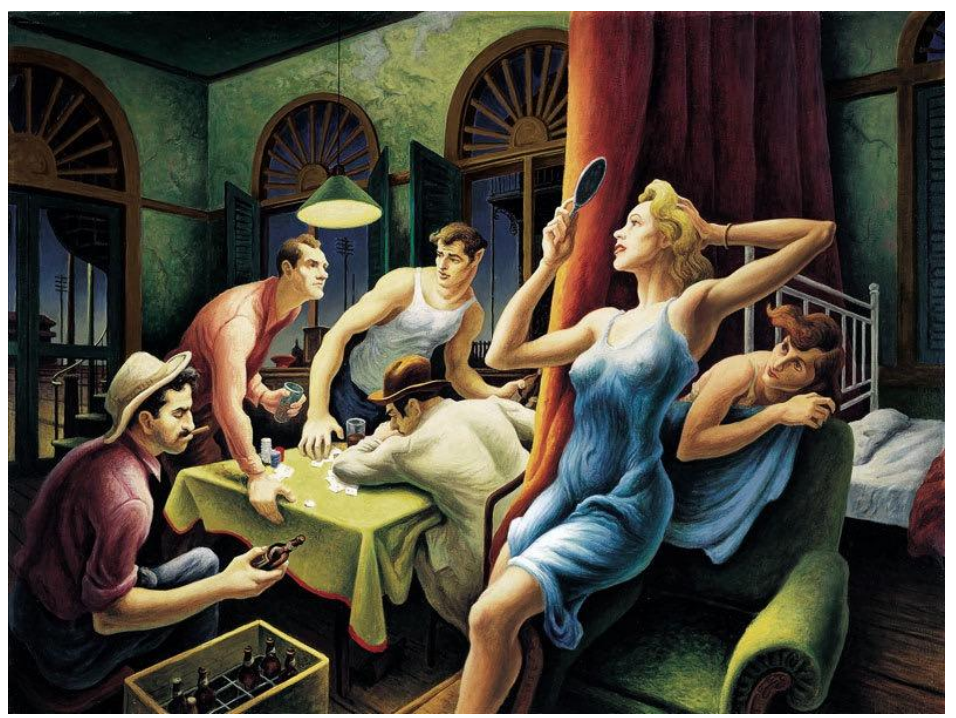

Fig. 1: Poker Night (a streetcar named desire). Thomas H. Benton, 1948. Foi encomendado ao pintor para ser utilizado no cartaz da peça.

A peça de Tennessee Williams, Um Bonde Chamado Desejo, data de 1947, e estreou nos palcos da Broadway no mesmo ano, sob direção de Elia Kazan, recebendo o Pulitzer Prize em $1949^{118}$. A ação se passa num bairro pobre de Nova Orleans, por onde passava um bonde chamado Desejo, e relata a visita de Blanche DuBois à sua irmã e seu marido, Stella e Stanley Kowalski. A família DuBois era dona de uma grande propriedade rural em Laurel, chamada Belle Rêve, que fora perdida por conta de inúmeras dívidas contratadas em função da morte de todos os familiares das irmãs. Com o desenrolar da peça, sabemos que Blanche foi expulsa de sua cidade natal após ter tido um caso com um de seus alunos. Ao lado dessas personagens centrais há Mitch, amigo e colega de trabalho de Stanley, com quem Blanche tenta se casar, Eunice e Steve, vizinhos dos Kowalskis, e Pablo, também um de seus colegas.

A relação de Blanche e Stanley, filho de um imigrante polonês de classe baixa, é bastante tensa desde o início. A vulgaridade de um entra em conflito com o ar de superioridade do outro, criando uma atmosfera de verdadeiro terror entre ambos.

STANLEY: When we first met, me and you, you thought I was common. How right you was,

${ }^{118}$ KOLIN, Philip. Tennessee Williams: A Guide to Research and Performance. Edição para Kindle. Westport: Greenwood, 1998. 
baby. I was common as dirt. You showed me the snapshot of the place with the columns. I pulled you down off them columns and how you loved it, having them colored lights going! And wasn't we happy together, wasn't it all okay 'till she showed here?

(Stella makes a slight movement. Her look goes suddenly inward as if some interior voice had called her name. She begins a slow, shuffling progress from the bedroom to the kitchen, leaning and resting on the back of the chair and them on the edge of the table with a blind look and listening expression. Stanley, finishing with his shirt is unaware of her reaction.)

And wasn't we happy together? Wasn't it all okay? Till she showed here. Hoity-toity, describing me as na ape. (He suddenly notices the change in her.) Hey, what is it, Stel? (He crosses to her. $)^{119}$

Blanche é incapaz de entender como sua irmã, provinda de família "tão culta e educada", como a personagem inúmeras vezes afirma, consegue viver com um homem tão rude quanto Stanley. "Don't

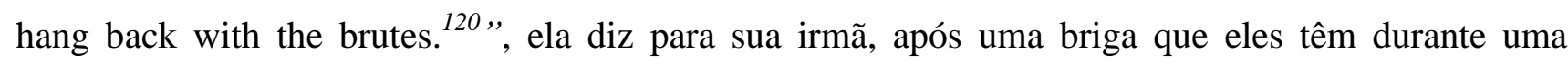
partida de pôquer.

BLANCHE: He acts like an animal, has an animal's habits! Eats like one, moves like one, talks like one! There's even something - sub-human - something not quite to the stage of humanity yet! Yes, something - ape-like about him, like one of those pictures I've seen in anthropological studies! Thousands and thousands of years have passed him right by, and there he is - Stanley Kowalsky - survivor of the stone age! (...) And you - you here - waiting for him! (...) Maybe we are a long way from being made in God's image, but Stella - my sister there has been some progress since then! Such things as art - as poetry and music - such kinds of new light have come into the world since then! In some kinds of people some tenderer feelings have had some little beginning! That we have to make grow! And cling to, and hold as our flag! In this dark march toward whatever it is we're approaching... Don't-don't hang back with the brutes! ${ }^{121}$

${ }^{119}$ WILLIAMS, T. 2000. p.541.

Tradução:

STANLEY: Quando nos conhecemos, eu e você, você achou que eu era comum. E como tava certa, garota. Eu era comum como a terra. Você me mostrou a foto do lugar com as colunas. Eu te tirei de cima daquelas colunas e como você amou isso, as luzes piscando! E a gente não era feliz junto, não estava tudo bem antes dela aparecer aqui?

(Stella faz um leve movimento. Seu olhar de repente se volta para dentro, como se uma voz interior tivesse chamado seu nome. Ela começa um progresso lento, arrastando-se do quarto para a cozinha, se apoiando primeiro na cadeira depois na beirada da mesa, com um olhar vazio e uma expressão atenta. Stanley está terminando de lavar sua camisa, não percebeu sua reação).

E não éramos felizes juntos? Não estava tudo bem? Até ela aparecer aqui. Toda metida, me chamando de macaco. (Ele de súbito percebe a mudança em Stella.) Ei, o que foi, Stel? (Vai em sua direção.).

${ }^{120}$ Ibidem. p.511.

Tradução:

Não fique para trás com os brutos. 
A situação se agrava quando o marido ouve sua fala, transformando sua incompreensão em puro ódio. Apesar da crueza com a qual é retratado, Stanley é extremamente dedicado à sua mulher e ao filho que ela carrega, teme perdê-los frente às investidas de Blanche, então livrar-se dela torna-se uma questão de sobrevivência a partir deste ponto.

(Stanley turns slowly back toward his wife and takes her clumsily in his arms.)

STANLEY: Stell, it's gonna be all right after she goes and after you've had the baby. It's gonna be all rigt again between you and me the way it was. You remember the way it was? Them nights we had together? God, honey, it's gonna be sweet when we can make noise in the night the way we used to and get the colored lights going with nobody's sister behind the curtains to hear us!

(Their upstairs neighbors are heard in bellowing laughter at something. Stanley chuckles.)

Steve an' Eunice...

STELLA: Come on back in. (She returns to the kitchen and starts lighting the candles on the white cake.). Blanche? ${ }^{122}$

${ }^{121}$ WILLIAMS, T. 2000. p.510-511.

Tradução:

BLANCHE: Ele age como um animal, tem os hábitos de um animal! Como como eles, se move como eles, fala como eles! Tem até algo de - subumano - algo que ainda não chegou bem ao estágio humano! Sim, algo - simiesco sobre ele, como uma dessas imagens que vi em - estudos antropológicos! Milhares e milhares de anos passaram direto por ele, e lá está Stanley Kowalski - sobrevivente da idade das pedras! (...) E você - você aqui - esperando por ele! (...) Talvez nós estejamos muito longe de sermos feitas à imagem de Deus, mas Stella - minha irmã - houve algum progresso desde então! Coisas como a arte - como a poesia e a música - esse tipo de nova luz apareceu sobre o mundo desde então! Em algumas pessoas, sentimentos mais tenros tiveram um pequeno início! E nós temos que fazê-los crescer! E nos agarrar a eles, e os carregarmos como nossa bandeira! Nessa marcha sombria rumo a onde quer que seja que nós estamos nos aproximando... não - não fique para trás com os brutos!

${ }^{122}$ Ibidem. p.538

Tradução:

(Stanley se volta devagar para sua mulher e a abraça desajeitadamente.)

Stell, vai ficar tudo bem depois que ela for embora e depois que você tiver o bebê. Vai ficar tudo bem de novo entre nós dois, como era antes. Você lembra como era antes? As noites que tínhamos juntos? Meu Deus, querida, vai ser incrível quando a gente puder voltar a fazer barulho durante a noite, fazer as luzes piscar sem a irmã de ninguém atrás da cortina para nos ouvir!

(Seus vizinhos de cima podem ser ouvidos gargalhando de alguma coisa. Stanley ri.)

Steve e Eunice...

STELLA: Entra aqui. (Ela volta para a cozinha e começa a acender as velas no bolo branco.) Blanche?’. 
A peça, contudo, não é histórica; a rivalidade que existe entre as classes nos sul dos Estados Unidos permanece até os tempos modernos, incorporada à identidade sulina. Como se verá com maiores detalhes adiante, o embate entre a cultura do sul e a do norte foi bastante agressivo, caracterizado por um senso de oposição que marcou fortemente as identidades locais. Desenvolveuse, a partir daí, um passado mitológico ao qual inúmeras gerações de artistas do sul fariam referência.

A partir das primeiras décadas do século $\mathrm{XX}$, surgiu na literatura americana aquilo que os críticos chamaram de Renascimento do Sul e Escola Gótica, e, apesar dos rótulos serem bastante questionáveis, como Carson McCullers afirma ${ }^{123}$, não deixam de apontar duas características essenciais sobre o conjunto da obra dos escritores sulinos: primeiro, que produziam obras que não se encaixavam no todo da literatura norte-americana, se distanciando em estilo e conteúdo das demais produções da época, e, segundo, que entre esses escritores havia certa coesão temática e estilística. Dadas as peculiares características da formação identitária da região, as questões a isso relacionadas teriam grande prevalência na literatura lá produzida, especialmente com o crescente contato com a cultura industrializada e globalizada do Norte. Carson McCullers, em seu livro The Mortgaged Heart $^{124}$, ao analisar a literatura produzida no sul, que também envolvia a análise de suas obras, várias vezes aponta para a recorrência de tais questões como tema, como também para a relação de dívida que ela acreditava existir entre os americanos e os realistas russos, entre os quais acreditava haver inúmeras semelhanças.

The writer's work is predicated not only on his personality but by the region in which he was born. I wonder sometimes if what they call the 'Gothic' school of Southern writing, in which the grotesque is paralleled with the sublime, is not due largely to the cheapness of human life in the South. The Russians are like the Southern writers in that respect. In my childhood, the South was almost a feudal society. 125

\footnotetext{
${ }^{123}$ MCCULLERS, Carson. The russian realists and southern literature. In. The Mortgaged Heart. Edição para Kindle. London: Penguin Books, 2008.

${ }^{124}$ Idem.

${ }^{125}$ Ibidem. LOC 4228

Tradução:

O trabalho do escritor não é determinado somente por sua personalidade, mas pela região na qual nasceu. Eu me pergunto se aquilo a que eles chamaram da escola de escrita 'gótica' do sul, na qual o grotesco está em paralelo ao sublime, não é
} 
Assim, Um bonde chamado desejo é uma peça que trata de temas atuais, que devem ser entendidos dentro do complexo contexto histórico no qual estão inseridos, pois a batalha ali apresentada teve seu início muito antes do momento em que foi escrita.

É interessante notar como a fortuna crítica americana, especialmente quando se refere às obras de Tennessee Williams, insiste nessa "herança do Sul” que o escritor carrega, reforçando os variados estereótipos que se desenvolveram em torno da "personalidade dos sulistas". Exemplos disso são inúmeros dentro da cultura americana, desde a visão mais realista e ponderada de William Faulkner e Flannerty O’Connor, às suas versões mais caricatas que se encontram, por exemplo, em Hollywood o filme Meia Noite no Jardim do Bem e do Mal e Uma Canção para Bobby Long talvez sejam ótimas ilustrações dessa visão caricatural. Independentemente dessa visão ser verídica ou fictícia, a sua recorrência sugere que tenham forte presença no imaginário norte-americano.

É possível perceber em ambas as obras, então, a convivência intensa de representantes de classes sociais historicamente antagônicas - como a alta nobreza rural em decadência e a burguesia comercial em ascensão e o patriarcado rural americano e o trabalhador urbano. Mais do que as distinções objetivas de classe, tornam-se motores propulsores das obras as tensões geradas pelas filosofias ontológicas e as perspectivas morais e econômicas dos diferentes grupos, sempre em versões "fictícias", como se viu acima.

A idealizada cultura sulina norte-americana, com suas maneiras emulativas das aristocracias europeias, seu pendor para a polidez, para a "alta cultura" e sua aversão às vulgaridades do dinheiro e da competição, estabelece um forte contraste quando colocada em cena junto ao estereótipo do bruto Stanley Kowalski, cujas características evocam a cultura materialista do burguês filisteu. Tennessee Williams carrega de referências diversas de suas falas, mostrando sua excessiva preocupação com o dinheiro, com suas ambições no trabalho e com o caráter de agente que mantém como ideal. Todo o andamento do drama está centrado sobre a tensão que se estabelece entre esses dois personagens, Stanley e Blanche, e suas diferentes perspectivas.

Tanto nas figuras das irmãs de Tchékhov quanto nas de Tennessee, é o mundo "nobre" que existe como referência, com sua alta cultura, suas maneiras polidas e sua aversão à agressividade da

fortemente devida à barateza da vida humana no Sul. Os russos são como os escritores do Sul nesse respeito. Durante a minha infância, o Sul era uma sociedade quase feudal. 
corrida de $\operatorname{ratos}^{126}$ que rege o novo mundo capitalista. Para elas, como também para Andrei Prózorov, a inserção na nova ordem econômica e, subsequentemente, cultural, é bastante difícil. Vêse Irina e Olga Prózorov exaltando o trabalho em oposição à ociosidade característica da nobreza e, no entanto, ao se juntarem ao contingente de trabalho de fato, não só percebem que aquilo não lhes traz qualquer satisfação, como haviam sonhado, mas também que implica em cansaço, pura exaustão. Blanche DuBois também passa por processo similar: ela entende a necessidade por dinheiro e se emprega como professora em uma escola local - como Olga e, depois, Irina -, porém, nem mesmo em um ambiente onde a cultura deveria ser bem acolhida, sente-se bem e útil. Blanche também está cansada e exausta de tentar se sustentar, não só financeiramente, mas como integrante dessa cultura desaparecida e idílica. Todas elas buscam acolhimento e descanso, projetando-os na possibilidade de um casamento oportuno que jamais acontece.

Muitos críticos, como Krasner e Bigsby ${ }^{127}$, insistem na característica recorrente de personagens de Tennessee como aqueles que não pertencem a lugar nenhum. Comentários similares também foram feitos às personagens de Tchékhov, como personagens deslocados. Essa qualidade de não pertencimento pode ser inferido e deriva mais de questões sociais do que de questões subjetivas. É evidente, através da construção de personagens como Blanche e as três irmãs de Tchékhov, que tal sensação se faz presente em razão do caráter transitório e decadente dos paradigmas culturais e econômicos aos quais se atrelam. O mesmo já não pode ser dito a respeito de Stanley nem de

${ }^{126}$ WILLIAMS, T. 2000. p.555.

Tradução:

STANLEY: Drew to na inside straight and made ir, by God.

PABLO: Maldita sea to suerte!

STANLEY: Put it in English, greaseball.

PABLO: I am cursing your rutting luck.

STANLEY (Prodigiously elated): You know what luck is? Luck is believing you're lucky. Take at Salerno. I believed I was lucky. I figured that 4 ou of 5 would not come through but I would... and I did. I put that down as a rule. To hold front position in this rat-race you've got to believe you are lucky.

STANLEY: Puxei a carta direto do monte e consegui!

PABLOS: Maldita sea tu suerte!

STANLEY: Em inglês, seu sebento.

PABLO: Estou xingando sua sorte.

STANLEY (Prodigiosamente): Sabe o que é a sorte? Sorte é acreditar que você tem sorte. Como em Salerno. Eu acreditei que tinha sorte. Sabia que para cada cinco, quatro não sobreviveriam, mas eu sobreviveria. E sobrevivi. É assim, para manter a primeira posição nessa corrida de ratos, você precisa acreditar que tem sorte.

${ }^{127}$ KRASNER, David, ed. A Companion to Twentieth entury American Drama. Malden: Blackwell Publishing, 2005. —. American Drama 1945 - 2000. Edição para Kindle. Malden: Blackwell Publishing, 2006.

BIGSBY, Christopher W. E. Modern American Drama 1945 - 2000. Edição para Kindle. Cambridge: Cambridge University Press, 2000. 
Natasha, personagens referentes aos sistemas dominantes.

O caso de personagens como Andrei e Stella DuBois / Kowalski é diferente: são eles que fazem a ligação com os representantes da nobreza. Ambos são casados com personagens externas aos seus círculos sociais e, assim, forçam nas peças a convivência muito próxima entre as classes. Stella é casada com um homem que representa nitidamente a mentalidade do self-made man tradicional americana. Stanley Kowalski, além de pouco educado, é um indivíduo determinado a ascender na escala social, que trabalha duro e, como ele mesmo diz, tem que ser forte para manter-se à frente na corrida.

(He hurls a plate to the floor.)

STANLEY: That's how I'll clear the table! (He seizes her arm.) Don't ever talk that way to me! "Pig - Pollack - disgusting - vulgar - greasy!" - them kind of words have been on your tongue and your sister's too much around here! What do you two think you are? A pair of queens? Remember what Huey Long said - "Every Man is a King!" And I am the king around here, so don't forget it! (He hurls a cup and saucer to the floor.) My place is cleared! You want me to clear your places? ? $^{128}$

STANLEY: I am not a Polack. People from Poland are Poles, not Polacks. But what I am is one hundred percent American, born and raised in the greatest country on earth and proud as hell of it, so don't ever call me a Polack. ${ }^{129}$

Para ele, é incompreensível aquilo que enxerga como fraqueza e uma tendência à falsidade moral e à decepção em Blanche - isso fica bastante claro quando Stanley explica que não poderia deixar seu

${ }^{128}$ WILLIAMS, T. 2000. p.537.

Tradução:

(Ele arremessa um prato no chão.)

STANLEY: é assim que eu vou tirar a mesa! (Ele segura seu braço.) Nunca fale comigo desse jeito! "Porco - Polaconojento - vulgar - engordurado!" - essas palavras tem andado demais na sua boca e na da sua irmã! O que vocês duas acham que são? Duas rainhas? Lembra do que Huey Long disse - "Todo Homem é um Rei!” E eu sou o rei aqui, então não se esqueça! (Ele arremessa uma xícara e um pires no chão.) Limpei meu lugar! Quer que eu ajude a limpar o de vocês?

${ }^{129}$ WILLIAMS, T. 2000. p.539.

Tradução:

STANLEY: Eu não sou polaco. Pessoas da Polônia são polonesas, não polacas. Mas o que eu sou é cem por cento americano, nascido e criado no melhor país do mundo e com muito orgulho, então nunca mais me chame de polaco. 
melhor amigo ser enganado por sua cunhada."STANLEY: you're goddamn right I told him! I'd have that on my conscience for the rest of my life if I knew all that stuff and let my best friend get caught!"130

Natacha Ivanovna tampouco se entende com Olga e as demais irmãs, sua perspectiva é mais pragmática e severa do que a delas. Tchékhov a coloca em cena buscando velas acesas inutilmente, numa atitude bastante mesquinha:

NATACHA: O que está fazendo, Andriucha ${ }^{131}$ ? Está lendo? Não é nada, é que... (continua andando, abre uma porta, depois a fecha) queria ver se não ficou alguma luz acesa.

ANDREI (entra com um livro na mão): Que é, Natacha?

NATACHA: estou verificando se apagaram todas as velas... é carnaval e os criados estão muito agitados, todo cuidado é pouco. Ontem à meia-noite entrei na sala de jantar e havia uma vela acesa. E não como saber quem a acendeu. (deposita a vela.) Que horas são? ${ }^{132}$

Sua relação com os criados da casa também se mostra questionável, como quando grita contra a presença de Anfisa, a velha senhora, antiga babá dos Prózorov, já incapaz de exercer sua função e, portanto, inútil aos olhos de Natacha. Olga não sabe sequer como responder àquilo que ela enxerga como falta de humanidade.

OLGA (não lhe presta atenção): Deste quarto não se vê o incêndio. Aqui está tudo tranquilo.

NATACHA: Sim... Estou muito despenteada... (Diante do espelho.) Dizem que engordei... Não é verdade! Nem um pouco! E Macha está dormindo, cansou-se, coitada... (A Anfisa, fria) quando estou aqui não se atreva a ficar sentada! Levante-se, saia daqui! (Anfisa sai. Pausa.) Não posso entender por que você mantém essa velha.

OLGA (perplexa): Desculpe, tampouco eu entendo...

NATACHA: Não há razão para ela estar aqui. É uma camponesa, e seu lugar é na aldeia. Para que miná-la? Gosto quando está tudo em ordem na casa. Aqui não há lugar para gente inútil.

${ }^{130}$ WILLIAMS, T. 2000. p.534.

Tradução:

STANLEY: Pode ter absoluta certeza que eu contei! Isso ficaria pesando na minha consciência pelo resto da minha vida se eu soubesse de tudo isso e deixasse meu melhor amigo ser enganado!

${ }^{131}$ Apelido para Andrei

132 TCHÉKHOV, A.P. 2013.p.24. 
(Acaricia o rosto de Olga) Está cansada, pobrezinha. Nossa diretorinha está cansada. Quando a minha Sofotvhka crescer e entrar para o ginásio, sei que terei medo de você.

OLGA: Eu não serei diretora.

NATACHA: Mas você será eleita, Oliuchka. Já está resolvido.

OLGA: Recusarei. Não posso... Não iria conseguir... (Bebe água) Há pouco você foi muito grosseira com a babá. Perdoe-me, mas eu não posso suportar isso... fiquei com a vista turva...

NATACHA (Agitada) Perdoe-me, Olia querida, não quis afligi-la. (Macha levanta-se, pega o travesseiro e retira-se furiosa)

OLGA: Compreenda, querida, que talvez nós tenhamos sido educadas de modo estranho, mas eu não posso suportar isso. Esse tipo de comportamento me deprime... eu fico doente

NATACHA: Bem, me perdoe. (Beija-a)

OLGA: A mínima grosseria, uma palavra menos delicada, me altera...

NATACHA: Pode ser que às vezes eu fale demais. Mas você tem que reconhecer, querida: a babá bem que poderia ter ficado na aldeia...

OLGA: Ela está conosco há trinta anos.

NATACHA: Mas já não pode mais trabalhar. Ou sou eu quem não entende ou é você que não quer me entender. Ela não serve para trabalhar; só dorme ou fica sentada.

OLGA: então que fique sentada.

NATACHA (Admirada): Ficar sentada? Mas é uma criada! (Desata a chorar) Não a compreendo, Olga. Tenho uma babá, uma ama de leite, uma criada, uma cozinheira... então para que precisamos dessa velha? Para quê? (Ouve-se o repicar dos sinos)

OLGA: Eu envelheci dez anos esta noite.

NATACHA: Temos de tratar desse assunto, Olga. Você está no liceu e eu fico aqui; você dá aula, eu cuido da casa. E se eu disser algo dos criados, sei o que estou dizendo; sei o que estou di-zen-do... Assim sendo, amanhã não quero mais essa velha ladra, essa decrépita!... (Bate os pés) Não quero ver essa velha bruxa! E parem de me irritar! Entenderam?... (controla-se) Está vendo? Se você não mudar para o andar de baixo, vamos brigar sempre. É horrível. ${ }^{133}$

Através do excerto transcrito acima, torna-se visível o ponto ápice de tensão entre as duas culturas ali representadas, como também a consciência que Natacha e Olga têm de que não há nenhuma chance de entendimento entre elas. Falam de um mesmo tema, mas de pontos de vista tão distintos que a própria convivência de uma com a outra se torna impossível. Natacha, agora detentora

${ }^{133}$ TCHÉKHOV, A.P. 2013. p.41-42. 
do poder, pois lentamente assume o controle dentro da casa, expulsa Olga, suas irmãs, e, consequentemente, o ponto de vista que estas representam, pondofim ao conflito."MACHA: O que fazer? Se nos enxotam temos de ir. (A Irina). Não é Bóbik ${ }^{134}$ que está doente, e sim ela [Natacha]... aqui! (Aponta com o dedo a testa.) É uma burguesinha!"135

Da mesma maneira, por meio da força e da imposição do poder, Stanley vence a perspectiva de Blanche. Ela tenta se explicar, comunicar o seu ponto de vista, mas não há ali meios de comunicação, e na falta de meios, fala-se com a força. O estupro que sofre de Stanley é bastante simbólico ${ }^{136}$ nesse sentido e quase inevitável, como ele mesmo diz: "We've had this date with each other from the beginning!" 137 .

É bastante curioso notar também que os embates culturais presentes nas peças são levados à cena com seus resultados fixos desde o início, os destinos traçados de maneira irrevogável. Não à toa, a representante da antiga cultura nobre sulista é estuprada pelo representante da cultura antagônica e, depois, levada ao manicômio; tampouco, é gratuito em Tchékhov as irmãs lentamente perdendo espaço em sua própria casa para Natasha e seus filhos - primeiro, Olga é designada a dividir quarto com sua irmã, Irina, depois, elas são enviadas para morar no andar de baixo da casa, até que,

${ }^{134}$ Primeiro filho de Natacha e Andrei.

${ }^{135}$ TCHÉKHOV, A.P. 2013. .p.36.

${ }^{136}$ Sobre a importância e o significado desta cena para a peça, Tennessee Williams explica em uma de suas cartas:

The rape of Blanche by Stanley is a pivotal, integral truth in the play, without which the play loses its meaning, which is the ravishment of the tender, the sensitive, the delicate by the savage and brutal forces in modern society. It is a poetic plea for comprehension. I did not beg the issue by making Blanche a totally 'good' person, nor Stanley a totally 'bad' one. But to those who have made some rational effort to understand the play, it is apparent that Blanche is neither a 'dipsomaniac' nor a 'nynphomaniac' but a person of intense loneliness, fallibility and a longing which is mostly spiritual for warmth and protection.

Tradução:

O estupro de Blanche por Stanley é uma verdade integral e pivotal da peça. Sem a qual ela perde seu significado, que é a violentação do tenro, o sensível, o delicado pelas forças selvagens e brutais da sociedade moderna. É um apelo poético para a compreensão. Eu não sobrecarreguei o assunto fazendo de Blanche uma pessoa totalmente 'boa' nem de Stanley uma pessoa totalmente 'ruim'. Para aqueles que fizeram um esforço racional para entender a pela. É aparente que Blanche não é nem dipsomaníaca nem ninfomaníaca, mas uma pessoa de intensa solidão, falibilidade e um desejo essencialmente espiritual por calor e proteção.

WILLIAMS, T. - . The Selected Letters of Tennessee Williams. Vols. II ( 1945 - 1957). New York: New Directions, 2004. p. 355.

${ }^{137}$ WILLIAMS, T. p.555.

Tradução:

Nós tínhamos este encontro marcado desde o início! 
finalmente, Olga passa a morar na escola onde leciona, com sua babá, Anfisa.

O caráter do inevitável serve para reforçar, como exposto no capítulo 1, a percepção do homem condicionado por suas circunstâncias sociais. "Men are but pawns, their will is but their possible moves, and it is what remains forever alien to them (the abstractum) which moves them." ${ }^{138}$ A citação de Lukács pode ser vista como resumo das personagens neste tipo de drama. Não há, para elas, qualquer possibilidade de ação sobre o fim que terão, o que está em jogo é algo muito além delas, são as variáveis histórico-sociais que as definem. Assim, o fim das peças já está anunciado desde seu princípio, ou melhor, desde sua própria estruturação.

É interessante notar como o conteúdo em questão parece absolutamente adequado à forma, ambos provenientes de uma só visão ontológica, e como os elementos fornecidos pelos autores, como os casos de amor não correspondidos, as brigas e discussões, a própria movimentação dos personagens sobre o palco, tudo, corrobora a tese central dessa situação de mudanças paradigmáticas.

Lukács defende também que o drama moderno, pela visão circunstancial que tem do homem, adquire um característico relativismo, provindo da possibilidade de justificativa externa que todos os seus atos têm. Desse relativismo também decorre a impossibilidade de comunicação que se vê entre os diversos indivíduos que já não guardam nada em comum. Se não podem ser vistos como mônadas ${ }^{139}$, somente como expressão de algo que lhes é externo, o isolamento parece ser inevitável, porque seu potencial de expressão "essencial" desaparece. Assim, também, desaparece a possibilidade de empatia e, com isso, na solidão, os diálogos se fragmentam.

The more lonely men in drama become (and the development is ever more in this direction, or at least toward awareness of it), the more the dialogue will become fragmented, allusive, impressionistic in form rather than specific and forthright. ${ }^{140}$

\footnotetext{
${ }^{138}$ Lukács, G. 1965.p.151
}

Tradução:

Os homens não passam de peões, sua vontade, nada mais do que seus possíveis movimentos, e é aquilo que será para sempre estranho a eles (o abstractum) o que os move.

${ }^{139}$ Referenciar a citação de BITSILLI, página 27 do capítulo 1.

${ }^{140}$ LUKÁCS, G. 1965.p. 163. 
O que transparece nas peças é mais do que o movimento natural das sociedades, a transição de suas elites foi um fenômeno bastante marcante na cultura russa e na cultura norte-americana. Em ambos os países, não obstante as diferenças que existem entre eles, um processo análogo ocorreu, resultando em referências similares dentro do âmbito de suas artes. É nesse sentido que se pode encontrar um substrato mais firme para a comparação entre a produção de Tchékhov e de Tennessee Williams. Não se trata só da utilização de recursos dramatúrgicos parecidos por pura preferência estética, especialmente se, novamente, a relação entre forma e conteúdo é entendida dialeticamente. É possível delinear na história de ambos os países um processo análogo que, quando tematizado, impele a forma, levando ambos os dramaturgos a uma aproximação formal.

É essencial perceber o caráter idealizado dado às diferentes culturas de classe; ele sugere uma crítica voltada a ambos os lados do conflito. Formalmente, nenhum dos personagens se apresenta como inteiramente negativo, sendo circunstancialmente justificado; no entanto, a ausência de personagens negativos implica na ausência de personagens positivos - se não efetuam escolhas, pois seus atos são condicionados por fatores externos, tampouco é deles seus méritos. Tais ausências permitem pensar estas peças como críticas frente à situação total que trazem, entendimento também corroborado pela característica ausência de soluções aos problemas levantados. Deste modo, o exagero dos traços de classe encontrados em ambos os dramaturgos pode ser compreendido como uma forma retórica de trazer esse embate e os contrastes entre as culturas que estão em transição.

Para melhor entender as questões históricas, econômicas e culturais que aqui se encontram, cabe uma breve análise histórica de cada um dos países, com escopo limitado à comparação de regiões e tempos relevantes à formação dos autores: a Rússia provincial do século XIX e o Sul estadunidense dos séculos XIX e XX.

A perda de espaço da nobreza, em ambos os casos, tem seus fundamentos numa mudança global das estruturas econômicas: a transição do sistema capitalista mercantil para o sistema capitalista industrial. Frente a isso, é plausível relacionar o ato de extrema agressão que Stanley

Tradução:

Quanto mais solitários os homens do drama se tornam (e o desenvolvimento está cada vez mais nesta direção ou, no mínimo, rumo à percepção disto), mais o diálogo se torna fragmentado, alusivo, impressionista em sua forma, ao invés de específico e assertivo. 
impõe sobre Blanche àquilo que representou a Guerra de Secessão americana, especialmente em se tratando Tennessee de um escritor do sul dos Estados Unidos.

Pierre Bourdieu, em seu ensaio "Condição de Classe e Posição de Classe”, oferece as ferramentas para a comparação.

Levar a sério a noção de estrutura social supõe que cada classe social, pelo fato de ocupar uma posição historicamente definida e por ser afetada pelas relações que a une às outras partes constitutivas da estrutura, possui 'propriedades de posição' relativamente independentes de propriedades intrínsecas como por exemplo um certo tipo de prática profissional ou de condições materiais de existência. ${ }^{141}$

A partir de seu conceito de posição de classe, é possível estabelecer linhas comparativas entre classes sociais diferentes, mas que guardam entre si similaridades de posição, ou seja, cujas relações com as demais classes são semelhantes. Optou-se pela utilização desse conceito pois, embora as classes da nobreza rural russa e a da alta burguesia rural americana sejam intrinsecamente diferentes, durante os períodos de mudança econômica pelas quais passaram, cada uma a seu modo, mantiveram relações similares com a classe burguesa ascendente e dominante. Nos recortes abordados, torna-se explícito que o espaço que ocupam na história é transitório, pois o mundo sobre o qual se fundamentam é, paulatinamente, substituído por outro que as nega.

A estrutura social presente no sul dos Estados Unidos até meados do século XIX é bastante característica: grandes latifúndios de agroexportação voltados ao mercado externo, chefiados por uma elite proprietária branca, sustentados pela mão de obra de escravos africanos, com uma pequena camada de brancos não proprietários trabalhadores que atuavam em áreas interditadas aos escravos.

Escravista, estratificada, com sistemas de comunicação peculiares entre a classe dominante e a classe servil, qualitativamente distintos dos que existiam no norte, as colônias do sul singularizam-se. Essas características aparecerão marcadamente em seu pensamento político, especialmente quando unidas à pressão exercida sobre os sulistas pelos Yankees a favor da abolição da escravidão. Em praticamente nenhum momento, a elite do sul defenderá a igualdade entre todos os homens, e seu

${ }^{141}$ BOURDIEU, Pierre. A Economia das Trocas Simbólicas. São Paulo: Editora Perspectiva, 2005. 
conceito de democracia será sempre o presente no pensamento grego, retomado pelo liberalismo clássico: a democracia dos homens bons.

Bastante representativo da cultura do sul é, também, sua identificação com as aristocracias europeias - as colõnias do sul haviam sido o centro das relações entre os Estados Unidos e a Inglaterra, de forma que a elite, em boa parte, era filha da cultura inglesa. $\mathrm{O}$ colono americano não pertencia a nenhuma nobreza e, no entanto, no sul, acreditava-se nobre. Conforme o proprietário enriquecia, adotava costumes, trejeitos e ideais aristocráticos.

\begin{abstract}
Tocqueville in part is responsible. His (and others') writings about the end of the ancien régime in France made it easy for the next generation to treat the American Civil War and the abolition of slavery as the cataclysmic end of an old order. Aiding and abetting the historian, too, was the inclination of many after the war to romanticize or to demonize life in the good (or bad) old days before 1861.142
\end{abstract}

Vale pontuar o caráter paradoxal do papel dos colonos do sul norte-americano. No geral, os grandes proprietários, muito diferentemente da nobreza europeia, tinham começado sozinhos, com pequenos pedaços de terra e, aos poucos, ascendido na escala social.

Muitas hipóteses podem ser levantadas acerca das razões pelas quais os colonos adotaram tal caráter: a influência do movimento romântico, que se estabelecia na Europa, pode ter contribuído para a adesão à identidade Cavalier - muitas culturas tentaram adaptar suas próprias histórias aos formatos em voga na época, como o Brasil durante a fase indianista da literatura. Ao mesmo tempo, cabe considerar a posição de George Steiner quanto a necessidade pela busca de passados mitológicos exibida pelas sociedades ${ }^{143}$ e o fato desta se tratar de uma sociedade que se construía em

${ }^{142}$ MOLKE-HANSEN, David. "Between Plantation and Frontier: The South of William Gilmore Simms." In: William Gilmore Simms and the American Frontier, por John C. GUILDS. Georgia: University of Georgia Press, 1997.

Tradução:

Em parte, Toqueville é o responsável. Os seus (e de outros) escritos sobre o final do Antigo Regime na França facilitaram que a próxima geração tratasse a Guerra Civil Americana e a abolição da escravidão como o final cataclísmico da velha ordem. Auxiliando e incitando o historiador, também, havia a inclinação de muitos, após a guerra, a romantizar ou demonizar a vida nos bons (ou maus) e velhos tempos de antes de 1861.

143 "Cada nova era histórica se espelha na imagem e na mitologia ativa de seu passado ou de um passado emprestado de outras culturas. Ela põe à prova, em contraste com esse passado, seu sentido de identidade, de regresso ou de novas 
oposição ao norte. Desde a Guerra Civil, o sul enxergara seu ideal no tempo passado, e sua luta não era a de construção de uma sociedade, como o norte, mas de reconstrução daquela ordem idealizadamente aristocrática que lhes parecia perfeita.

É esse falseamento de um passado e de uma herança comportamental que fascinará tantos escritores do sul, especialmente no que diz respeito à incongruência entre a imagem que projetavam e as circunstâncias reais da vida local. É essa não conformidade também que a personagem Blanche DuBois guarda em si e que Stanley Kowalski tenta desmascarar:

STANLEY: Lie Number One: All this squeamishness she puts on! You should know the line she's been feeding to Mitch. She thought she had never been more than kissed by a fellow! But Sister Blanche is no lily! Ha-ha! Some lily she is! ${ }^{144}$

STANLEY: Well, so much for being such a refined and particular type of girl. (... $)^{145}$

A desconfiança crescente de Kowalski também está marcada nas diversas maneiras com as quais a personagem se refere a Blanche, como chamando-a de dame Blanche, lady Blanche, Sister Blanche, sempre de maneira bastante irônica.

É interessante notar que, como alguns historiadores afirmam, a imagem da aristocracia algodoeira sulina havia fornecido coesão aos homens de elite do sul, que pouco tinham em comum, senão a defesa da escravidão e a sensação de que estavam ameaçados pelas demais regiões do país ${ }^{146}$.

realizações. Os ecos pelos quais uma sociedade procura determinar o alcance, a lógica e a autoridade de sua própria voz." STEINER, George. No Castelo do Barba Azul. São Paulo: Companhia das Letras, 1991.

${ }^{144}$ WILLIAMS, T. 2000. p.530

Tradução:

STANLEY: Mentira número um: todos esses melindres que ela demonstra! Você precisava ver como ela tem enrolado o Mitch. Você imaginaria que ela nunca foi nem beijada por um rapaz! Mas a irmã Blanche não é nenhuma florzinha! Haha! Bela flor ela é!

${ }^{145}$ Ibidem. p.531.

STANLEY: Bom, belo tipo refinado e particular de moça.

146 "Many of these regions had little in common except na adherence to the slave system and a general feeling of being threatened by forces in the rest of the country."

Tradução: 
Por outro lado, aquilo mesmo que os uniu pode ser compreendido como uma das razões de seu descompasso futuro: impelidos pela ideologia nobre, ao se confrontarem com a nova ordem econômica (capitalismo industrial), não conseguem se adaptar e afundam em dívidas.

Outro elemento importante do sul era seu caráter agrário. Muito diferente do norte, que já havia passado por um processo de urbanização, o sul só começará a se desvincular sutilmente do campo após a Guerra de Secessão. Dessa forma, insistiam também sobre a validade do seu vínculo à natureza. Essa tendência a adotar a natureza como parâmetro moral de sua sociedade ${ }^{147}$ pode ser inferida como influência dos românticos alemães, como Grimm. Mas deve-se manter em mente que as escolhas feitas eram sempre condicionadas pela oposição à cultura do norte; é natural, portanto, que optassem por elementos exclusivos de sua região.

É através da pressão dessa oposição que se deve entender o caráter bastante hiperbólico do qual eram revestidos alguns trejeitos sociais adotados pela elite sulista. Na literatura do sul, especialmente em escritores como Tennessee Williams, William Faulkner, Carson McCullers e Flannerty O'Connor, esses elementos reaparecem com frequência e não sem menção à estranha mistura de hipocrisia e desespero que deles parece transparecer. Com as constantes mudanças econômicas desaparecem as bases objetivas que sustentavam muitos de seus costumes, e tem início um processo cada vez mais idealizado de afirmação de suas peculiaridades culturais. Quando já não há meios econômicos para diferenciá-los das demais classes, sobrecarregam de significado os elementos culturais que os fazem distintos. É importante, assim, perceber as relações que as antigas classes abastadas do sul estabeleciam com as demais classes sociais e também com os contingentes Yankees da sociedade, que se tornavam o modelo dominante de cultura. São tensões provindas da posição dessa classe que aparecem como tema subjacente nos textosde Tennessee.

Por outro lado, cabe lembrar que muitas de suas peças não têm representantes das classes altas

"Muitas destas regiões tinham pouco em comum se não sua adesão ao sistema escravocrata e um sentimento geral de estarem ameaçadas pelo restante do país."

GOETZMANN, William H. Beyond The Revolution - A History of American Thought from Paine to Pragmatism. New York: Basic Books, 2009.

${ }^{147}$ For nature, the endless provider, was of course the moral key to the Southerner's feudal dream.

Tradução:

Porque a natureza, a infinita provedora, era, claro, a chave moral do sonho feudal do sulista.

GOETZMANN, W. p.287 
e latifundiárias do sul. A característica comum à sua galeria de personagens é a marginalidade, que pode ser encontrada tanto nas classes baixas quanto naquelas em decadência. A tensão, contudo, é a mesma: os valores associados ao sul no imaginário da época opostos àqueles mais comumente associados ao sistema capitalista industrial. As situações dramáticas apresentadas em palco carregam em si as tensões estabelecidas entre classes e não os problemas e enfrentamentos de uma classe específica, de forma que, entender o conceito de posição de classe torna-se essencial para a leitura "referencial" das peças. Assim, a idealização de uma pode ser vista como argumento retórico de crítica à outra, sem que nenhuma das classes seja eleita como superior.

Os escravos negros, na sociedade, eram vistos como força de trabalho e ameaça constante. Após a Revolta do Haiti ${ }^{148}$, a possibilidade de um levante escravo entrara para o horizonte de expectativas $^{149}$ das elites sulistas, frente à população majoritariamente composta por escravos. A defesa da escravidão era tanto uma questão essencialmente econômica quanto uma firme e enraizada crença de que os povos negros eram inferiores ${ }^{150}$. Um argumento que usavam em sua defesa era a

\footnotetext{
${ }^{148}$ A importância da revolução do Haiti é inestimável, suas consequências nos Estados escravistas, em relação ao horizonte de expectativa de suas elites, foram tremendas. Reações a ela podem ser encontradas nitidamente na história brasileira e americana.
}

In August 1791, after two years of the French Revolution and its repercussions in San Domingo, the slaves revolted. The struggle lasted for 12 years. The slaves defeated in turn the local whites and the soldiers of the French monarchy, a Spanish invasion, a British expedition of some 60,000 men, and a French expedition of similar size under Bonaparte's brother in law. The defeat of Bonaparte's expedition in 1803 resulted in the establishment of the Negro state of Haiti which lasted to this day.

Tradução:

Em agosto de 1791, dois anos depois da Revolução Francesa e suas repercussões em São Domingo, os escravos se revoltaram. A batalha durou 12 anos. Os escravos venceram os brancos locais e os soldados da monarquia francesa, uma invasão espanhola, uma expedição britânica de por volta de 60.000 homens e uma expedição francesa, de tamanho similar, conduzido pelo cunhado de Bonaparte. A derrota da expedição de Bonaparte, em 1803, resultou no estabelecimento do Estado negro do Haiti, que permanece até hoje."

JAMES, C.L.R. The Black Jacobins - Toussanit L'Ouverture and the San Domingo Revolution. 2a Edição. New York: Vintage Books, 1963.p.XIX

${ }^{149}$ A história concreta amadurece em meio a determinadas experiências e determinadas expectativas.

KOSSELECK, R. "Espaço de experiência" e "horizonte de expectativa": duas categorias históricas. In.: Futuro Passado contribuição à semântica dos tempos históricos. Rio de Janeiro: contraponto, 2006.p.309.

\footnotetext{
${ }^{150}$ Muitos estudiosos do sul, em tentativa de provarem ao mundo que a escravidão não deveria ser combatida, dedicaram-se a defesas científicas, deterministas, como a pesquisa de Dr. Josiah C. Nott e de George R. Gliddon sobre as diferenças entre os tamanhos das caixas craniais, para provar a inferioridade dos negros. Os resultados, claramente, foram bastante insignificantes.

Alguns estudiosos supõem que o Calvinismo também tenha contribuído com o argumento de que a ideia de predestinação poderia ser apropriada de forma conveniente à defesa da escravidão. Goetzmann afirma "Paradoxically a religion born of revolution and desire for freedom could be used as the basis for the defense of slavery."
} 
crítica à selvageria do capitalismo e das fábricas ao norte que, também, escravizavam o homem (branco, não só negro), por meio da escravidão dos salários - wage slavery. ${ }^{151}$ Isso também se mantém no imaginário do sul dos Estados Unidos até os tempos modernos, sendo tematizado constantemente em peças de Tennessee, como algo que teria massacrado o espírito naturalmente delicado e mais harmonioso dos homens do sul. A peça "The strangest kind of romance”, por exemplo, é inteiramente dedicada a esse tema. A hostilidade em relação às maneiras de exploração do trabalho difundidas no norte também se desenvolveu na forma de uma diferenciação na própria motivação que levaria os homens ao trabalho, como se vê na peça "The last of my solid gold watches $^{152,}$, em que o trabalho honesto e dedicado de um vendedor ambulante de sapatos era revestido de valores de honra bastante abstratos, que teriam se perdido na nova cultura que ali chegara. O olhar crítico em relação às formas capitalistas de exploração do trabalho que o sul desenvolve é muito similar àquele desenvolvido entre a intelligentsia russa durante o século XIX, especialmente por pensadores como Herzen e Bielínski.

Um fato curioso é que o discurso sulino contra as formas de vida e produção do norte era construído por meio de dados que, na Europa, compuseram as críticas socialistas, inclusive, as de Karl Marx ${ }^{153}$. Não por acaso, tais temas e críticas ressurgem na literatura americana dos anos 1930 e 1940, que impelida pelo colapso econômico gerado pela crise de 1929, se viu levada a um exercício de autorreflexão e revisão daquilo que consideravam definir o sonho americano (caracterizado, em grande medida, pela ideologia provinda do norte e de seu modelo econômico). Questionando o velho sonho e suas promessas de sucesso num mundo liberal, alguns voltaram seus olhos ao passado e seus

Tradução:

Paradoxalmente, uma religião nascida da revolução e do desejo pela liberdade poderia ser usada como base para a defesa da escravidão.

GOETZMANN, 2009. p. 301

${ }^{151} \mathrm{O}$ argumento aparece com força nos escritos de John Calhoun. "In addition, he pointed to clear signs of discontent with 'wage slavery' and the factory capitalist system, which were signified by the frequency of agrarian handicraft oriented utopian experiments (...)."

Tradução:

"Além disso, ele aponta para claros sinais de descontentamento com a 'escravidão salarial' e o sistema capitalista de fábricas, que eram significantes perante a frequência de experimentos utópicos baseados em manufaturas agrárias." GOETZMANN, 2009. p. 301

${ }^{152}$ WILLIAMS, T. 1949.

${ }^{153}$ GOETZMANN, W. p. 297. 
valores perdidos, por meio dos quais, acreditavam, o homem talvez pudesse ter tido um futuro melhor. Claro está que a nostalgia de tal visão do passado visava enfatizar exatamente as qualidades positivas idealizadas, que aparecem em personagens como Blanche, a delicadeza de espírito, o amor às arte, uma sensibilidade maior em relação ao humano e a honra, sem deter-se em demasia sobre as injustiças sociais que ali também eram perpetradas.

De certa forma, torna-se claro um posicionamento crítico do escritor tanto perante as referências demasiadamente idealizadas a esse passado mitológico associado às camadas altas do sul dos Estados Unidos quanto pelo uso retórico desse mesmo passado, perante o novo pensamento em ascensão identificado comumente à cultura do norte do país.

Um enfoque sobre a história da Rússia revela que sua economia, na primeira metade do século XIX, passou por diversas transformações conjunturais. Após a conquista dos territórios ao sul, a produção agrícola cresce consideravelmente, especialmente o plantio e venda de grãos. O aumento das possibilidades de comércio, aliado ao crescimento demográfico, acabou elevando o preço das terras, concentrando ainda mais a renda da população. Por outro lado, apesar das circunstâncias otimistas, o crescimento era limitado pela estrutura ainda arcaica das instituições do país.

Após as Grandes Reformas realizadas durante o reinado de Alexandre II, a sociedade e a economia russas passaram por mudanças substanciais que transformariam toda a estrutura social dali para frente. A libertação dos servos, em 1861, talvez seja a mais significativa dessas reformas, ao lado da criação do zemstvo, um sistema de autorregulamentação do campo e, depois, das cidades, e as diversas reformas militares, judiciais e penais.

As reformas "modernizantes", não obstante as muitas tentativas de manter a ligação com a nobreza sempre aberta e satisfatória, impulsionaram o processo de decadência dessa classe, sem que ela perdesse ainda seu papel dominante, e facilitaram o crescimento da classe média ligada à indústria. A classe nobre dos grandes proprietários rurais, já endividada desde antes da libertação dos servos, foi incapaz de reverter em capital o dinheiro resultante da indenização recebida do Estado, não efetivando as modificações necessárias em suas estruturas. Além disso, os dados estatísticos levantados provam que, da metade do século até 1890, o tamanho médio de suas propriedades havia 
sido reduzido em 40\%, e o total de terras que possuíam caído em 1/3.

Deprived of serf labor and forced to adjust to more intense competition and other harsh realities of the changing world, members of the gentry had little in their education, outlook and character to make them successful capitalist farmers. A considerable number of landlords, in fact, prefered to live in Paris or Nice, spending whatever they had left, rather than face the new conditions in Russia. 154

A citação acima, quando acrescida das questões camponesas que assolavam a nação, parece se referir à fábula "social” subjacente à peça O Jardim das Cerejeiras, como já visto no capítulo anterior. As muitas transformações que marcaram esse período histórico são um dos cernes da escrita tchekhoviana, de onde retira as possibilidades de suas situações dramáticas.

A característica predominantemente agrária do país levava muitos a imaginarem que a Rússia não entraria na ordem capitalista, que ganhava cada vez mais força no Ocidente. No entanto, as reformas de Alexandre haviam desencadeado um processo de industrialização que, até a década de 1890, atingiria índices espantosos de crescimento (8\% ao ano e, depois da crise de 1900, 6\%). Apoiados pelo Estado e junto às muitas medidas protecionistas impostas pelo Ministério de Finanças, a indústria russa conseguiu se desenvolver de maneira espantosamente rápida, contando com oito regiões industriais especializadas até o final do século.

Como consequência, o país aumentou sua população urbana, desenvolvendo um mercado de mão de obra industrial ainda pouco qualificado por ser composto majoritariamente por ex-servos. A população campesina, recém liberta, sentiu o impacto das reformas de Alexandre, que transformavam a estrutura da nação. Se, por uma lado, as reformas tinham criado uma oportunidade de crescimento econômico - a classe de industriais e profissionais liberais que se desenvolveu incorporava desde nobres até ex-servos, além de muito estrangeiros -, por outro, haviam deixado a classe camponesa totalmente sem mecanismos de absorção social, muito similar ao que ocorrera nos Estados Unidos e no Brasil com os escravos. A impossibilidade da situação na qual se encontravam, agravada pelos esmagadores impostos que lhes eram cobrados como tentativa para angariar capital para o sustento de indústrias ainda pouco competitivas no mercado internacional, elevou ainda mais as tensões sociais.

154 RIASANOVSKY, Nicholas V. \& STEINBERG, Mark D. A History of Russia. New York: Oxford University Press, 2005. p.398.

Notar as semelhanças entre a descrição de Riasonovsky e a história particular de Liubov Raniévskaia explorada no capítulo anterior. 
É esse o contexto que pode ser flagrado nas peças de Tchékhov: perante um novo sistema econômico ao qual ainda não havia se adaptado, a nobreza rural se vê obrigada a encontrar novos meios de sustento. A peça As Três Irmãs demonstra isso nos papeis de Olga e Irina, que se empregam para aliviar seus crescentes problemas financeiros, mesmo que justifiquem que o fazem para aliviar o tédio que sentem. A preocupação que Olga demonstra em relação às altas perdas que Andrei tem em jogos e o fato de TTchebutikin, seu inquilino, não estar pagando o aluguel, são fatos que levam a considerar que algo além do enfado as motivava. Em O Jardim das Cerejeiras, porém, fica ainda mais evidente a situação dessa parcela da elite rural, quando na peça, além de Raniévskaia admitir não possuir mais dinheiro algum, sua propriedade é leiloada como forma de quitar suas dívidas.

Nas peças, como já mencionado anteriormente, é representada também a figura do burguês, classe que se encontrava em ascendência. Lopákhin, em O Jardim das Cerejeiras, e Natacha, em As Três Irmãs, aparecem como espécies de antagonistas sociais à elite rural, pois serão eles os herdeiros daquele mundo que se esfacela. A burguesia é o futuro para o qual olham com desdém e preocupação. Tchékhov, como Tennessee o havia feito, não vilaniza aqueles que ascendem, mas coloca em questão seus valores materialistas e vulgares. No entanto, também como Tennessee, ele não esconde as fissuras que existem na estrutura de valores nobres, sua hipocrisia, indecisão e inépcia.

A hipocrisia da elite aparece nas duas peças de Tchékhov de maneira muito clara quando se refere a uma mesma questão: o lugar reservado aos servos. Olga, em As Três Irmãs, mostra-se alarmada perante a insistência de Natacha quanto à expulsão de Anfisa, a velha babá; ela teme pelo futuro da senhora que seria "devolvida" ao campo e entende o ato de Natacha como extremamente desumano, de maneira que não sabe sequer reagir. No entanto, apesar de manter a babá consigo e no final ir morar com ela na escola onde leciona, não questiona a situação dos demais camponeses, nem mesmo a injustiça que existe no próprio fato de uma senhora, após 30 anos de serviço, não possuir nenhum resguardo, nenhuma segurança oficial, se não a caridade daqueles que a empregavam.

ANFISA (Exausta): Oliuchka, querida... não me enxote!... Não me enxote!

OLGA: Ora, não diga bobagens, babá, ninguém vai enxotá-la.

ANFISA (Deita a cabeça no peito de Olga): Minha querida, meu tesouro, eu trabalho, eu me esforço. Quando me faltarem forças, então me dirão: "Vá com Deus!"... Mas aonde eu posso ir? Com oitenta anos... Vou fazer oitenta e dois... 
OLGA: Sente-se um pouco, babá. Está cansada, pobrezinha... (Faz com que ela se sente.) Descanse pobrezinha, ai como está pálida!

Também Macha e Irina, ambas integrantes da elite, se irritam em diversos momentos da peça com Anfisa e a destratam, como Andrei o faz com o velho e surdo Ferapont. Em O Jardim das Cerejeiras, o descaso para com os servos é tamanho que, uma vez vendido o jardim, a casa é inteiramente fechada, e o velho mordomo, Firs, é esquecido lá dentro. Ademais, em muitas de suas falas, Tchékhov aborda diretamente a questão da abolição.

FIRS: Foi assim mesmo antes da desgraça... a coruja piou. E o samovar assobiou e tossiu o tempo todo.

GAIÉV: Que desgraça?

FIRS: A abolição. ${ }^{155}$

Em 1861, com a abolição da servidão, os proprietários ruraisrecebem um golpe fatal. A nobreza provincial, já em decadência desde o início do século, vê-se completamente endividada e, agora, privada de sua mão de obra. De certa forma, a maneira na qual Tchékhov representa a situação dos ex-servos coloca em questão a eficiência das medidas tomadas na ocasião da abolição, explicitando, por exemplo, com Anfisa e Firs, o fato dessa liberdade não lhes garantir qualquer espaço dentro da nova sociedade, especialmente para os mais velhos. Como aparato de sustento da estrutura da elite agrária, o lento desaparecimento do espaço reservado à nobreza implica também em consequências para os servos: para o bem, é claro, por sua libertação, mas também para o mal, pois a estrutura social encontra-se disposta a absorver somente as parcelas úteis do contingente recém-

${ }^{155}$ TCHÉKHOV, A.P. 2014. p.47.

As opiniões de Firs, pelo caráter cômico que têm, parecem servir como forma de ridicularizar a oposição à abolição, como pode ser visto no excerto a seguir:

FIRS: É porque eu já estou vivo há muito tempo. Quando eles quiseram me casar, o seu pai nem era nascido. (Ri.) E quando veio a abolição eu já era primeiro criado de quarto. Mas é claro que eu fui contra, não aceitei a abolição: fiquei com o meu amo. E com a minha am. Eu me lembro de todo mundo festejando, todo mundo contente. Mas contente por quê? Ninguém sabia.

LOPÁKHIN: A vida era muito melhor, naquele tempo. Não faltava chicote para ninguém.

FIRS (Sem ouvir): Pois é! Os mujiques conheciam seu lugar e os senhores conheciam muito bem o deles. Hoje em dia está tudo tão confuso que a gente não sabe mais quem é ninguém.

TCHÉKHOV, A.P. 2014. p.43. 
liberto de homens.

Um dos casos de absorção está na figura de Lopákhin, filho de servos que trabalhavam na propriedade da qual, no final da peça, será proprietário. Ele representa uma pequena parcela dos servos que, durante seus trabalhos e com as mudanças econômicas que haviam ocorrido na Rússia, conseguiram juntar dinheiro o suficiente para comprar a liberdade e, assim, o futuro. É muito interessante notar como Tchékhov não simplifica sua posição, colocando na personagem sentimentos de conquista, mas também certos sentimentos de lealdade à família, quando tenta ajudá-los a não perder a propriedade. Lopákhin tenta evidenciar maneiras como Raniévskaia poderia tornar a propriedade lucrativa se dividisse o terreno, construindo casas e as alugando. A única resposta que recebe chega na forma de desdém e descrédito.

É interessante notar que um dos principais óbices à sobrevivência da nobreza dentro da economia de mercado é a sua mentalidade. O nobre provincial russo não se importa com a produção da fazenda, pois não é o lucro o importante, seu status deriva de sua mansão, de suas maneiras, de suas "almas" (Gógol explorou essa faceta da nobreza provincial com maestria em Almas Mortas). "Few appeared to understand that income was not profit"156, o pouco que conseguiam arrecadar em suas fazendas, inicialmente, não se transformava em capital (não era reinvestido), no geral, era gasto com produtos luxuosos da Europa e, já na época de sua decadência, era quase totalmente absorvido pelos pagamentos da hipoteca de suas terras. Essa vaidade com a imagem, tipicamente aristocrática, permanecerá na sociedade russa até a Revolução de 1917 e será ricamente explorada por diversos artistas do período, dado o potencial paradoxal que possuía - a nobreza decadente e sua etiqueta serão constantemente confrontadas com o ex-servo, aburguesado, endinheirado e filisteu. Chama a atenção também que, tendo perdido um dos pilares de seu status como nobres, eles tentarão se agarrar ao que lhes resta - costumes, cultura, etiqueta -, levando os traços ao seu limite, na intenção de explicitar suas diferenças em relação aos novos ricos que ascendiam.

Os servos recém-libertos, aos poucos, se inserem no mercado de trabalho como assalariados, sendo absorvidos tanto nas fábricas que haviam surgido no período quanto no campo, onde alguns conseguiram ascender, chegando a comprar as terras de nobres decaídos. A geração de seus filhos, no

\footnotetext{
${ }^{156}$ FIGES, Orlando. A People's Tragedy - The Russian Revolution. London: Penguin Books, 1996.

Tradução:

Poucos pareciam entender que renda não era lucro.
} 
geral, formou a camada média e o proletariado da população das cidades e se distribuiu pela província como camponeses e pequenos proprietários de terra ${ }^{157}$.

Como se vê, o século XVIII foi um século de transformações para a Europa e para o mundo. A partir da Revolução Industrial inglesa, a mentalidade mercantilista foi lentamente substituída pelo liberalismo, e o capitalismo comercial foi se transmutando em capitalismo industrial. Essa mudança gera inúmeras consequências para o mundo, e as relações econômicas e comerciais que se estabelecem entre os Estados serão ditadas por esse novo paradigma de divisão internacional do trabalho, exigindo que cada nação assuma um papel específico. Aos poucos, o mundo inteiro se divide entre fornecedores de produtos primários e produtores industriais, e, assim, muitos países passarão os próximos dois séculos em uma luta pela correção de sua balança comercial.

A chegada da segunda fase da Revolução Industrial - a primeira se dera por meio da indústria têxtil, cujos efeitos foram amplamente sentidos no sul dos Estados Unidos e no sul da Rússia, ambos fornecedores de matéria-prima - cria as condições necessárias para a expansão do mercado de commodities, tanto pela construção de ferrovias, que facilitam o fornecimento, quanto pelo desenvolvimento da navegação marítima (a vapor). No século XIX, a dinâmica do sistema se acelera ainda mais e, então, resta se adaptar ou afundar. ${ }^{158}$

Fato fundamental para a compreensão desses acontecimentos é que trata-se de um processo. A transformação é lenta e desigual. Forma-se vagarosamente "Um sistema articulado de relações de produção capitalista, semicapitalista e pré-capitalista ligadas umas às outras por relações capitalistas

\footnotetext{
${ }^{157}$ FIGES, O. 1996.

${ }^{158}$ La Harpe, tutor do tzar Alexandre I, pressentindo os ares de mudança no mundo, afirmara a seu pupilo: "We are passengers on the boat of Revolution. We must either reach the shore or sink."

Tradução:
}

Somos passageiros no barco da revolução. Nós temos que ou alcançar terra ou afundar.

BILLINGTON, J. The Icon and The Axe. New York: Vintage Books, 1970. p.363. 
de troca e dominadas pelo mercado capitalista mundial"159.

A compreensão da diferença entre o modo capitalista de produção e o mercado capitalista mundial $^{160}$ é indispensável. Estão contidas no descompasso que ela representa as realidades das quais tratou-se até o momento. Tanto a Rússia quanto o sul dos Estados Unidos tiveram de lidar com esse caráter paradoxal de sua economia. Ambas as regiões eram ainda sustentadas pela mão de obra escrava / servil, que não só se apresentaria como obstáculo à formação de um mercado consumidor forte - por seu baixo poder de compra -, como também seria responsável pela baixa produtividade pois o trabalho compulsório, além de dificultar a opção pela mecanização, é pouco eficiente; no geral, pela falta de iniciativa e incentivo aos trabalhadores.

Muito embora tenha havido esforço rumo à modernização por parte de ambos os países, o quadro no qual se inseriam à época não pode ser considerado verdadeiramente capitalista. Encaixam-se no que Wolf chama de movimento de commodities:

\begin{abstract}
O movimento das commodities em âmbito universal gerou preços e dinheiro que fazia dinheiro, mas ainda sem subordinar os meios de produção e a força de trabalho ao capital. Somente a conversão dos meios de produção e da força de trabalho a fatores a serem adquiridos e vendidos no mercado criou o mercado 'autorregulador' dos economistas, que tudo abarcava.161
\end{abstract}

A contradição entre os sistemas de funcionamento regional e os sistemas mundiais é sentida com bastante força pelas elites, primeiro como estímulo à intensificação do comércio, depois como prova do atraso de suas estruturas, que fracassam em atingir o nível necessário de competitividade. As circunstâncias são agravadas, ainda, por guerras (Guerra de Secessão e Guerra da Crimeia) e pela abolição da escravidão e da servidão (1861, na Rússia e nos Estados Unidos). Este é o golpe fatal sobre suas estruturas anacrônicas. A adaptação, que já fora difícil sem gastos com mão de obra, torna-

\footnotetext{
159 O que Mandel denomina de capitalista refere-se ao capitalismo comercial, termo adotado por outros teóricos na diferenciação do capitalismo. Semi e pré-capitalista referem-se ao que se conhece por capitalismo comercial e os métodos de produção anteriores, respectivamente.

WOLF, Eric R. A Europa e os Povos Sem História. São Paulo: Edusp, 2009.

${ }^{160}$ Wolf aponta que a mera inserção do país no mercado capitalista mundial "Não transforma todos os povos do mundo em produtores industriais de valores excedentes."

WOLF, E.2009. p.379

${ }^{161}$ WOLF, E. 2009. p.381.
} 
se sensivelmente pior quando as elites são obrigadas a pagar por sua mão de obra, especialmente por não haver ainda um mercado de trabalho estabelecido.

Nos dois países, houve especialização regional. Coincidentemente, no norte se desenvolveu o setor industrial e, no sul, por razões climáticas, o agrário. Isso significa que em ambos havia um sistema de trocas regionais estabelecido e que a convivência com o modo capitalista de produção era próxima e intensa. É possível levantar a hipótese de que essa convivência tenha contribuído para a formação de um sentimento de aversão à formatação capitalista, pois identificavam nele a pressão que os obrigava à mudança. Nos Estados Unidos, isso é visível na histórica rivalidade entre Yankees e Cavaliers materializada na Guerra de Secessão e que pode, em última análise, ser entendida como um combate entre ideologias econômicas e culturas diversas. Na Rússia, a rivalidade não se desenvolveu com caráter tão distintamente regional (mesmo havendo certa especialização no norte e no sul), mas se concentrou na oposição entre o defensores do modus operandi das áreas urbanas e os das pequenas províncias agrárias. Muitas das críticas eslavófilas ${ }^{162}$, por exemplo, colocavam-se contra o modelo de São Petersburgo, uma grande capital cosmopolita e industrializada já subjugada pelo modelo econômico ocidental.

É possível, então, vislumbrar a posição de classe que as elites agrárias ocupavam dentro de suas respectivas estruturas. Confrontadas, por um lado, pelas elites industriais e capitalistas, às quais o mercado mundial garantia apoio, e, por outro, pela ascensão de uma camada média "aburguesada", que ameaçava assumir a liderança econômica, pouco havia para que simpatizassem com o capitalismo. O fato da pressão capitalista ser interna (e não externa, como foi o caso brasileiro) gerou consequências também bastante similares para essas elites. A solução que encontraram foi se

162 "Since industrial capitalism scarcely existed in Russia before mid-century the nascent intelligentsia of the 1840's knew it not through direct experience but from reports from the West and visits abroad. As outsiders to the experience of capitalism, the early intelligentsia took less interest in it as an economic system than as a social formation. The disruptions to traditional social arrangements and occupations caused by early accumulative capitalism, the hardships of the wage system, the excesses of wealth enjoyed by the new bourgeoisie and the culture that wealth fostered made a painful impression on the Russian intelligentsia."

Tradução:

Como o capitalismo industrial existia escassamente na Rússia antes de meados do século, a intelligentsia nascente da década de 1840 não o conhecia por experiência direta, mas através de relatos do Ocidente e visitas ao estrangeiro. Como forasteiros à experiência do capitalismo, a intelligentsia inicial se interessou por ele menos como um sistema econômico do que como uma formação social. $\mathrm{O}$ desmembramento ocasionado pelo capitalismo acumulativo inicial à tradicional organização social e suas ocupações, as dificuldades causadas pelo sistema assalariado, os excessos de riqueza aproveitados pela nova burguesia e a cultura que essa riqueza nutria causaram uma impressão dolorosa sobre a intelligentsia russa.

DOWLER, W. The intelligentsia and capitalism. In. LEATHERBARROW, William, e Derek OFFORD, . A History of

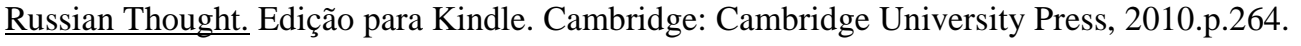


voltarem para dentro, buscando elementos que lhes fossem exclusivos para exaltarem, como a posição de fronteira que ocupavam (entre o mundo civilizado da aristocracia e o selvagem da natureza e dos camponeses ou mesmo o mundo filisteu e rude da burguesia).

Ao mesmo tempo em que decaíam, essas elites precisavam manter clara e viva a distinção entre elas, aristocratas (fictícios ou não) e as novas camadas ascendentes da sociedade. Se anteriormente isto era feito por meio da supremacia econômica, agora falidos, era necessário encontrar uma nova base de argumentação: o orgulho e a ostentação de sua classe social (não mais econômica). Seria por meio da insistência sobre a projeção de uma imagem de nobreza e aristocracia, mesmo sem fundamentos para corroborá-la, que tentariam provar-se de um mundo diferente.

Adotando o conceito de peso funcional do sociólogo Pierre Bourdieu, torna-se mais fácil entender como a trajetória de queda dessas elites reforçava sua perda de espaço dentro das sociedades, e, igualmente, como as burguesias em ascensão passavam a ampliar seus territórios:

Seria preciso mostrar igualmente como as características das diferentes classes sociais dependem não apenas de sua posição diferencial na estrutura social, mas também de seu peso funcional nesta estrutura, peso proporcional à contribuição dessas classes para a constituição desta estrutura, e que não se resume apenas à sua importância numérica. ${ }^{163}$

Nos contextos históricos abordados, o peso funcional das elites também está mudando, configurando a direção vetorial de seus processos (ascendente ou descendente).

Nas configurações espaciais de Um Bonde Chamado Desejo e de As três Irmãs, é possível encontrar a representação metonímica dos movimentos vetoriais de suas elites. Como alegorias do espaço histórico, as peças problematizam as disputas entre modelos sociais dominantes. As personagens, cada qual representativa de um paradigma sociocultural, absorvem e condensam as diversas tensões, manifestando-as através de seus pontos de vista.

As irmãs Olga, Macha e Irina representam a classe social da qual provêm, exacerbando muitas de suas características para tornar essa identificação ainda mais clara, como também é o caso de Blanche DuBois, que a todo momento menciona sua ascendência, adequando seus gestos, sua fala e sua vestimenta àquilo que lhe era designado como integrante da elite. $\mathrm{O}$ mesmo ocorre com os

${ }^{163}$ BOURDIEU, P. 1974.p.12. 
representantes do estrato social antagônico, do lado deles também é sentido o conflito; a pressão funciona para ambos os lados. Se no início da peça de Tchékhov, Natacha sente-se acuada e tímida frente à sua apresentação para as pessoas da alta sociedade, ela será vista tentando mimetizar o comportamento daqueles que a julgavam, como nas diversas vezes em que fala em francês - sempre errado, garantindo certo humor às cenas -, e, no final, reproduzirá o mesmo comportamento das irmãs no ato de sua apresentação. Assim, mostra-se que a tensão é sentida pela classe ascendente e é confrontada sem recuo, afinal, é Natacha quem irá de fato mandar na casa ao término da peça.

(Entra Natacha Ivanovna; está trajando um vestido cor-de-rosa com cinto verde.)

NATACHA: Ah, já estão sentados à mesa. Cheguei atrasada. (de relance olha-se no espelho e ajeita o cabelo.) O penteado parece que não está mal... (Nota a presença de Irina) Irina Serguêievna, querida, meus parabéns. (Beija-a forte e longamente.) Ai, estão com tantas visitas, fico embaraçada... Bom dia, Barão.

OLGA (Entra na sala.) Ah, chegou Natália Ivanovna também. Seja bem-vinda, querida. (Trocam beijos.)

NATACHA: A reunião está muito concorrida hoje, fico acanhada...

OLGA: Ora, todo mundo aqui é de casa. (A meia-voz, assustada). Meu Deus, está usando cinto verde? Querida, isso é simplesmente impossível!

NATACHA: Por acaso significa algo ruim?

OLGA: Não, não, apenas vai terrivelmente mal. Como se...

NATACHA (Chorosa.): É mesmo? Mas quase nem é verde, de tão pálido. (Segue Olga à sala de jantar. Todos tomam assento em torno da mesa; não restou ninguém na sala)

(...)

TTCHEBUTIKIN: Eu sou um velho pecador, mas por que razão Natália Ivanovna corou, isso é o que eu não entendo. (Risadas estrepitosas. Natacha sai aos atropelos da sala de jantar, parando na sala. Andrei a segue.)

ANDREI: Peço-lhe penhoradamente, não lhes dê atenção! Espere, pare, por favor.

NATACHA: Que vergonha... Não sei o que se passa comigo. E eles ficam rindo de mim. Não devia ter saído da mesa desse jeito; foi uma falta de educação, eu sei, mas não aguento. (Esconde o rosto na palma da mão.)

ANDREI: Querida, peço-lhe, suplico-lhe que não se aborreça! Asseguro-lhe que eles só estavam brincando, são bem-intencionados. Minha querida, minha cara, todos são pessoas boas e decentes. Amam muito a mim e também à senhora. Venha até aqui na janela, aqui eles 
não nos vêem... (Olha ao redor.)

NATACHA: Não estou acostumada a essas reuniões sociais. ${ }^{164}$

NATACHA: Então amanhã estarei sozinha aqui (Suspira). Antes de mais nada mandarei cortar os abetos da alameda, depois esse álamo aqui... à noite são tão feios... (A Irina.) Querida, esse cinto não lhe fica bem... É simplesmente de mau gosto. Devia usar algo mais claro. E aqui plantarei flores por toda partem flores bonitas e perfumadas. (Em tom severo.) Quem deixou esse garfo aqui no banco... pergunto eu? (Entra na casa; à criada.) $\mathrm{O}$ que faz o garfo no banco? (Grita.) Cale a boca! ${ }^{165}$

Stanley Kowalski também sofre os efeitos da pressão imposta por Blanche, muitas das investidas que tem contra a personagem são reações à sua insistência sobre as características de classe que a separam dele. As inúmeras referências a livros, a poemas e à riqueza das artes em geral são uma forma dela se provar superior àquilo que Stanley representa.

STANLEY: What do you teach, Blanche?

BLANCHE: English.

STANLEY: I never was a very good English student. How long you in for, Blanche?

BLANCHE:I - don’t know yet.

STANLEY: You going to shack up here?

BLANCHE: I thought I would if it's not inconvenient for you all.

STANLEY: Good.

BLANCHE: travelling wears me out.

STANLEY: Well, take it easy.

(A cat screeches near the window. Blanche springs up.)

BLANCHE: What's that?

${ }^{164}$ TCHÉKHOV, A.P. 2013. p.21-22.

${ }^{165}$ Ibidem.p.63-64. 
STANLEY: Cats... Hey, Stella!

STELLA (Faintly, from the bathroom): Yes, Stanley.

STANLEY: Haven't fallen in, have you? (He grins at Blanche. She tries unsuccessfully to smile back. There is silence.) I'm afraid I'll strike you as being the unrefined type. Stella's spoke of you a good deal. You were married once, weren't you?

(The music of the polka rises up, faint in the distance. $)^{166}$

Stanley, apesar de notar a tensão entre eles, não se julga inferior a Blanche; as qualidades que ela esbanja, para ele, não possuem valor. Para ele, as questões financeiras falam muito mais do que as culturais e artísticas. Buscar o entendimento entre as personagens nas peças parece impossível. Novamente, como se habitassem mundos diferentes, são incapazes de transpor os obstáculos que se interpõe a elas.

STANLEY: I've been on you from the start! Not once did you pull any wool over this boy's eyes! You come in here and sprinkle the place with powder and spray perfume and cover the light-bulb with a paper-lantern, and lo and behold the place has turned into Egypt and you're the Queen of the Nile! Sitting on your throne and swilling down my liquor! I say - Ha! - Ha! Do you hear me? Há- há-há! (He walks into the bedroom.) ${ }^{167}$

${ }^{166}$ WILLIAMS, T. 2000.p. 482.

Tradução:

STANLEY: O que você ensina, Blanche?

BLANCHE: Inglês.

STANLEY: Eu nunca fui um bom aluno de inglês. Quanto tempo vai ficar, Blanche?

BLANCHE: $\mathrm{Eu}$ - ainda não sei.

STANLEY: Vai se amontoar por aqui?

BLANCHE: Pensei que sim, se não for inconveniente para vocês.

STANLEY: Bom.

BLANCHE: Viajar acaba comigo.

STANLEY: Bem, relaxa .

(Um gato grita perto da janela. Blanche levanta-se num pulo.)

BLANCHE: O que é isso?

STANLEY: Gatos... Ei, Stella!

STELLA (Baixinho, do banheiro): Sim, Stanley.

STANLEY:Você não se afogou aí, afogou? (Ele sorri para Blanche. Ela tenta, sem sucesso, sorrir de volta. Silêncio.) Eu sinto que infelizmente devo parecer um tipo pouco refinado para você. Stella me diz bastante coisa a seu respeito. Você foi casada por um tempo, não foi? (The music of the polka rises up, faint in the distance.)

${ }^{167}$ WILLIAMS, T. 2000.p.552. 
Historicamente, sabe-se que a burguesia, uma vez estabelecida como classe dominante, passou a investir em cultura - lembrar dos inúmeros casos do mecenato de grandes industriais para as vanguardas artísticas mundiais, como também, da insistência sobre o próprio modelo do drama burguês. Assim, é curioso notar que ambos os escritores se utilizam do refinamento cultural como elemento de oposição à cultura burguesa. No caso tchekhoviano, mesmo a figura Lopákhin, de $O$ Jardim das Cerejeiras, parece tentar se munir de referências à alta cultura, como se isso fosse uma marca de status associada à posição da elite. Ao mesmo tempo, é interessante notar que as integrantes decaídas da elite encontram refúgio somente em meios culturais, ambas assumem cargos de professora, como se o valor que tivessem estivesse concentrado na cultura que as difere de seus antagonistas.

Cabe dizer que a existência dúbia que essas representantes da elite têm, como se fundamentadas sobre bases feitas de ar, é análoga à posição que na história as elites rurais ocupavam, tanto da Rússia quanto do sul dos Estados Unidos. Esse tema não é particular a Tchékhov e Tennessee e reaparece de forma similar em inúmeros outros escritores, como, por exemplo, em Oblómov, de Ivan Gontcharóv, Palmeiras Selvagens, O Som e a Fúria, entre outros, de William Faulkner. Nessa recorrência, pode ser vislumbrado o desespero que reinava sobre essas classes, ao se agarrarem ao último vestígio de suas vidas passadas, debatendo-se em meio a uma guerra já, há tempo, perdida. Como o cadáver de luvas de Tchékhov ${ }^{168}$, seriam enterradas pela história sem admitirem sua própria queda.

Vê-se, então, que a cultura das elites sulistas americanas e a dos nobres agrários russos se cruzam em ponto bastante específico, historicamente justificado, unindo-se em forte oposição à cultura do dinheiro, considerada vulgar. E é sobre essa semelhança histórica que se ergue esta análise

Tradução:

STANLEY: Eu já estava esperto sobre você desde o início! Não enganou este menino aqui nenhuma vez! Você entra aqui, salpica o lugar com pó e perfume em spray e cobre a lâmpada com a lanterninha de papel e, vejam todos, o lugar se transformou no Egito e estamos todos diante da rainha do Nilo. Sentada no seu trono e tomando o meu goró! Te digo - Há! - Há! Me escutou? Há-há-há! (Ele entra no quarto).

${ }^{168}$ They undressed the corpse, but had no time to take the gloves off; a corpse in gloves.

Tradução:

Eles despiram o cadáver, mas não tiveram tempo de lhe tirar as luvas; um cadáver de luvas Anotação extraída de seu diário, onde anotava pequenas frases que resumiam temas possíveis para suas peças. CHEKHOV, Anton P. The Note-book of Anton Chekhov. Project Gutenberg, 1921. 
dramatúrgica comparativa, pois muito mais do que a admiração, parece ser a visão de uma mesma queda o que aproxima Tennessee e Tchékhov. 


\title{
3. Questões de recepção: \\ Tennessee - Stanislávski - Tchékhov
}

\begin{abstract}
Em grande medida foi a partir dessas duas linhas mestras de trabalho interpretativo [de Lee Strasberg e Stella Adler] que a dramaturgia de Tchékhov viria ser lida, estudada e encenada nos Estados Unidos, e a exercer particular interesse, tanto para atores em formação como para os dramaturgos desejosos de assimilar novas técnicas de caracterização e de sua estrutura.
\end{abstract}

BETTI, Maria Sílvia ${ }^{169}$

É fato conhecido que a turnê americana do Teatro de Arte de Moscou foi de extremo sucesso, e sua influência pode ser sentida desde a cena teatral americana até os filmes de Hollywood. Fato menos conhecido é que foi somente por meio dessa turnê e das mudanças por ela possibilitadas no teatro americano, como o alargamento do conceito de dramático e a introdução de novas técnicas de encenação e atuação, que a escrita dramatúrgica de Tchékhov começou a ser aceita.

Como explicita a citação da epígrafe, o trato dado ao texto dramatúrgico de Tchékhov pelo Teatro de Arte de Moscou, absorvido seu estilo pelas escolas teatrais norte-americanas, consagrou uma forma de leitura de sua obra. O olhar que os diversos diretores e dramaturgos voltaram a este foi, então, profundamente influenciado por tais técnicas. O ambiente no qual Tennessee Williams se desenvolve como dramaturgo é, portanto, um ambiente no qual essa visão de Tchékhov e do fazer teatral estavam em voga.

Para os fins deste trabalho, cabe deter-se em alguns aspectos da recepção americana de ambos, o dramaturgo e a companhia russa, para que se possa investigar como as particularidades dessa leitura se manifestam formalmente na escrita de Tennessee Williams. Uma questão importante, sugerida pela

${ }^{169}$ BETTI, Maria Sílvia.Projeções Tchekhovianas no Teatro Norte-americano. In.: CAVALIERE, Arlete e Vássina, Elena. Teatro Russo - Literatura e Espetáculo. São Paulo: Ateliê Editorial, 2011.p.263 
similaridade entre os processos iniciais de recepção das peças longas de Tchékhov nos Estados Unidos e na Rússia, nos quais seu sucesso parecia depender do desenvolvimento técnico dos processos de atuação e direção, é em que medida a encenação e a dramaturgia interagem e caminham juntas. É também pertinente investigar como o seu desenvolvimento se vincula à lenta ascensão do papel do diretor, ou encenador, na história do teatro dos dois países, o que demonstraria uma mudança efetiva na percepção daquilo que compõe o teatro e sua linguagem.

Retomando o conceito de Lukács, que dita que o verdadeiramente social é a forma, decorre que o gênero dramático na sua acepção moderna, diferentemente dos demais gêneros literários, se comunica em diferentes níveis formais. Assim, a forma do texto dramatúrgico é somente uma de suas camadas, pois, com ela, há ainda a forma da encenação, que considera os muitos elementos materiais de sua existência. As técnicas de atuação, os cenários, a disposição e o movimento de seus elementos no palco, a luz e a trilha sonora, tudo isso também deve ser considerado como parte integrante da forma das peças teatrais e elementos significantes. Da mesma maneira como o conteúdo temático de uma peça se abre à sua forma e estrutura dramatúrgicas, as técnicas de encenação concorrem para que a peça atinja sucesso comunicativo. Encenação e dramaturgia devem provir de uma mesma perspectiva, uma mesma poética cênica.

Se a recepção de Tchékhov se deu por meio de seu formato teatral e não apenas literário, deve-se então considerar o texto em sua inteireza, como peça escrita e produzida.

$* * *$

O que importa verificar é que a peça como tal, quando lida e mesmo recitada, é literatura; mas quando representada, passa a ser teatro. Trata-se de duas artes diferentes, por maior que possa ser a sua interdependência.

ROSENFELD.A.170

Entre a peça escrita e a peça encenada existe uma diferença sensível essencial: os elementos que

${ }^{170}$ ROSENFELD, Anatol; “O Fenômeno Teatral”; Texto/Contexto I; Ed. Perspectiva; São Paulo; 2006; p. 24 
compõem a linguagem do texto escrito são muito diferentes daqueles que compõem a linguagem teatral; de um lado o signo linguístico e, do outro, o gesto tridimensional na encenação, o som, a luz, o movimento e o cenário. Entre umalinguagem e outra, um complexo percurso de preenchimento "com dados sensíveis, audiovisuais, o que o contexto verbal da peça dramática necessariamente deixa na relativa abstração das universálias conceituais" ${ }^{\prime 171}$.

Em cada uma das linguagens, a palavra exerce funções diferentes: “(...) a palavra perde, ontologicamente, a sua função fundante ou constitutiva, cedendo-a ao ator que, metamorfoseado em personagem, torna-se fonte da palavra"172. É interessante notar a relação desse fenômeno com as práticas cênicas instauradas na tradição teatral por Konstantin Stanislávski, que por meio de seu realismo, tanto exterior quanto interior, permitiu ao ator alcançar o grau necessário de autoconhecimento e disciplina para efetuar a metamorfose.

A emancipação da linguagem teatral da palavra para o aproveitamento de seus variados potenciais - possível a partir da ampliação do espectro de elementos significantes durante a encenação - foi uma das inovações técnicas que o trabalho de Stanislávski como diretor trouxe para a história do teatro, viabilizando a produção de dramaturgias não mais criadas em torno somente de diálogos e das ações concretas por eles encadeadas. As formas adotadas pelo drama moderno, cuja ênfase sobrecaía na atmosfera e na situação dramática, em muito se beneficiaram da expansão da linguagem teatral.

A confluência do novo formato dramatúrgico em ascensão e das inovações cênicas stanislavskianas parece ser fruto de uma mesma perspectiva histórica e filosófica. Como visto na análise formal do drama moderno, sua tendência à incorporação de elementos do gênero épico derivam de uma visão ontológica específica (na base também do realismo formal), que parece estar presente também nos novos princípios de encenação. A substituição da ação pela situação, a ampliação do espectro de personagens e a atenção à criação de atmosferas, todos esses expedientes dramatúrgicos encontram respaldo nas novas técnicas defendidas pela companhia: o trabalho em ensemble, a não hierarquização de papéis, a preocupação com a cenografia e a paisagem sonora da peça e o trabalho aprofundado do ator.

A personagem, para Stanislávski, torna-se somente um dos elementos que permitem a transposição da peça em cena. Sua disposição sobre o palco, sua movimentação e, também, o cenário

\footnotetext{
${ }^{171}$ ROSENFELD, A. 2006. p.28.

${ }^{172}$ Ibidem.p.26.
} 
são partes essenciais da composição e da criação da atmosfera - que pressupõe elementos concretos. Se o drama tchekhoviano pode ser considerado um drama de milieu, o tipo de encenação que naturalmente exige é um que possibilite a plena comunicação das características que o compõem, ou seja, um formato de encenação sustentado pelos mesmos pressupostos que sua forma dramatúrgica.

Raymond Williams argumenta que a expansão da linguagem teatral trata da recriação em palco da possibilidade atmosférica (ou stimmung) do romance, ou seja, a tradução dos diversos elementos descritivos existentes nos romances realistas para a realidade sensível do teatro. "Muito da descrição detalhada da atmosfera, do personagem, do olhar, dos gestos, do modo de falar vem de outra forma literária, o romance em que esse tipo de descrição pode ser direta." ${ }^{173}$ Para além do retrato naturalista, os detalhes voltados à criação da atmosfera possuem uma dimensão metafórica que contribui para o desenvolvimento de significados que ultrapassam a dimensão mimética.

Processo similar é defendido por Tennessee em seu conceito de teatro plástico, onde tenta expandir ainda mais essa função significante de elementos físicos, como jogos de iluminação e som, que passam a assumir também um sentido metafórico, como símbolos abstratos do fluxo de pensamento interior das personagens - como ele indica em Um Bonde Chamado Desejo ${ }^{174}$.

Expressionism and all other unconventional techniques in drama have only one valid aim, and that is a closer approach to truth. When a play employs unconventional techniques, it is not, or certainly shouldn't be, trying to escape its responsibilities of dealing with reality, or interpreting experience, but is actually, or should be attempting to find a closer approach, a more penetrating and vivid expression of things as they are. The straight realistic play with its genuine frigidaire and authentic ice-cubes, its characters that speak exactly as the audience

${ }^{173}$ WILLIAMS, R. 2010. p.173

${ }^{174}$ A última cena da peça pode ser vista como parte da proposta de Teatro Plástico de Tennessee, muitos de seus elementos são exagerados, incorporando contornos expressionistas, que recriam no palco aquilo que parece ser a sensação interior de Blanche, como pode ser visto no pequeno excerto que segue:

BLANCHE (Shrilly): Yes! Yes! I forgot something!

(She rushes past him into the bedroom. Lurid reflections appear on the walls in odd, sinuous shapes. The "Varsouviana" is filtered into a weird distortion, accompanied by the cries and noises of the jungle. Blanche seizes the back of a chair as to defend herself.)

Tradução:

BLANCHE (esganiçadamente): Sim! Sim! Eu esqueci uma coisa!

(Ela passa por ele correndo. Reflexos lúridos aparecem nas paredes em formas estranhas e sinuosas. A "Varsouviana" é filtrada para o ambiente numa estranha distorção, acompanhada pelos gritos e barulhos da selva. Blanche se agarra às costas da cadeira como se para se defender.)

WILLIAMS, T. 2000.p.561. 
speaks, corresponds to the academic landscape and has the same virtue of a photographic likeness. (...)

These remarks are not meant as a preface to this particular play. They have to do with a conception of a new, plastic theatre which must take the place of the exhausted theatre of realistic conventions if the theatre is to resume vitality as a part of our culture. ${ }^{175}$

O que sua proposta guarda como base não é um distanciamento da realidade empírica, mas formas representativas que consigam transportá-la ao palco de maneira mais completa, por meio da justa exploração das diferentes variáveis circunstanciais - como elementos do ambiente, das histórias pessoais dos personagens, de suas subjetividades, entre outros - possibilitadas pela expansão da linguagem. Seu apelo à incorporação da imaginação poética parece ter como objetivo ultrapassar os limites da aparência, alcançando os significados subjacentes daquilo que quer representar.

O realismo fotográfico ${ }^{176}$ teatral, criticado por Tennessee Williams, se aproxima de uma visão naturalista, na qual os detalhes "exteriores" (da aparência exterior) teriam prevalência na representação. Em seu lugar, o dramaturgo coloca elementos que não se manifestam na obviedade das aparências. Similar àquilo que o formato do romance permite, suas incursões nos sentimentos, motivações, desejos interiores das personagens, amarras das circunstâncias e peso, o teatro plástico pode ser entendido também como uma expansão do gênero em direção à épica.

"O novo teatro nasce da literatura"177, dissera Meierhold, e, de fato, existe uma ampla relação entre aquilo que se vê no romance e aquilo que ocorre posteriormente nas artes dramáticas. O mesmo

${ }^{175}$ WILLIAMS, T. 2000. p.395.

Tradução:

O expressionismo e todas as demais técnicas não convencionais, no drama, só têm um objetivo válido, que é uma aproximação maior à verdade. Quando uma peça emprega técnicas não convencionais, não é, e certamente não deveria ser, para escapar da responsabilidade de lidar com a realidade ou interpretar a experiência, mas, na verdade, está tentando encontrar uma forma de abordar mais de perto, uma expressão mais penetrante e vívida das coisas como elas são. A peça linearmente realista, com suas geladeiras genuínas e autênticos cubos de gelo, suas personagens que falam exatamente como fala a audiência, corresponde à paisagem acadêmica e tem a mesma virtude que a parecença fotográfica. Estes comentários não são válidos somente como prefácio a esta peça em particular [The Glass Menagerie]. Eles têm a ver com a concepção de um teatro novo, plástico, que deve tomar o lugar do exausto teatro das convenções realistas, se o teatro deve retomar sua vitalidade em nossa cultura.

${ }^{176}$ Cabe ressaltar que a utilização do adjetivo fotográfico parece fazer referência à superficialidade puramente visual que Tennessee enxerga na fotografia.

177 PICON-VALLIN, Béatrice. Texto literário, texto cênico, partitura do espetáculo na prática teatral russa. In.: CAVALIERE, Arlete, e Elena VÁSSINA. Teatro Russo - Literatura e Espetáculo. São Paulo: Atelier Editorial, 2011.p.321 
processo que se desenvolve no drama, como visto no capítulo 2, ocorre no palco, onde elementos épicos passam a ser testados e adaptados para dentro da composição formal do gênero. A atenção aos detalhes no texto tchekhoviano é recriada por Stanislávski, garantindo que a atmosfera poética das peças escritas seja possível em cena.

\begin{abstract}
O que está em questão, numa peça como A Gaivota, é se a atenção aos detalhes pode ser traduzida em termos dramáticos; ou, dizendo de modo mais difícil, se a concepção total da experiência, para a qual os detalhes contribuem, pode ser imaginada e escrita em forma de texto dramático. (...) E não há dúvidas de que essa evolução é inevitável, uma vez que a criação cênica chegou ao ponto de se separar da fala formal e das ações apresentadas que ela pode indicar ou prescrever de modo direto.178
\end{abstract}

É essencial atentar à ideia de total da experiência, por remeter novamente àquela concepção do homem como resultado de forças que lhe são externas. Seria necessário, portanto, ir além do personagem na representação para inseri-lo em um contexto que permita perceber os elementos sociais e seu momento histórico. Mesmo o valor dado às lembranças e à subjetividade interior das personagens carrega a visão de que o presente não é um momento isolado, mas fruto direto do passado que se mantém atuante, limitando suas possibilidades objetivas. No entanto, não se trata da antiga causalidade estrita presente no drama burguês, pois este transpõe os limites das relações intersubjetivas, mostrando a subjetividade individual como relativa à sua exterioridade macro ou, como afirma Williams, sua estrutura metonímica na qual “(...) o colapso pessoal constituía um fato genuinamente social, e um colapso social era vivido e reconhecido na experiência pessoal direta" ${ }^{179}$.

O conceito de tradição desenvolvido por T.S. Eliot ${ }^{180}$ pode levar a cogitar que, após o advento de Stanislávski, a tradição teatral teve que se reestruturar e o passado inteiro teve que ser revisto. Seu

\footnotetext{
${ }^{178}$ WILLIAMS, Raymond. Drama em Cena. Sâo Paulo: Cosac Naify, 2010.p.173

${ }^{179}$ WILLIAMS, Raymond. Tragédia Moderna. 2a Edição. São Paulo: Cosa Naify, 2011.p.183.
}

180 “(...) o sentido histórico implica a percepção, não apenas da caducidade do passado, mas de sua presença. O sentido histórico leva um homem a escrever não somente com a própria geração a que pertence em seus ossos, mas com um sentimento de que toda a literatura européia desde Homero e, nela incluída, toda a literatura de seu próprio país têm uma existência simultânea. (...) Os monumentos existentes formam uma ordem ideal entre si, e está só se modifica pelo aparecimento de uma nova (realmente nova) obra entre eles. (...) para que a ordem persista após a introdução da novidade, a 'totalidade' da ordem existente deve ser, se jamais o foi sequer levemente, alterada: e desse modo as relações, proporções, valores de cada obra de arte rumo ao todo são reajustados; e aí reside a harmonia entre o antigo e o novo." ELIOT, T. S.; Tradição e Talento Individual. In. Ensaios. Rio de Janeiro: Art Editora, 1989. p. 39. 
método possibilitou a expansão do que até então era a linguagem teatral, que passou a contar com outras formas de conduzir a matéria exposta pelo texto teatral.

A expansão daquilo que potencialmente poderia comunicar-se com o expectador está em relação direta com a forma dramatúrgica que Tchékhov adotara. Como vimos, a palavra já não basta como motor propulsor da ação, e é a situação inteira que deve carregar o drama, sendo assim necessário que esta esteja firmemente representada no palco, concentrando a atenção não só nas personagens individuais.

É possível supor que o imenso sucesso do Teatro de Arte de Moscounos palcos americanos - em vista das peças serem produzidas em russo para um público que, em sua maioria, não entendia a língua ${ }^{181}$ - decorra exatamente dessa nova elaboração do drama em cena, como uma totalidade na qual a atmosfera é seu maior elemento significante.

A cena russa, como afirma J. Guinsburg, não mais correspondia "aos reclamos das verdadeiras forças da criatividade artística" ${ }^{182}$ e fazia sentir no ar a necessidade de renovações tanto no repertório quanto nas concepções de interpretação e apresentação.

Ao mesmo tempo, as forças objetivas do mundo que haviam conduzido às quebras formais da dramaturgia animavam as próprias concepções de palco. Como parte de uma mudança substancial nas perspectivas daquilo que era o homem e a realidade, o teatro como texto e como espetáculo passava por mudanças.

Our program was revolutionary: we rebelled against the old way of acting, against affectation, and false pathos, against declamation and bohemian exaggeration, against bad conventionality of production and sets, against the star system which ruined the ensemble, and against the whole spirit of performance and the insignificance of repertory. ${ }^{183}$

\footnotetext{
181 Outra pista que há para isso são as diversas críticas feitas aos espetáculos da época, que prezavam a capacidade de ensemble do diretor e sua companhia, trazendo a atenção não só às conquistas da atuação de cada um de seus atores, mas de sua interação global.

${ }^{182}$ GUINSBURG, Jacó; “Stanislávski e o Teatro de Arte de Moscou”; Ed. Perspectiva; São Paulo; $2006 ;$ p.15.

183 SLONIM, Marc. Russian Theater - from the empire to the Soviets. Cleveland: The World Publishing Company, 1961. P.109
} 
O teatro imperial, que até pouco tempo ainda possuía o monopólio sobre as encenações, se restringia a apresentações de vaudevilles ou melodramas, em geral de origem francesa, e o trabalho do ator (de início, eram servos que "representavam" os papéis) limitava-se à declamação de textos. Não à toa, as mudanças perpetradas por Stanislásvki, com sua visão da obra teatral como um todo orgânico minuciosamente atenta aos detalhes significantes que a compõe, foram vistas como revolucionárias para a época.

Jacó Guinsburg também salienta que as raízes desse processo se encontram no século XVIII, quando a arte teatral se estabeleceu na Rússia. É durante esse período que tem início a produção nacional de textos dramatúrgicos, mas que ainda permaneciam "restritos ao retrato em branco e preto da caractereologia e das paixões do 'vulgar' e são poucos os que fixam traços mais genuínos da vida propriamente russa" ${ }^{184}$. O século XIX, no entanto, produziria circunstâncias que incentivariam uma produção diferente, cujos valores essenciais provinham do realismo e sua proposta de enxergar o mundo como um todo.

Para o teatro, as influências externas que culminaram na formação do Teatro de Arte de Moscou provinham mais especificamente da dramaturgia naturalista que se desenvolvia com os Meinenger, com o Théâtre Libre de Antoine e com Otto Bralim, "em seu empenho para recriar em cena, com precisão por assim dizer científica, a realidade histórica, social e psicológica que a dramaturgia naturalista se propunha a recortar com o bisturi positivista" ${ }^{185}$. Características essas que, à maneira do realismo formal dos romances, estavam em voga de maneira geral nas artes desde o século XVIII. Por meio delas, já se manifestava a concepção da peça como um todo artístico que deveria se submeter "ao poder unificador de alguém que a dirigisse"186.

Aos poucos, a figura do encenador / diretor ganha peso, marcando a separação do teatro como

Tradução:

Nosso programa era revolucionário: nos rebelávamos contra a antiga maneira de atuação, contra a afetação e o pathos falso, contra a declamação e o exagero boêmio, contra o convencionalismo ruim das produções e dos cenários, contra o star system que arruinou o ensemble, e contra todo o espírito da performance e a insignificância do repertório.

${ }^{184}$ ROSENFELD,A. 2006. p.36

185 GUINSBURG, Jacó; "Stanislávski e o Teatro de Arte de Moscou”; Ed. Perspectiva; São Paulo; $2006 ;$ p.15.

${ }^{186}$ GUINSBURG, J. 2006.p.15 
peça escrita e como peça encenada. Concentrava-se nessa figura o processo de mediação entre os gêneros, possibilitando a metamorfose de um formato para o outro, ao explorar os diferentes níveis de significação possíveis dentro da linguagem teatral. De certa forma, no texto tchekhoviano, muitos apontamentos sobre a conduta, o gesto e o silêncio das personagens já estão presentes, porém, sua expansão se dá pelas mãos de Stanislávski, que, além de preencher a peça com detalhes que corroboram o aspecto mimético imediato das personagens em cena, também adiciona elementos cuja referência está na totalidade do drama, como se referentes à situação dramática em si.

O desenvolvimento do método de Stanislávski, como a história comprova, foi essencial para a possibilidade de encenação das peças tchekhovianas. A mudança do centro gravitacional da peça, do ator para a atmosfera e do texto para o todo forneceram à forma de seus dramas substrato ideal para o seu total desenvolvimento.

Isso não quer dizer que um surgiu em função do outro, mas que as circunstâncias culturais e históricas, como já apontado em diversos momentos aqui, atuaram de maneira similar sobre a evolução da dramaturgia e da linguagem teatral concreta.

For better or for worse, Chekhov's plays were written at a time when the stage director was becoming a paramount factor in the theatre. In the wake of Ibsen, the dramatist's message took precedence over the actor's virtuosity. In the wake of Wagner, the unified 'vision' of a single maker took precedence over the individual contributions of performer, musician and designer, The technical innovations of the modern stage, including electric lighting and mises-en-scène intent on reproducing 'real life", required expert handling to blend and harmonize the various elements, Chekhov's development as a playwright from 1988 to 1904 coincides with this move from a stage governed by histrionic and spectacular display to one in which the ensemble effect and creation of "mood" reigned supreme. ${ }^{187}$

${ }^{187}$ SENELICK, L. The Complete Plays of Anton Chekhov. New York: Norton \& Company, 2006.p.3.

Tradução:

Para o bem ou para o mal, as peças de Tchékhov foram escritas num momento no qual o diretor de palco estava se tornando um fator supremo no teatro. No surgimento de Ibsen, a mensagem do dramaturgo preponderava sobre o virtuosismo do ator. No surgimento de Wagner, a "visão" unificada de um único criador preponderava sobre as contribuições individuais do performer, do músico e do designer. As inovações tecnológicas do palco moderno, incluindo a luz elétrica e a intenção dos mises-em-scènes em reproduzir a "vida real", exigiam tratamento especializado para unir e harmonizar os variados elementos. O desenvolvimento de Tchékhov como dramaturgo, de 1988 a 1904, coincide com essa mudança do palco governado pela apresentação histriônica e espetacular para uma na qual o efeito de ensemble e a criação da "atmosfera" reinavam supremos. 
Essa foi uma das grandes inovações da visão teatral de Stanislávski, uma mudança de foco, da imposição do papel do ator sobre a peça, na criação de um conjunto orgânico em que não há hierarquia, onde tudo se complementa de modo a transformar o palco em um universo completo e com vida própria.

Tais características alcançarão sua maturidade com a formação do Teatro de Arte de Moscou, em 1898, ao lado de Niemiróvitch-Dântchenko. Apesar do desenvolvimento da companhia teatral ter passado por diferentes fases, desde a encenação de dramas históricos até peças simbolistas, é com a dramaturgia de Tchékhov que Stanislávski atingirá o sucesso que lhe garantiria sucesso internacional.

O fracasso de A Gaivota no Teatro Aleksandrínski, em 1896, oferece uma pista para entender a futura simbiose que ocorreria com essa peça e o TAM. Os atores, como recorda Slonim ${ }^{188}$, tinham preparado superficialmente os papéis de seus personagens, considerando tão somente aqueles que pareciam ser os centrais para a peça - o que se faz pensar que tinham em mente o modelo do drama burguês e sua estrutura de personagens, ação e conflito -, aos demais personagens não fora despendida nenhuma atenção, como também pouco havia sido feito para garantir a unidade atmosférica da peça.

Quando, em 1989, o TAM assume a produção da peça, partem do pressuposto de que deveria haver consistência entre o tom (ou stimmung) e o design da peça, além de todos os personagens terem o mesmo trato aprofundado. O caráter orgânico das encenações, baseado na visão de veracidade que pautava a leitura stanislasvkiana provou-se essencial. Até mesmo a atenção que Tchékhov dava aos detalhes significantes encontrou respaldo na fórmula do TAM, como relata Slonim ${ }^{189}$.

Stanislávski e Dântchenko haviam desenvolvido um novo método de abordagem das peças escritas e de suas encenações, que se pautava na ampla discussão e profunda análise de todos os aspectos das obras e, assim, conseguiram concretizar aquilo que Rosenfeld cita como o verdadeiro papel do diretor: "comunicar a peça 'em sua plena possibilidade de significação', dando-lhe 'a mais adequada e humana, tensa, encarnação possível" ${ }^{\prime 190}$. No palco, isso se manifestava por meio da extrema coerência e veracidade de toda a cenografia e do figurino, influenciados pela lógica do naturalismo na qual o meio, a atmosfera, eram condicionantes da ação humana.

\footnotetext{
${ }^{188}$ SLONIM, M. 1961. p.128

${ }^{189}$ Idem.

${ }^{190}$ ROSENFELD, A. 2006. p. 22
} 
É curioso notar que, de maneira geral, a recepção das peças de Tchékhov nos Estados Unidos foi bastante parecida à recepção que teve em seu próprio país. Como já referido, seu fracasso inicial, em grande medida, foi causado pelas técnicas de encenação empregadas e pela própria forma como havia sido interpretado seu texto, ainda com olhos formatados para o drama clássico e os vaudevilles que estavam amplamente em voga. As circunstâncias do teatro norte-americano eram similares àquelas criticadas por Stanislávski, como a importância demasiada dada aos atores, cuja afetação era tida como maestria de atuação e sentimentalismo. Essas tendências passariam a ser questionadas em solo americano só no século XX. A má recepção que a dramaturgia tchekhoviana recebeu de início parece, então, justificada.

As primeiras traduções da obra de Tchékhov a surgirem nos Estados Unidos datam de 1908, quando a revista estudantil Yale Courant publicou suas versões de O Jardim das Cerejeiras (The Cherry Garden) e de O Urso (The Bear). Em 1912, uma coletânea de suas peças foi publicada, traduzida por Marian Fell, e, a partir de então, diversas outras traduções se seguiram. Lawrence Senelick, tradutor e estudioso de Tchékhov, afirma que as traduções eram de qualidade bastante duvidosa, e mesmo Tennessee Williams sentia que as obras de Tchékhov nos Estados Unidos nunca haviam tido o tratamento que mereciam em inglês ${ }^{191}$.

A recepção das peças foi bastante negativa; a crítica afirmava que eram tediosas, inúteis, "a gallery of human waste represented by his fickle, spineless, drifting people"192. Acusaram o escritor de derrotista, pessimista, sem qualquer compromisso político ou moral, o que soava estranho ao público americano, que já criara em torno da alma eslava o mito do sofrimento e da luta política ${ }^{193}$. Dizia a

${ }^{191}$ SENELICK, L. 1997.

${ }^{192}$ Citado por MEISTER, Charles. Chekhov's Reception in England and America American. Slavic and East European Review, 12.1 de 1953: 109-121.

Tradução:

Uma galeria de dejetos humanos representada por suas pessoas fracas, inconstantes e flutuantes.

${ }^{193}$ Em 1905, nos Estados Unidos, teve início uma campanha para a libertação de Górki, que fora preso. Acreditando no potencial revolucionário dos norte-americanos, em 1906, Górki foi para lá tentar conseguir apoio para a revolução, mas fracassa quando os americanos descobrem que ele estava viajando com uma mulher com a qual não era casado. $\mathrm{O}$ fato, quase uma anedota, no entanto, mostra um pouco daquilo que a Rússia e os russos pareciam significar no imaginário americano.

HOHMAN, V. 2011. LOC 1200 . 
revista The Dramatist, em 1915:

\begin{abstract}
In place of plot and development there is a mere portrayal of inept circumstance. And in place of story there is nothing but the disconnected interests of several pairs of puppets... the whole reflects more the infirmities of the author than any other code or fad in contemporary drama... the antithesis of dramatic method. Surely the rankest American amateur would be suspected of softening of the cerebrum should he seriously submit such a sufflé to the producing manager. ${ }^{194}$
\end{abstract}

A ausência de um enredo marcante e centralizador, o caráter de títere circunstancial das personagens, são aspectos que, somente depois, seriam tidos como inovadores e profundamente inspirados. O que se percebe aqui é que o público e a cena teatral norte-americana como um todo ainda tinham outra concepção daquilo que o drama deveria ser. Somente uma minoria de escritores, críticos, atores e diretores demonstravam interesse em novas descobertas que fugissem ao modelo estabelecido pela Broadway.

A Broadway e o teatro, na verdade, eram vistos como indústria, um negócio verdadeiramente lucrativo - a ponto do governo, após a quebra da bolsa em 1929, criar um projeto de subsídio teatral, o Federal Theatre Project, sabendo das consequências terríveis que poderia acarretar a quebra dessa indústria. Um exemplo que Iná Camargo $\operatorname{Costa}^{195}$ oferece para entender a magnitude do caráter comercial que tinha é a empresa dos irmãos Schubert, que controlava 350 salas de espetáculos.

Como empreitadas comerciais, os teatros funcionavam segundo uma lógica de mercado que ditava salários baixos, longas jornadas de trabalho e o famoso lema The show must go on. Em meio a essas condições, era impossível manter um número alto de ensaios ou amplas discussões para cada peça, e o star system era quase inevitável. Parte substancial das peças encenadas dependia mais da fama do

${ }^{194}$ SENELICK, L. 1997.p.172

Tradução:

No lugar de enredo e desenvolvimento, há o mero retrato de circunstâncias inaptas. E no lugar da história, não há nada além dos interesses desconexos de vários pares de fantoches... o todo reflete mais as enfermidades do autor do que qualquer código ou moda do drama contemporâneo... a antítese do método dramático. Certamente, o amador americano de mais baixo escalão seria suspeitado de um afrouxamento do cérebro caso ele seriamente propusesse esse suflê para um gerente de produção.

${ }^{195}$ COSTA, I.C.Stanislávski na Cena Americana In: CAVALIERE, Arlete, e Elena VÁSSINA. Teatro Russo - Literatura e Espetáculo. São Paulo: Atelier Editorial, 2011. 
que do talento dos atores, de modo que a hierarquização das personagens era necessária.

Desde 1905, no entanto, já era conhecido o trabalho do TAM nos Estados Unidos, especialmente pelo sucesso que haviam tido em Berlim. Notícias das conquistas de Stanislávski chegavam por meio de publicações, e, depois da Revolução Russa de 1917, a curiosidade pelas inovações russas só aumentou.

Por outro lado, a dramaturgia europeia também lentamente ganhava espaço ${ }^{196}$ nas produções de companhias de imigrantes, especialmente no teatro iídiche. V. Hohman ${ }^{197}$ afirma que o realismo teatral era defendido pelos muitos judeus russos imigrantes que estavam nos Estados Unidos, apesar das correntes dominantes teatrais resistirem a isso. Jacob Gordin, cuja companhia conseguiu conquistar público até fora do meio imigrante, chegou a produzir peças de Gógol, Ibsen, Strindberg, Górki, Ostróvski e até mesmo uma adaptação de Ressurreição, de Tolstói. Hohman acredita que a presença desses grupos nos Estados Unidos ajudou a preparar o solo para a chegada do TAM e seu sucesso.

Ao lado disso, o início do século XX viu surgir também um movimento de pequenas companhias teatrais que tentavam fugir às formas propagadas pela Broadway. O Neighborhood Playhouse e o Washington Square Playhouse chegaram a encenar peças de Tchékhov, O pedido de casamento (1915), a primeira, e a segunda, O Urso (1915) e A Gaivota (1916), ambas recebidas muito mal pela crítica. Afirma Betti:

O surgimento de pequenas companhias como a Neihborhood Playhouse e os Washington Square Players, entre outras de estrutura semelhante, havia sido motivado pela insatisfação de diretores, atores e dramaturgos com as condições artísticas e o padrão interpretativo que

${ }^{196}$ HOHMAN, V. 2011. Loc 1256-1268.

By 1908, many American theatre artists had embraced the new forms of "realism" and "naturalism", which studies in psychology, economics, and anthropology had prompted; however, the other trends of European modernism had not yet made a significant impact on American theatre. Despite trends toward realism, American theatres still housed spectacular and romantic melodrama and vaudeville acts.

Tradução:

Em 1908, muitos artistas do teatro americano tinham aceitado as novas formas de "realismo" e "naturalismo", que estudos de psicologia, economia e antropologia propiciado; no entanto, as outras tendências do modernismo europeu ainda não haviam causado impacto sobre o teatro americano. Não obstante as tendências para o realismo, os teatros americanos ainda encenavam melodramas e vaudevilles românticos e espetaculares.

${ }^{197}$ Idem. 
predominavam no teatro comercial da Broadway. Essas companhias e inúmeras outras, desejosas de romper com as limitações artísticas que o comercialismo impunha, viriam a revelar-se um meio importante para a introdução e a difusão da dramaturgia de Tchékhov nos Estados Unidos 198.

Essas pequenas companhias, chamadas de little theatre movement (que duraram de 1908 a 1919) e derivadas do Theatre Arts Magazine, além de demonstrarem interesse crescente no desenvolvimento de um teatro profissional, como defendiam, em oposição ao comercial da Broadway, também se diferenciavam por sua estrutura: eram teatros menores, capazes de dedicar mais tempo a cada peça, inclusive por suas estruturas financeiras. Em seu programa, defendiam:

The elimination of the star system and the substitution of the ideal of the ensemble; a simplified, appropriate, decorative staging the development of a new body of poetic drama. And a sharp cleavage between commercial theatre and a new professional art theatre. ${ }^{199}$

Assim, quando Otto Kahn e Morris Gest ${ }^{200}$, também imigrante russo, resolveram levar o Teatro de Arte de Moscou a Nova Iorque, já estava em andamento um lento processo de renovação da cena teatral americana. Gest já havia obtido bastante sucesso ao levar ao palco a companhia russa ChauveSouris, entre outras companhias russas que obtiveram menor sucesso ${ }^{201}$. Para garantir a aceitação do

198 BETTI, M.S. .: CAVALIERE, Arlete, e Elena VÁSSINA. Teatro Russo - Literatura e Espetáculo. São Paulo: Atelier Editorial, 2011.p. 260.

${ }^{199}$ SENELICK, L.1997. p.173.

Tradução:

A eliminação do Star System e a substituição pelo ideal do ensemble; uma cenografia simplificada, apropriada e decorativa; o desenvolvimento de um novo corpo de drama poético. E uma clara cisão entre o teatro comercial e o novo teatro artístico profissional.

200 Hohman afirma que ele Gest foi uma figura essencial para a relação artística que a Rússia e os Estados Unidos estabeleceriam no teatro. Sua atuação como produtor, além de refrescar o cenário teatral com performances de grupos profissionais de teatro também se voltava ao estabelecimento de um teatro popular que fosse mais acessível às massas. Hohman acredita que não é dada a devida importância a essa figura, especialmente pelos meios não ortodoxos que empregava em suas maneiras de fazer negócio. Kahn também foi uma figura bastante importante na cena americana, sempre envolvido com o financiamento de projetos culturais importados da Europa, que achava importantes para elevação do gosto do público norte-americano. Também era imigrante, um banqueiro alemão, cuja fortuna havia sido feita na expansão ferroviária americana.

201 "The Russian companies and artists who came to America under the aegis of Kahn and/or Gest raised questions for American performing artists and critics about the nature of theatrical performance and the possibilities for its development." 
público americano, iniciou uma campanha publicitária intensa, que Iná Camargo Costa ${ }^{202}$ afirma ter sido digna dos padrões hollywoodianos. A imprensa passou a noticiar intensamente as conquistas teatrais de Stanislávski e foram encomendados a estudiosos livros de teatro russo, como é o caso de Oliver Sayler. ${ }^{203}$

Dado o contexto político americano e mundial, ainda enfrentaram resistência pelo possível "perigo bolchevique" que a companhia russa representava. Gest não poupou esforços para convencer a imprensa e, assim, o público, de que não havia perigo nenhum, utilizando não só o sucesso do Chauv-Souris como trampolim para Stanislásvki - que foi introduzido ao público durante uma de suas apresentações ${ }^{204}$-, mas também os muitos contatos de Otto Kahn no mundo político e das finanças para assegurar o público de que eram confiáveis. Um fato curioso é que Gest chegou a pedir que Stanislávski posasse com uma família falsa (de atores) para a imprensa, garantindo que passasse a imagem de homem correto ${ }^{205}$.

Quando a companhia enfim chegou, a ideia de uma ameaça comunista já havia sido

Tradução:

As companhias e os artistas russos que vieram à América sob o patronato de Kahn e/ou Gest levantaram a questão para os artistas performáticos e críticos americanos sobre a natureza da performance e as possibilidades para o seu desenvolvimento.

HOHMAN, V. 2011.LOC.1318

${ }^{202}$ COSTA, I.C.Stanislávski na cena americana. In.: CAVALIERE, Arlete, e Elena VÁSSINA. Teatro Russo - Literatura e Espetáculo. São Paulo: Atelier Editorial, 2011

${ }^{203}$ SAYLER, O.M. The Moscow Art Theatre Series of Russian Plays. 1921. A cópia deste livro e outros do mesmo autor está disponível para download em archive.org

Sayler também foi um dos responsáveis pela fama americana do TAM. Foi por meio de seus livros e reportagens que o público americano se manteve em contato com as pesquisas teatrais russas mesmo após a revolução.

${ }^{204}$ Balieff gave Stanislavsky a bouquet and Stanislavsky spoke briefly in Russian. As rendered by an interpreter, what he said was a graceful and touching tribute from sorrowing Russian toward beneficent America. According to Balieff, the interpreter missed the point, which was that women of America are the most beautiful in the world, especially those who were present.

Tradução:

Balieff deu um buquê para Stanislávski e Stanislávski falou brevemente em russo. Segundo um intérprete, aquilo que ele havia dito era um comovente e gracioso tributo à America beneficente da pesarosa Rússia. De acordo com Balieff, o intérprete não entendeu o ponto principal, que era que as mulheres da América eram as mais belas do mundo, especialmente aquelas lá presentes.

CORBIN, J. Chauve-Souris, Fourth Version, New York Times, 5 de Janeiro, 1923. Apud. HOHMAN, V. loc. 2051.

${ }^{205}$ HOHMAN, V. 2011. LOC. 2089. 
dissipada $^{206}$ e, no meio teatral, já havia se difundido um interesse generalizado nas novas técnicas e linhas de pesquisa que o TAM estava propondo. De modo geral, as encenações de Tchékhov pelo TAM foram um estrondoso sucesso.

A imprensa deu conta de registrar as mais importantes unanimidades americanas a respeito dos espetáculos do TAM: a barreira linguística não prejudicou em nada a fruição dos espetáculos porque se tratava de 'entender' e 'sentir' o que acontecia em cena; no palco assistia-se a uma 'fatia da vida' e não a uma 'peça de teatro'; os atores 'vivem' seus papéis, não os 'interpretam'; e, independentemente de haver hierarquização de personagens, todos os atores têm igual importância na realização do espetáculo, o que resulta do trabalho conjunto (ensemble), coisa jamais vista nos Estados Unidos. ${ }^{207}$

Como aparece resumido no excerto acima, a aceitação da companhia russa foi unânime. A turnê, que durou de janeiro de 1923 a abril de 1924 e contou com 380 performances em 12 cidades americanas, teve que ser estendida inúmeras vezes para dar conta da demanda. Um repórter do New York Herald, em novembro de 1923, escreveu:

As one who had never attended the performances out of sheer patriotism and disgust for bellicose Russian artism, we hereby eat dirt. For us, at any rate a new standard of acting for those who fed upon the American stage, to understand what heights this art can reach. It is impossible to convey, in a meager and hurried description of this sort of juicy, full ripe nature of the interpretive ability of these players. ${ }^{208}$

É interessante notar como a campanha de Gest e Kahn foi eficiente em lidar com as possíveis

${ }^{206}$ A imprensa os chamavam de "white russians" ou russos brancos.

${ }^{207}$ COSTA, I.C. In: .: CAVALIERE, Arlete, e Elena VÁSSINA. Teatro Russo - Literatura e Espetáculo. São Paulo: Atelier Editorial, 2011 p. 173.

${ }^{208}$ GORDON, Mel. Stanislavsky in America: An actor's workbook. New York: Routledge, 2010.LOC 108. Kindle.

Tradução:

Como alguém que nunca havia atendido a uma dessas performances por puro patriotismo e nojo pelas artes belicosas da Rússia, nós agora comemos terra. Para nós, de qualquer forma, um novo padrão de atuação para aqueles que se alimentavam do palco americano, para entender as alturas que essa arte pode alcançar. É impossível expressar numa corrida e mera descrição o tipo de natureza madura e suculenta da habilidade interpretativa desses atores. 
resistências ao TAM por razões políticas, lembrando que, após a Revolução de 1917, as tensões entre Estados Unidos e Rússia estavam em um crescendo.

As reações que surgiram ao encantamento com as conquistas de Stanislávski foram inúmeras e frutíferas, muitas companhias teatrais surgiram defendendo a possibilidade de um teatro de arte americano, alguns críticos afirmavam que seria uma empreitada fácil, agora que a tinham como possibilidade. Inúmeras escolas foram abertas, muitas com os próprios atores do TAM, que haviam ficado na América. O American Laboratory Theatre, por exemplo, criado somente seis meses após o início da turnê do TAM, abrigara Richard Boleslávski e Maria Uspénskaia e se focou em desenvolver uma linha de pesquisa que unisse as novas conquistas a materiais verdadeiramente americanos. A pesquisa, no entanto, se frustra, “a desejada expressão do chamado ‘espírito americano’ não havia se desenvolvido "209.

A assimilação das técnicas provindas da Rússia, como se pode ver, se dava por meio de um intenso desejo nacionalista de desenvolver uma voz própria no teatro americano. Rapidamente, os diferentes estúdios começam a investir na produção de jovens dramaturgos americanos, que acabaram por se provar material mais frutífero para as companhias.

Ao mesmo tempo, até a década de 1930, o número de encenações de peças de Tchékhov nos mais diferentes teatros, especialmente naqueles da Broadway, cresceu substancialmente ${ }^{210}$. Senelick afirma que esse fenômeno era, em parte, decorrente de uma espécie de valor simbólico que as peças tchekhovianas agregavam aos grupos que a produzissem, pois estabeleciam uma linha de contato entre as companhias e o TAM. De antítese do dramático, Tchékhov se tornara sinônimo de audácia artística nos meios cultos do teatro americano. O que cabe pontuar é que a maioria das produções que suas peças tiveram tinha como referência crítica as performances de Stanislávski, quem engatilhara a mudança na recepção de suas obras.

O caráter comercial da absorção da obra tchekhoviana, no entanto, causava distorções em suas leituras, que ganharam, especialmente na década de 1950, um caráter mais doméstico e

209 BETTI, M.S. In: CAVALIERE, Arlete, e Elena VÁSSINA. Teatro Russo - Literatura e Espetáculo. São Paulo: Atelier Editorial, 2011. p. 262

${ }^{210}$ A produção do McClintic Theatre de As Três Irmãs na Broadway, por exemplo, teve uma turnê de 39 semanas, com o total de 122 apresentações. Foi a mais longa turnê de uma produção americana de Tchékhov. Senelick argumenta que havia uma relação de identificação entre a leitura que faziam do conteúdo da peça e o período de guerra pelo qual passava a sociedade americana. 
sentimental $^{211}$, que se tornava corrente na nova dramaturgia. As limitações objetivas do trabalho na Broadway ainda eram um empecilho para o desenvolvimento de encenações que considerassem, de fato, todas as características formais de seus dramas. É por isso que, como Betti ${ }^{212}$ afirma, o solo mais fecundo para sua dramaturgia e as técnicas de Stanislávski tenha sido o dos teatrinhos, pois é a partir deles que a nova geração de dramaturgos americanos se desenvolveria, sempre orientada à criação de algo verdadeiramente americano.

O sucesso das peças tchekhovianas estava, portanto, intrinsecamente ligado ao método de Stanislávski, que condicionava sua leitura e seus parâmetros de interpretação. Senelick afirma que a ausência de uma tradição anterior de suas peças teria tornado mais fácil a assimilação desses parâmetros externos, dado que, até o TAM, as peças eram vistas como impossíveis de serem encenadas.

A junção do contato com as novas conquistas a um momento na história do teatro americano, no qual o desejo de rompimento com as tradições comerciais estava ganhando ímpeto, resultou numa onda de novas escolas, companhias e dramaturgos, que se estabeleceriam como a voz do teatro profissional americano a partir das décadas de 1940 e 1950. Grandes nomes do cânone dramatúrgico americano, como Tennessee Williams, Clifford Odets e Eugene O-neill, surgiram a partir desse contexto de abertura para questionamentos e renovações.

A hipótese de que na própria escritura de Tennessee Williams se encontrem rastros não só da forma tchekhoviana, mas também da visão orgânica e detalhista voltada à coesão total dos elementos dramáticos de Stanislávski, parece ser historicamente possível. Como se verá na análise mais detida dos expedientes empregados pelo dramaturgo em suas peças, muitas das rubricas e descrições que ele incorpora em seu texto parecem partir de um mesmo entendimento daquilo que era a linguagem teatral e como esta deveria ser trabalhada. Assim, é no cuidado com o detalhamento de cenários, de sons que permeiam a peça, ao sugerir uma série de relações semânticas, a escolha minuciosa das características da vestimenta das personagens, de suas poses, gestos e movimentos, que parecem surgir referências não somente a Tchékhov, mas ao Tchékhov do TAM.

\footnotetext{
211 Era comum no teatro norte-americano dessa época peças que abordassem o tema da família e da vida doméstica, revestidos de um sentimentalismo similar àquele encontrado no drama burguês. Ao mesmo tempo, dramaturgos como Eugene O'neill, Tennessee Williams e Edward Albee, expandiram as possibilidades críticas de tal temática com peças que problematizariam não só a estrutura familiar da sociedade americana, mas todo o sonho americano e suas promessas.
}

${ }^{212}$ SAYLER, O.M. The Moscow Art Theatre Series of Russian Plays. 1921 - Disponível para download em Archive.org 
Para melhor perceber as implicações textuais dessa hipótese, vale analisar de forma detida a peça em um ato 27 Wagons Full of Cotton $^{213}$. A escolha por esta se deu em função da clareza com a qual esses expedientes aparecem no texto, como também por seu formato breve, que permite examinar de perto todas as suas manifestações. Para o bem da comparação, se utilizará também a partitura de palco de Stanislávski para a peça As Três Irmãs, por sua análise já ter se dado no capítulo anterior, abreviando a necessidade de explicações.

A fábula de 27 Wagons Full of Cotton pode ser resumida como a história de um agricultor de algodão que, para melhorar suas chances de competição com o sindicato de plantadores de algodão, que estava comprando todas as terras à sua volta, ateia fogo ao seu descaroçador, obrigando-os a terceirizarem a função para ele. O título da peça provém exatamente disso: impossibilitados de realizar o trabalho de descaroçar 27 carroças de algodão, passam-no a Jake Meighan. Sua esposa, Flora Meighan, desconfia que seu marido tenha sido o culpado, mas é convencida a se manter quieta. Quando o Sr. Silva Vicarro, superintendente da sindicato da plantação, visita sua casa para pedir-lhe que faça o trabalho, Flora, no entanto, deixa escapar pistas sobre o possível envolvimento de seu marido com o incêndio. Após uma longa conversa entre Flora e Vicarro, que se desenrola enquanto seu marido faz o serviço que lhe fora pedido, chegam a um acordo silencioso, que permanece segredo para o marido, no qual o trabalho continuaria a ser repassado a Jake, contanto que Flora servisse Vicarro sexualmente.

A fábula, no entanto, se distancia da dramaturgia tchekhoviana por conter elementos de ação mais evidentes, que a um só tempo impulsionam a tensão no espectador e se diluem na forma sugestiva por meio da qual são comunicados, impedindo que se configurem como conflitos tradicionais. Por outro lado, como em Tchékhov, os acontecimentos que poderiam ter peso dramático, como o incêndio e as cenas de abuso sexual, são todas deixadas para além do palco, chegando ao espectador somente por meio de sugestões sonoras. O incêndio, por exemplo, é comunicado a Flora e ao público por sons de explosões e pelas vozes de vizinhos que correm para ver o que aconteceu.

"FLORA. (...) Ja-ay-a-a-ake! (a cow moos in the distance with the same inflection. There is a muffled explosion somewhere about half a mile away. A strange flickering glow appears, the reflection of a burst of flame. Distant voices are heard exclaiming.)"214

${ }^{213}$ WILLIAMS, T. 1949. 
A sugestão de estupro, se dá dentro da casa, que permanece fechada para a visão do espectador, sendo sugerida pelos gritos de Flora e, depois, pela sua aparência devastada na cena seguinte.

FLORA. Don't follow. Please don't follow! (jShe sways uncertainly. He presses his hand against her. She moves inside. He follows. The door is shut quietly. The gin pumps slowly and steadily across the road. From inside the house there is a wild despairing cry. A door is slammed. The cry is repeated more faintly.)

Curtain $^{215}$

Scene III

It is about nine o'clock the same evening. Although the sky behind the house is a dusky rose color, a full September moon of almost garish intensity gives the front of the house a ghostly brilliance. Dogs are howling like demons across the prostrate fields of the Delta.

The front porch of the MEIGHAN is empty.

After a moment the screen door is pushed slowly open and FLORA MEIGHAN emerges gradually. Her appearance is ravaged. Her eyes have a vacant limpidity in the moonlight, her lips are slightly apart. She moves with her hands stretched gropingly before her till she has reached a pillar of the porch. There she stops and stands moaning a little. Her hair hangs loose and disordered. The upper part of her body is unclothed except for a torn pink band about her breasts. Dark streaks are visible on the bare shoulders and arms and there is a large discoloration along one cheek. A dark trickle, now congealed, descends from one corner of her mouth. These more apparent tokens she covers with one hand when JAKE comes up on the porch. He is now heard singing to himself. ${ }^{216}$

${ }^{214}$ WILLIAMS, T. 1949.p. 9

Tradução:

FLORA. (...) Ja-ay-a-a-ake! (uma vaca muge na distância com a mesma inflexão. Há alguns kilômetros há uma explosão. Um estranho brilho tremulanteaparece, o reflexo da explosão da chama. Vozes exclamando são ouvidas na distância.)"

${ }^{215}$ Ibidem.p.28

Tradução:

FLORA. Não me siga. Por favor não me siga!(Ela se balança incerta. Ele aperta sua mão contra ela. Ela entra. Ele a segue. A porta é fechada silenciosamente. O descaroçador pode ser ouvido lenta e ritmicamente do outro lado da estrada.De dentro da casa há um grito desesperador. Uma porta é batida. O grito se repete mais baixo.)

Cortina.

${ }^{216}$ WILLIAMS, T. 1949.p. 28

Tradução:

Cena III

È quase nove horas da mesma noite. Apesar do céu atrás da casa estar de uma cor rosa sombria, uma lua cheia de setembro, de uma intensidade quase espalhafatosa, dá um brilho fantasmagórico à frente da casa. Cães estão uivando como demônios pelos campos prostrados do Delta. A varanda da frente da casa do MEIGHAN está vazia. 
Não se discorrerá sobre os demais elementos que aproximam e afastam a forma dramatúrgica de Tennessee Williams à de Tchékhov por estes já terem sido tratados em outros capítulos. Vale voltar a atenção aqui somente àquilo que sugere uma aproximação entre Tennessee e a forma stanislasvkiana de lidar com a linguagem teatral.

Já nas rubricas e indicações de cena dos excertos acima, transparece o controle que Tennessee parece ter sobre aquilo que quer comunicar para seu espectador por meio dos diferentes níveis de linguagem de palco. As direções que insere em seu texto para a movimentação das personagens e sua interação, os diversos sons que devem estar presentes no plano de fundo e o detalhamento do cenário aliado à especificação da impressão que este deve causar, tudo isso se aproxima da visão de Stanislávski e do TAM expressa durante a turnê - muito embora aquilo que foi apresentado não condizia às pesquisas mais recentes do grupo.

A leitura dos trechos transcritos acima demonstra claramente o detalhamento que o dramaturgo dá à cena toda, incluindo, de certa forma, no texto, a partitura do espetáculo. A peça, mesmo quando lida, acaba produzindo uma percepção visual muito forte, pois os dados fornecidos ao leitor chegam a igualar aqueles contidos em um romance. Os textos de Tchékhov, diferentemente, guardam comentários bem mais sutis, notando somente o essencial para a sugestão de atmosferas. Os gestos que utiliza largamente, são menos detalhados também, somente pontuam o frequente desencontro entre as falas e as correntes subjacentes da psyché de suas personagens.

Detalhamento similar ao de Tennessee ocorre somente quando confrontado o texto de Tchékhov com as anotações de palco de Stanislávski, que contêm um passo a passo minucioso de tudo aquilo que os atores devem fazer, com sugestões acerca do estado de espírito que os animam, além de notas como o som de grilos e demais elementos contextuais.

Outra característica, que diferencia Tennessee de Tchékhov e de Stanislávski, é como

Depois de um tempo, a porta de tela da frente é lentamente aberta e FLORA MEIGHAN aparece gradualmente. Sua aparência está devastada. Seus olhos têm uma limpidez vazia à luz da lua, seus lábios estão entreabertos. Ela se move com as mãos esticadas à sua frente, tateando, até que se agarra ao pilar da varanda. Lá ela para gemendo um pouquinho. Seu cabelo pende solto e desarrumado. A parte de cima de seu corpo está despido, exceto por uma faixa rosa que cobre seus seios. Marcas escuras são visíveis em seus ombros e braços, e há uma grande descoloração em uma de suas bochechas. Uma gota escura, agora congelada, escorre pelo canto de sua boca. Essas provas mais evidentes ela esconde com uma mão quando JAKE sobe na varanda. Ele canta para ele mesmo. 
elementos da psicologia interna das personagens se encontram indicados em elementos da atmosfera (stimmung) da peça de forma mais intensa. Essa técnica que projeta a subjetividade de personagens em elementos como o clima e a paisagem, submetendo-os a elementos pessoais, é remanescente das formas românticas de expressão e, em Tennessee, ganha contornos quase expressionistas. A casa com seu caráter fantasmagórico é um detalhe que ajuda a compor o potencial comunicativo da atmosfera na qual deve ser entendido o estupro (que só pode ser suposto) de Flora e já anuncia aquilo que o dramaturgo formularia depois como teatro plástico. A metamorfose que ocorre com a representação da casa e seu significado é melhor entendido quando comparadas as duas descrições que faz do cenário.

O texto inicia-se com a seguinte rubrica:

SCENE: the front porch of the Meighans' cottage near Blue Mountain, Mississippi. The porch is narrow and rises into a single narrow gable. There are spindling white pillars on either side supporting the porch and roof and a door of Gothic design and two Gothic windows on either side of it. The peaked door has an oval of richly stained glass, azure, crimson, emerald and gold. At the windows are fluffy white curtains gathered coquettishly in the middle by babyblue satin bows. The effect is not unlike a doll's house.

\section{SCENE I}

It is early evening and there is a faint rosy dusk in the sky. Shortly after the curtain rises, JAKE MEIGHAN, a fat man of sixty, scrambles out the front door and races around the corner of the house carrying a gallon can of coal-oil. A dog barks at him. A car is heard starting and receding rapidly in the distance. A moment later FLORA calls from inside the house. ${ }^{217}$

Logo de início, nota-se o detalhamento descritivo de Tennessee em relação ao palco: a casa dos

${ }^{217}$ WILLIAMS, T. 1949.p.9

Tradução:

CENA: Na varanda da frente da casa dos MEIGHANS, perto de Blue Mountain, Mississippi. A varanda agora é estreita e se ergue para um só frontão estreito. Há pilares alongados nos dois lados, sustentando a varanda e o telhado e uma porta de design gótico e duas janelas góticas em cada um de seus lados. A porta pontiaguda tem um vitral oval, ricamente colorido, índigo, carmesim,, esmeralda e dourado. Nas janelas há cortinas brancas e fofas, unidas coquetemente ao meio com laços de cetim azul bebê. $O$ efeito não é diferente daquele de uma casa de bonecas.

CENA I

É o início da noite e há um lusco-fusco róseo no céu. Pouco depois da cortina se erguer, JAKE MEIGHAN, um homem gordo de sessenta anos, sai apressadamente da porta da frente e corre para o lado da casa carregando um galão de óleo de carvão. Um cachorro late para ele. Ouve-se um carro sendo ligado e sumindo rapidamente na distância. Um momento depois, FLORA chama do lado de dentro da casa. 
Meighan deve ter pilares e janelas góticas com cortinas brancas, que lembrem uma casa de bonecas. Essa impressão sobre a casa se relaciona diretamente às qualidades de Flora, que age como uma criança durante sua peça, característica que só é reforçada pelo apelido "Baby" que o marido lhe dá.

O uso que faz dos diversos sons na primeira cena - o latido do cachorro e o barulho do carro também é muito característico de uma linguagem teatral levada a seu extremo. Como se vê em Tchékhov e e Stanislávski, exercem função significante total, sendo repassado a eles dados importantes para o desenvolvimento do drama - um exemplo clássico desse uso em Tchékhov é o tiro que se ouve fora do palco em A Gaivota, assinalando o suicídio de Konstantín.

No excerto acima, vê-se também que Tennessee especifica as qualidades físicas dos personagens, que ganham relevância dentro da peça, como o tamanho de Jake e sua leve penugem loira, que assume um tom condescendente perante Vicarro por ser menor. Nas peças de Tchékhov, há poucas especificações dessa natureza no texto escrito, apesar do escritor especificar muitos dos seus desejos sobre a encenação por meio de cartas, demonstrando seu aproveitamento das diferentes facetas da linguagem teatral.

\section{О. Л. КНИППЕР \\ 02 января 1901 г.}

Опиши мне хоть одну репетицию «Трех сестер». Не нужно ли чего прибавить или что убавить? Хорошо ли ты играешь, дуся моя? Ой, смотри! Не делай печального лица ни в одном акте. Сердитое - да, но не печальное. Люди, которые давно носят в себе горе и привыкли к нему, только посвистывают и задумываются часто. Так и ты частенько задумывайся на сцене, во время разговоров. Понимаешь?

$[\ldots]^{218}$

${ }^{218}$ http://www.litmir.me/br/?b=91140\&p=91

Tradução:

Descreva-me ao menos um ensaio de "As três irmãs". Não é preciso adicionar ou tirar algo? Você está interpretando bem, minha querida? Oh, veja! Não faça uma cara triste em nenhum dos atos. Brava sim, mas não triste. As pessoas que há tempos carregam consigo a tristeza e estão acostumadas a ela apenas andam por aí assobiando e se perdem em pensamentos com frequência. Se perca você também em pensamentos no palco, nos momentos de conversa. Entende? 


\section{И. А. ТИХОМИРОВУ}

14 января 1901 г.

Многоуважаемый Иоасаф Александрович, только что получил Ваше письмо, Вы меня очень порадовали, спасибо Вам громадное. Вот ответы на Ваши вопросы: 1) Ирина не знает, что Тузенбах идет на дуэль, но догадывается, что вчера произошло что-то неладное, могущее иметь важные и притом дурные последствия. А когда женщина догадывается, то она говорит: "Я знала, я знала".

2) Чебутыкин поет только слова: "Не угодно ль этот финик вам принять..." Эти слова из оперетки, которая давалась когда-то в Эрмитаже. Названия не помню, справиться, если угодно, можете у архитектора Шехтеля (собств. дом, близ церкви Ермолая). Другого ничего Чебутыкин петь не должен, иначе уход его затянется.

3) Действительно, Соленый думает, что он похож на Лермонтова; но он, конечно, не похож - смешно даже думать об этом... Гримироваться он должен Лермонтовым. Сходство с Лермонтовым громадное, но по мнению одного лишь Соленого.

$[\ldots]^{219}$.

\section{А. Л. ВИШНЕВСКОМУ}

17 января 1901

Милый Александр Леонидович, большое Вам спасибо за письмо и поздравление. В III акте, конечно, Вы можете явиться в форменной тужурке, это так; но почему во II акте Вы входите в гостиную в шубе? Почему? Впрочем, быть может, это так выходит. Как

${ }^{219}$ http://www.anton-chehov.info/pisma-za-1901-god-chast-2.html

Tradução:

Para I. A. Tikhomirov

14 de janeiro de 1901.

Digníssimo Iosaf Aleksandrovich, acabo de receber a sua carta, você me alegrou muito, muitíssimo obrigado. Eis as respostas às suas perguntas: 1) A Irina não sabe que o Tuzenbakh vai duelar, mas suspeita que ontem aconteceu algo errado, capaz de ter consequências importantes e, além disso, ruins. E quando a/uma mulher acerta uma suspeita, ela diz então: "eu sabia, eu sabia".

2) Tchebutíkin canta apenas a letra: "Você não aceitaria estas tâmaras..." Esta é a letra de uma operetazinha que se deu no Hermitage. Não me lembro do seu nome, você pode perguntar, caso assim deseje, ao arquiteto Shekhtel (casa privada, próxima à igreja Iermolaia). Tchebutíkin não deve cantar mais nada, do contrário a sua partida será atrasada.

3) De fato, Solioni pensa que ele se parece com Lermontov; mas ele, é claro, não se parece - é até ridículo pensar nisso... Ele deve se maquiar como Lermontov. A semelhança com Lermontov é enorme, mas apenas na opinião de Solioni. 
знаете. ${ }^{220}$

\section{О. Л. КНИППЕР}

17 января 1901 г.

Конечно, третий акт надо вести тихо на сцене ${ }^{*}$, чтобы чувствовалось, что люди утомлены, что им хочется спать... Какой же тут шум? ${ }^{221}$

\section{О. Л. КНИППЕР}

20 января (2 февраля) 1901 г.

Милая актрисуля, эксплоататорша души моей, зачем ты прислала мне телеграмму? Уж лучше бы про себя телеграфировала, чем по такому пустому поводу. Ну как «Три сестры»? Судя по письмам, все вы несете чепуху несосветимую. В III акте шум... Почему шум? Шум только вдали, за сценой, глухой шум, смутный, а здесь на сцене все утомлены, почти спят... Если испортите III акт, то пьеса пропала, и меня на старости лет ошикают. Тебя Алексеев в своих письмах очень хвалит и Вишневский тоже. Я хотя и не вижу, но тоже хвалю. Вершинин произносит «трам-трам-трам»- в виде вопроса, а ты - в виде ответа, и тебе это представляется такой оригинальной штукой, что ты произносишь это «трам-трам» с усмешкой... Проговорила «трам-трам» - и засмеялась, но не громко, а так, чуть-чуть. Такого лица, как в «Дяде Ване», при этом не надо делать,

${ }^{220}$ http://feb-web.ru/feb/chekhov/texts/sp0/pi9/pi9-1833.htm

Tradução:

Para A. L. Vishnevsky

17 de janeiro de 1901

Caro Aleksandr Leonidovitch, muito obrigado pela carta e pelas congratulações. No ato III, é claro, você pode aparecer com uma jaqueta de uniforme, tudo certo; mas por que no ato II você vai entrar na sala de estar vestindo um casaco de pele? Por quê? Contudo, pode ser que funcione.Você que sabe.

${ }^{221}$ http://www.litmir.me/br/?b=192340\&p=54

Tradução:

Para O. L. Knipper

17 de janeiro de 1901

É claro, deve-se conduzir o terceiro ato silenciosamente no palco, para que se sinta que as pessoas estão exaustas, que elas querem dormir... Que barulho caberia aqui? 
а моложе и живей. Помни, что ты смешливая, сердитая. Ну, да я на тебя надеюсь, дуся моя, ты хорошая актриса.

Я же говорил тогда, что труп Тузенбаха проносить неудобно по Вашей сцене, а Алексеев стоял на том, что без трупа никак нельзя. Я писал ему, чтобы труп не проносили, не знаю, получил ли он мое письмо. ${ }^{222}$

A escolha por incluir no texto dramatúrgico essas características denota um controle maior de Tennessee sobre a encenação de suas peças. Em suas rubricas é possível notar elementos que parecem extrapolar o âmbito dramatúrgico, resvalando na esfera do romance. A penugem loira que Jake deveria ter é um detalhe que dificilmente seria notado no palco, mas que é incluído como item necessário. Lembra-se, então, novamente, daquilo que dissera Raymond Williams sobre a tentativa de testar a dramaticidade de detalhes que seriam característicos do gênero épico.

Para ilustrar as semelhanças de detalhes que Tennessee fornece em seu texto, transcrevem-se abaixo o início da partitura de palco de Stanislávski para a peça As Três Irmãs e, em seguida, a rubrica de Tchékhov para a mesma, traduzidas do original para o português por Tieza Tissi:

À subida da cortina as estão sozinhas no palco - Olga, no erker corrige apressadamente os cadernos das alunas (para se livrar o quanto antes). Irina organiza o balcão de vidro (erker) que acaba de ser aberto, após o inverno. Coloca plantas, pendura gaiolas com pássaros, troca-lhes a comida e a água - enfia-lhes na gaiola os brotos recém colhidos do cume das árvores. Sobre a mesa há linha, agulha e a gravata de Andrei que ela estava consertando a seu pedido. Macha, com um chapéu na mão, lê um livro, semi-deitada em uma cama turca. O livro está sobre a mesinha turca. Ela corta as páginas com um grampo do chapéu. Com ânimo primaveril, nos

${ }^{222}$ http://feb-web.ru/feb/chekhov/texts/sp0/pi9/pi9-1873.htm

Tradução:

A O. L. Knipper

20 de janeiro (2 de fevereiro) de 1901

Querida atrizinha, exploradora da minha alma, por que você me enviou um telegrama? Certamente, teria sido melhor me telegrafar a seu respeito e não por uma razão tão vã. E como vai "As três irmãs"? Julgando pelas cartas, todos vocês estão dizendo completos absurdos. Barulho no ato II... Por que barulho? Barulho apenas à distância, fora do palco, barulho abafado, vago; e aqui no palco todos exaustos, quase dormem... Se vocês estragarem o ato III, a peça acaba, e vão me vaiar na minha velhice. Em suas cartas, o Alekseiev te elogia muito, e o Vichnevski também. E ainda que eu não te veja, também elogio. O Verchinin pronuncia "tram-tram-tram" em forma de pergunta, e você, em forma de resposta, e isso te soa como uma piada tão original que você pronuncia este "tram-tram" com um sorrisinho... Disse "tram-tram" e começou a rir, mas não alto, mas assim, baixinho. Não faça, aliás, aquela expressão como em "Tio Vânia", mas mais jovem e vivaz. Lembre-se de que você é divertida e irritadiça. Bem, eu confio em você, minha querida, você é uma boa atriz.

Eu disse afinal, naquela oportunidade, que seria inapropriado carregar o cadáver do Tuzenbakh através do palco; mas o Alekseiev insistiu que sem cadáver não poderia ser. Eu o escrevi para que não carregassem o cadáver, não sei se ele recebeu ou não a minha carta. 
bastidores, um violino toca (mal) uma sonora sonata. De vez em quando erra e repete (estuda) várias vezes. É Andrei. Cortina - durante algum tempo, pausa - Ólia suspirou, largou os cadernos, espreguiçou-se e, para descansar, aproximou-se da janela, beijou Irina (como uma mãe, admirando-a) e apoiou o cotovelo no batente próximo ao erker, olhando para longe. Irina costura a gravata. 223

Do texto de Tchékhov:

Na casa dos Prózorov. Uma sala de visitas com colunas, através das quais se vê um salão. Meio-dia. Lá fora está ensolarado e alegre. No salão estão pondo a mesa para o café da manhã. Em seu uniforme azul de professora do colégio feminino, Olga corrige os cadernos das alunas o tempo todo, em pé ou andando. Macha, de vestido preto, está sentada com um chapéu sobre os joelhos e lê um livro. Irina usa um vestido branco e está em pé, pensativa. ${ }^{224}$

A diferença entre ambos é nítida, também pelas diferentes funções que cada um dos textos tem - texto cênico e partitura teatral. Porém, é possível perceber nesse pequeno exemplo, como Stanislávski adiciona informações sobre as personagens, antecipando elementos que só se tornam mais claros no desenrolar da peça. Assim, transparece no comportamento gestual de Olga seu cansaço em relação ao trabalho de professora; deve parecer em palco que ela quer se livrar logo da tarefa que executa. O carinho maternalque tem por Irina também já é antecipado logo na primeira cena. No texto de Tchékhov, encontram-se somente detalhes que contribuem para a qualificação das personagens de maneira geral, como suas vestimentas significantes, a roupa de professora ou o vestido branco, que alude a uma certa leveza pueril que depois se percebe em Irina.

Nota-se, então, como as indicações de cena de Tennessee estão muito mais próximas da composição de Stanislávski do que da composição sugerida pelotexto de Tchékhov, deixando poucos espaços em aberto para o encenador trabalhar. Sob sua "direção" contida na dramaturgia, a coesão total dos diversos estratos significativos da peça já está indicada, e os dados que deseja antecipar para seu público, projetados na esfera dos detalhes simbólicos, estão sob seu controle.

${ }^{223}$ BARBOSA, Tieza Tisse. As partituras de Stanislávski para As Três Irmãs de Tchékhov: Tradução e análise da composição espacial da encenação.São Paulo: 2012. Dissertação de mestrado em Literatura e Cultura Russa - Faculdade de Filosofia, Letras e Ciências Humanas, Universidade de São Paulo.p.101-103

${ }^{224}$ BARBOSA, T.T. 2012. p.100 


\section{Mais um exemplo:}

JAKE. I ain't been off th'front po'och! Not since supper! Understand that, now?

FLORA. Jake, honey, you've gone out of your mind!

JAKE. Maybe so. Never you mind. Just get that straight an'keep it in you haid. I ain't been off the porch of this house since supper.

FLORA. But you sure as God was off it! (he twists her wrist). Ouuuu! Stop it, stop it stop it!

JAKE. Where have I been since supper?

FLORA. Here, here! On th'porch! Fo'God's sake, quit that twistin'!

JAKE. Where have I been?

FLORA. Porch! Porch! Here!

JAKE. Doin’ what?

FLORA. Jake!

JAKE. Doin' what?

FLORA. Lemme go! Christ, Jake! Let loose! Quiet twisting, you'll break my wrist!

JAKE. (laughing between his teeth). Doin' what? What doin'? Since supper?

FLORA. (crying out). How in hell do I know!

JAKE. 'Cause you was right here with me, all the time, for every second! You an' me, sweetheart, was sittin' here together on th'swing, just swingin' back an' forth every minute since supper! You got that in your haid good now?

FLORA. (whimering). Le'go!

JAKE. Got i? In your haid good now?

FLORA. Yeh, yeh, yeh- leggo!

JAKE. What was I doin', then?

FLORA. Swinging! For Christ's sake - swinging! (He releases her. She whimpers and rubs her wrist but the impression is that the experience was not without pleasure for both parties. She groans and whimpers. He grips her loose curls in his hand and bends her head back. He plants a long wet kiss on her mouth. $)^{225}$

${ }^{225}$ WILLIAMS, T. 1949. p.11-12 
Toda essa cena de aparente agressão, no final, é deixada em aberto pela sugestão de que, talvez, as personagens gostem desse tipo de demonstração de afeto, como se fosse um jogo. No entanto, mais do que isso, a mera "impressão" sugerida por Tennessee pela maneira como Flora esfrega seu pulso machucado é exatamente o que deixará o final da peça em aberto. O jogo agressivo de sedução que tem com seu marido, assim caracterizado pelo pequeno gesto de Flora nessa cena, sugere que o acordo que se estabelece entre ela e Vicarro, no final, seja de seu agrado.

Como elementos sensíveis, que se dão no mundo concreto do palco e não como sugestão abstrata, todos os detalhes aqui expostos são essenciais para a composição das atmosferas das peças. Eles contribuem para o sentimento de todo orgânico e de uma situação total que deve se manifestar no palco; em Tennessee e Stanislávski, talvez, de maneira mais evidentemente realista do que em Tchékhov, cuja principal qualidade apontada pela fortuna crítica foi a de impressionista. Tchékhov era impressionista, Stanislávski o fez realista, e é o Tchékhov realista de Stanislávski que é sentido na composição de Tennessee.

As qualidades que fazem de Tchékhov impressionista, a sutileza de sua escrita, seu caráter sugestivo e reticente (mesmo suas rubricas parecem se desenvolver negativamente, ou seja, sob o

Tradução:

JAKE. Eu não saí desta varanda! Não saí desde a janta! Entendeu isso agora?

FLORA. Jake, querido, você perdeu as estribeiras!

JAKE. Pode ser que sim. Mas não é da sua conta. Só entenda e mantenha isso claro na sua cabeça. Eu não saí de cima da varanda dessa casa desde a janta.

FLORA. Mas juro por Deus que você saiu! (ele torce o pulso dela). Aiiii!Para, para, para com isso!

JAKE.Onde eu estive desde a janta?

FLORA. Aqui, aqui!Na varanda! Pel'amor de Deus, deixa de torcer!

JAKE. Onde eu estive?

FLORA. Varanda! Varanda! Aqui!

JAKE. Fazen'o que?

FLORA. Jake!

JAKE.Fazen'o que?

FLORA. Me larga! Jesus, Jake! Me solta!Para de torcer, você vai quebrar meu pulso!

JAKE. (rindo por entre os dentes).Fazen'o que? O que fazen'o? Desde a janta?

FLORA. (gritando).Como diabos eu vou saber!

JAKE. Porque você tava bem aqui comigo, o tempo todo, cada segundo! Você e eu, meu amor, sentados aqui juntos se balançando, se balançando pra frente e pra trás, todos os minutos desde a janta! Você enfiou isso na cabeça agora?

FLORA. (choramingando).Solta!

JAKE.Enfiou na sua cabeça agora?

FLORA. Ta - ta - ta, solta!

JAKE. O que eu tava fazen'o então?

FLORA. Balançando! Pel'amor de Deus - balançando! (Ele a solta. Ela choraminga e esfrega o pulso, mas a impressão é que experiência não foi sem prazer para nenhum dos dois. Ela resmunga e choraminga. Ele agarra seus cachos soltos com a mão e dobra suas costas para trás. Ele tasca um beijo longo e molhado em sua boca.) 
signo da ausência ou da interrupção), dão aos seus textos um aspecto de incerteza, como se nada pudesse ser categoricamente afirmado a respeito daquilo que se desenrola no palco. Quando transposto seu texto para a cena, é Stanislávski quem insere o subtexto latente do fluxo dramático de suas peças para o universo sensível do espetáculo, carregando de materialidade tudo aquilo que, escrito, só aparece sutilmente delineado. Embora possa ser argumentado que esse é o papel primeiro do diretor, é necessário ressaltar que sua função estava ainda em processo de estabelecimento, sua atuação como mediador entre texto e espetáculo ainda era bastante recente, e os efeitos que isso produzia no teatro como um todo ainda estavam sendo explorados. ${ }^{226}$

Assim, é possível afirmar que a escrita dramatúrgica de Tennessee Williams, pelo controle que o escritor demonstra ter sobre as diversas facetas da linguagem teatral, aparenta amalgamar os papéis da partitura de palco e da dramaturgia, exibindo aspectos do estilo tchekhoviano e, também, stanislavskiano.

${ }^{226}$ Picon-Vallin argumentará, por exemplo, que é somente com o trabalho de Meierhold que a função do diretor atingirá todo o seu potencial. PICON-VALLIN, B. In. CAVALIERE, Arlete, e Elena VÁSSINA. Teatro Russo - Literatura e Espetáculo. São Paulo: Atelier Editorial, 2011. 


\section{A Pesquisa: uma trajetória}

A pesquisa aqui exposta exigiu um longo percurso e passou por variadas frentes de análise. De maneira geral, a unidade encontrada durante a trajetória, que acabou por se tornar o ponto central em torno do qual tudo se articulou, foi uma mudança substancial na visão daquilo que era tido como o "retrato fiel da realidade". Como parece ter ficado claro nos capítulos anteriores, aquele realismo que tem início no século XVIII com o desenvolvimento do realismo formal dos romances, conduziu o fazer dramatúrgico e teatral a inúmeras inovações. Tentou-se manter sempre em evidência o contexto histórico e o sistema de valores que se impunha na sociedade ocidental e como este encontrava-se expresso nas formas analisadas.

O rompimento com a forma rígida do drama burguês demonstrado pelas peças de Tchékhov, aponta para uma concepção da realidade pautada pelo pressuposto de que o homem não é livre para agir e escolher mas, isto sim, é condicionado pelos mais diversos elementos que compõem suas circunstâncias de existência, como a esfera social da qual provém, incluindo suas implicações históricas. Além disso, vê-se como esse aguçado olhar historicista, cuja ascendência se dá por meio da influência do movimento romântico na cultura ocidental, está atrelado ao crescente individualismo e sua atenção para a subjetividade pessoal.

Eliminada a ação pela falta de poder de agência dos personagens, o drama é levado a encontrar outro mecanismo que o desenvolva, substituindo a ação dramática e os conflitos externos pelo desencadeamento circunstancial, no qual o conflito se dá na interioridade em relação ao mundo externo. Essas mudanças foram pontuadas nos dramas de Tchékhov e de Tennessee Williams, encontrando ali, um primeiro eixo de análise comparativa.

Em seguida, procurou-se analisar, dadas as mudanças nas possibilidades representativas do drama, como os conflitos sociais puderam ser encenados por meio do recorte metonímico que, por meio de personagens, permitiu o vislumbre da complexa teia de tensões que se estabelecem entre diferentes classes. Em Tchékhov, em cujo país lentamente se estabelecia o sistema capitalista, com a ascensão da classe burguesa e a 
decadência das classe rurais da aristocracia, foi possível perceber como essa transição atuava perante as diferenças entre os valores sustentados pelas diferentes classes.

O conceito de posição de classe, defendido por Bourdieu, foi requerido para explicar as similaridades que a transição russa tinha com aquela que ocorreu nos Estados Unidos. Argumentando que as altas classes rurais do sul norte-americano ocupavam posição estrutural semelhante àquela das classes russas, pode-se ponderar que as tensões geradas entre esta e os costumes burgueses provindos do norte - que se tornam dominantes após a Guerra Civil - desenvolveram um sentimento idealizado nos escritores do sul, que passaram a enfatizar esse processo de decadência como análogo àquele pelo qual as aristocracias europeias passaram, muito embora estivessem longe de serem aristocratas.

Ao mesmo tempo, tais tensões teriam se cristalizado na forma bastante idealizada de um conflito cultural, no qual se opõem o pensamento materialista, "pragmático e vulgar" das classes ascendentes ao pensamento "culto e humanizado" das classes decadentes. A idealização dos "aristocratas" deve ser entendida não como nostalgia, mas como um expediente retórico de crítica à nova cultura que os escritores viam se estabelecer. Seria possível imaginar que Tchékhov e Tennessee, de fato, estivessem alienados da realidade que essa classe representava tanto na Rússia quanto nos Estados Unidos? A análise de As Três Irmãs e Um Bonde Chamado Desejo trouxe, então, maior materialidade a esse argumento, que se constituiu como segundo eixo de análise.

As diferentes análises aqui propostas não são exaustivas, mas focadas em apresentar pontos específicos das dramaturgias de cada um dos dramaturgos estudados. A intenção deste trabalho é apenas apresentar uma possibilidade alternativa, de forma alguma excludente das demais, à leitura das obras de Tchékhov e Tennessee. Trata-se, talvez, mais de uma proposta do que de uma afirmação categórica.

O último eixo de análise concentrou-se no fenômeno da recepção americana de Tchékhov e do Teatro de Arte de Moscou. Foi possível perceber as diversas relações não só entre Tchékhov, Tennessee Williams e Stanislávski, mas entre suas conquistas e a cultura na qual se está hoje inserido, dada a aparente atualidade de suas peças. Como 
resultado da pesquisa, ao lado de elementos e possibilidades comparativas, surgem também problematizações acerca do momento presente. Qual seria hoje o poder da arte de efetuar mudanças concretas na realidade? 


\section{ANEXOS}




\section{ANEXO I -}

Breve comentário e tradução de: $O$ nascimento de uma arte 


\title{
Breve comentário e tradução de: $O$ nascimento de uma arte ${ }^{227}$
}

O nascimento de uma arte foi escrito em 1937 por Tennessee Williams como trabalho final da matéria Princípios e Problemas da Literatura, ministrada por Otto Heller. O trabalho obteve nota D e, em sua capa, Heller anotara os seguintes comentários:

\begin{abstract}
Numeração de páginas? Este trabalho não cumpre de maneira alguma os requerimentos exigidos de um trabalho final, como já foi indicado repetidamente. (...) Tudo isso, ou quase tudo, foi escrito sem referência ou relação aos padrões literários e estudos críticos vistos durante o curso. ${ }^{228}$
\end{abstract}

Não obstante a nota recebida, é possível notar em seu texto uma sensibilidade curiosa em sua percepção do estilo tchekhoviano. Tennessee comenta em detalhes muitas das características mais marcantes do escritor, como as diferentes inovações formais deste frente ao drama tradicional, a presença de temas épicos em seus textos, a ênfase dada à atmosfera de suas peças e seu caráter lírico.

Seus comentários acerca de seu escritor preferido adquirem singular interesse frente à análise das possibilidades comparativas entre as obras de ambos. Em alguma medida, quase todas as qualidades que Tennessee admira na escrita de Tchékhov podem ser encontradas também em seus dramas, em especial naqueles do início de sua carreira.

Este trabalho talvez possa ser visto como prova inicial de uma admiração que se manteria viva até o final da carreira de Tennessee, marcada pela publicação de sua adaptação de A Gaivota, The Notebook of Trigorin ${ }^{229}$, em 1981, apenas dois anos antes de

\footnotetext{
227 Texto publicado pela primeira vez em BAK, John. Tennessee Williams - New Selected Essays: Where I live. New York: New Directions, 2009. p.246-253

${ }^{228}$ Ibidem. p. 292.

${ }^{229}$ WILLIAMS, T. The Notebook of Trigorin. New York: New Directions, 1997.
} 
sua morte.

\section{O nascimento de uma arte (Anton Tchékhov e o novo teatro)}

\section{TCHÉKHOV E SEUS CRÍTICOS}

Tchékhov foi um desses raros artistas que possuíam o atributo de gênio, no sentido em que exerceu uma profunda e revolucionária influência sobre a arte de seu tempo. Provavelmente o precursor do naturalismo no teatro russo, Tchékhov foi um dos pioneiros do naturalismo na literatura mundial. Ele é universalmente reconhecido como o melhor escritor de contos, comparável somente a Maupassant. Sua arte era peculiarmente adotada dessa forma particular. Tchékhov era um lírico, criador de climas e atmosferas, um profundo analista do caráter humano. Sua obra tem, necessariamente, um público limitado. Aqueles que exigem narrativas excitantes, esperteza superficial, dramas comoventes, encontram pouco em seus textos que possa estimular seus gânglios. Eles o descrevem como sem graça, mórbido, incolor. Como a maioria dos russos, Tchékhov era intensamente introvertido. Interessava-se primeiramente pela vida da alma. Portanto, seu forte não eram os enredos. A maioria de suas histórias parece, para críticos ortodoxos, meras anedotas. Eles também dispensam seus personagens como não naturais. Isso é algo paradoxal. As pessoas aceitam o convencional, personagens banais de ficções lugarcomum, como se fosse perfeitamente natural, mas quando encontram no palco pessoas transpostas diretamente da vida, que são réplicas animadas e falantes delas mesmas, elas imediatamente gritam que essas personagens são exageradas, irreais, ridículas - "eles se comportam como lunáticos - são absurdamente artificiais!” O que prova quão pouco conhecemos de nós mesmos! [...]

\section{UM HOMEM SEM IDEIAS}

Durante sua vida, embora gozasse de considerável popularidade, Tchékhov foi 
depreciado por alguns leitores que o consideravam um escritor sem ideias. Esta acusação é algo verdadeiramente estranho de ser dito sobre qualquer artista. A arte, como já foi provado, não se dirige à razão ou ao intelecto, mas àquele departamento especial da mente conhecido como o senso estético. É absolutamente possível que grandes obras de arte sejam totalmente desprovidas de qualquer apelo racional. Para a materialização disso, basta que apontemos o charme da poesia imagética, muita da qual é totalmente desprovida de significado, mas que, mesmo assim, excita nos amantes de poesia uma poderosa resposta emocional. Toda a beleza abstrata é desprovida de ideias no sentido estrito. Mais do que isso, eu acho que ideias podem ser um estorvo, ao invés de um ganho, para alguns tipos de arte criativa. Ideias, no estrito senso, são coisas efêmeras: verdade e beleza são constantes. Em Ibsen, não sobreviveram os temas sociais mas, sim, a irrefutável maestria artística com a qual escrevia. É a Vida neles e não suas ideias que mantêm sua validade - muito depois da resolução dos problemas sociais. Se as peças de Shaw sobreviverem, será pela mesma razão. Então a falta de uma doutrina sociológica ou de uma "ideia" original não devem ser consideradas defeitos fatais em Tchékhov.

No entanto, é somente no sentido mais limitado que se pode afirmar que faltam ideias em Tchékhov. Como pode um homem que faz críticas verdadeiras à vida ser considerado desprovido de ideias? Suas ideias são tão amplas, tão compreensivas e tão harmoniosamente difundidas por todas suas obras que elas escapam à atenção de críticos superficiais. Essa é a forma que as "Ideias" devem ter na literatura. Elas não devem parecer artificialmente inseridas. Elas não devem chamar muita atenção para si. Elas devem ser tecidas imperceptivelmente na totalidade da obra, e é desta maneira que elas se articulam nos textos de Tchékhov.

Eu duvido bastante que Tchékhov possa ser classificado como de direita ou esquerda, no sentido popular que os termos têm. Seria isso um defeito ou um ganho? Eu acredito que é definitivamente um ganho. Seu espírito é vasto demais para o partidarismo. Ele era derrotista? Essa acusação talvez seja válida. Mas não acredito que seja condenatória. No entanto, deve ser lembrado que ele viveu em um período e em uma sociedade de derrotas. O derrotismo não era tanto seu quanto da sociedade que ele representava. Hoje, nós chamamos de geração perdida aquela que surgiu imediatamente 
após a guerra. A geração russa de Tchékhov era ainda mais desesperadamente perdida. E eles sabiam disto. Mas mesmo no triste crepúsculo daquela ordem social, algumas das melhores obras de arte tiveram existência. Foi o canto do cisne - que dizem ser a mais bela das canções.

\section{TCHÉKHOV E O NOVO TEATRO}

Os problemas do teatro são tão peculiares que normalmente demandam uma vida toda de aplicação e estudo. A maior parte dos grandes dramaturgos viveram suas vidas associados, de uma maneira ou outra, ao teatro. Ibsen foi sempre um dramaturgo. Shakespeare foi ator e gerente de teatro. Eugene O’Neill era filho de um tespiano veterano. A lista ainda poderia ser expandida. Mas Tchékhov nem ao menos se interessou pelo teatro até quase o final de sua carreira. Aproximadamente nos últimos dez anos de sua vida. E, não obstante tão pouco tempo, ele atingiu a mais absoluta maestria. Ele voou direto contra a cara do antigo teatro: desafiou suas convenções: criou um teatro novo para o qual o público geral estava despreparado: produziu quatro ou cinco peças que se posicionam dentre as maiores obras dramáticas de todos os tempos.

Os primeiros escritos dramáticos de Tchékhov foram duas comédias farsescas em um ato chamadas "O Urso" e "O Pedido de Casamento". Foram vaudevilles extremamente populares e, diferentemente da maioria das obras tchekhovianas, podem ser apreciadas pela cultura de massa do público de língua inglesa. Sua primeira peça longa foi Ivanov, uma peça mais convencional do que o restante de seus trabalhos, que gozou de sucesso convencional quando apresentada no teatro Imperial de São Petersburgo.

A primeira produção importante de Tchékhov foi A Gaivota, produzida pelo mesmo teatro, que foi um fracasso miserável. Esse fracasso demonstrou a inabilidade metodológica do antigo teatro para traduzir a arte moderna para o palco. $\mathrm{O}$ elenco foi escolhido dentre os favoritos do palco. O próprio Tchékhov assistiu aos ensaios. Mas, desde o início, o fracasso estava aparente. Eles não conseguiam se livrar dos maneirismos 
e vozes banais que eram, é claro, totalmente inadequados para a nova arte. Tchékhov estava desesperado. "Por que eles não param de atuar?" ele exclamou. Ninguém sabia o que ele queria dizer. Eles estavam tão acostumados a se expressarem daquela maneira, naqueles desgastados clichês discursivos e gestuais que não podiam se utilizar de mais nada. A produção foi complexa e meticulosa. Mas um fracasso completo. O público - no estilo russo - demonstrou seu desprezo ruidosamente. Eles chiaram durante o intervalo, desataram em rudes gargalhadas no clímax quando o desafortunado jovem Treplieff se dá um tiro. Tchékhov, durante o fiasco, andava pelos bastidores em torpor. Depois disso, ele desapareceu do teatro: dizem que ele andou por horas na chuva e pegou uma gripe que piorou consideravelmente sua saúde, já comprometida. Na manhã seguinte, sem se encontrar com ninguém, ele deixou São Petersburgo. Em uma carta, declarou que nem que vivesse até os setecentos anos escreveria outra peça.

\section{O TEATRO DE ARTE DE MOSCOU}

Nesse período, umas das coisas mais importantes na história dramática estava tomando forma. Os dois grandes empreendedores, Stanislávski e Dântchenko, estavam planejando a criação de um novo teatro de arte em Moscou. Esse teatro deveria ter todas as virtudes que faltavam no velho teatro e nenhum de seus velhos defeitos. Buscaram seus membros não dos favoritos já estabelecidos, mas dentre novos e ambiciosos amadores que não se assustariam com métodos revolucionários. Hauptmann, Ibsen, Strindberg, Maeterlinck, Tolstói, Ibsen, Tchékhov eram os escritores cujas obras queriam encenar: em outras palavras, era um movimento naturalista.

Tinham como objetivo muitas reformas audaciosas. Era primeiro necessário criar um novo público e reeducar o antigo. Muitas práticas horríveis eram toleradas no antigo teatro. Quando agradava o público, era costumeiro que os atores agradecessem no meio da cena. Os favoritos avançavam para a frente do palco e agradeciam, enquanto os demais atores ficavam parados como bonecos esperando a ovação terminar, para que a ação prosseguisse. Isso era, claramente, fatal para a ilusão de realidade que as boas produções exigiam. 
O público muitas vezes se atrasava e era sentado durante a performance. Os corredores eram barulhentos. Havia música nos interlúdios. Chiados eram ilimitados. Todas essas práticas eram tabu no Teatro de Arte de Moscou.

Houve também muitas melhorias técnicas. Os cenários tradicionais foram descartados. No futuro, cada peça terá um cenário específico. A cenografia se tornou uma arte. A performance não deverá se arrastar durante os problemas mecânicos. Os cenários deverão ser trocados imediatamente sem o, antes inevitável, ruído. As cortinas devem ser operadas de maneira suave. E elas devem ser fechadas, não baixadas. Atenção cuidadosa deverá ser dada à iluminação. Sem luar verde e grudento. A orquestra pode ser eliminada: ela geralmente interrompe mais do que realça o clima das peças e, de qualquer forma, é um expediente artificial para a estimulação dos frequentadores teatrais. Ninguém deverá agradecer exceto ao final da peça.

É claro que as reformas principais seriam aquelas feitas na própria apresentação das peças. Deverá haver um novo estilo de atuação: uma atuação que independa de clichês discursivos e gestuais. Cada discurso e cada movimento serão pensados cuidadosamente e não deixados aos caprichos do virtuosismo das estrelas. Cada peça receberá tratamento individual. O velho método que deixava os atores principais comandar o espetáculo estava dispensado. A companhia deverá funcionar como ensemble, como uma unidade. A peça será a coisa. O Régisseur será o comandante e aquilo que ele disser será feito.

Haverá aulas de atuação. Todas as cenas, de cada nova peça, serão ensaiadas individualmente até que estejam completamente prontas. Ensaios serão muito mais meticulosos e intensivos do que jamais foi o caso do antigo teatro.

\section{O SUCESSO DE TCHÉKHOV NO NOVO TEATRO}

Apesar do fracasso de A Gaivota em São Petersburgo ter entristecido o dramaturgo, ele não destruiu sua reputação como escritor. Sentia-se que o fracasso dramático de autor tão competente poderia ser escusado. A saúde de Tchékhov piorava 
rapidamente e suas obras eram cada vez mais esparsas. Cada nova história era um evento literário. Agora que todos sabiam do seu curto tempo de vida, seu sucesso era ainda maior.

Dois anos depois da produção em São Petersburgo, Dântchenko começou a se corresponder com Tchékhov a respeito de uma produção de A Gaivota no Novo Teatro de Moscou. Foi necessária eloquente persuasão. Uma vez escaldado, Tchékhov estava muito mais tímido frente ao mundo teatral. "Talvez a peça não provoque uma tempestade de aplausos", escreveu Dântchenko, "mas, que uma produção genuína com qualidades espontâneas, liberta da rotina, provará um triunfo da arte - isto eu te garanto.” Duas cartas se seguiram até que Tchékhov se convencesse da nova produção.

Nesse período, a saúde de Tchékhov estava tão frágil que não poderia arriscar um inverno em Moscou. Assim, ele não estava presente na premiere de sua peça. A estreia foi um tremendo sucesso. Foi o completo reverso daquilo que havia ocorrido dois anos antes, em São Petersburgo. Assim, rapidamente o naturalismo se assumiu na Rússia!

Escrevendo sobre essa incrível estreia, Dântchenko diz: "A atmosfera estava carregada de excitação e perturbação, não só dentre aqueles que participavam de $A$ Gaivota, mas no teatro inteiro. Havia um sentimento de uma tempestade no horizonte. A própria existência desse jovem teatro dependia dessa performance." Stanislávski, o outro empreendedor, estava tão nervoso que, no dia anterior, havia implorado que Dântchenko retirasse seu nome dos créditos. Ele não queria estar associado a esse fracasso inevitável. Dântchenko, no entanto, tinha certeza do sucesso da peça.

O público estava hipnotizado durante a performance. Quando a cortina final se fechou, citando das memórias de Dântchenko: “Algo que só pode acontecer no teatro uma vez a cada década ocorreu; a cortina fechou e houve silêncio, um silêncio completo no público e no palco; era como se todos prendessem a respiração, como se ninguém tivesse entendido direito; havia sido uma visão? Um sonho? Uma triste canção de uma melodia familiar? De onde viera? De qual lembrança de todos presentes? Essa atmosfera permaneceu por um longo período, tão longo que aqueles no palco decidiram que haviam fracassado, fracassado tão completamente que nem seus amigos no público ousavam 
aplaudir. Um calafrio nervoso tomou os atores, beiravam a histeria. De repente, algo aconteceu no auditório. Era como se uma represa houvesse rompido, uma bomba explodido - em um só momento houve uma onda ensurdecedora do aplauso de todos, amigos e inimigos."

A ovação prodigiosa continuou até que os atores todos se abraçaram e choraram. Dântchenko apareceu no palco para responder aos insistentes clamores pelo autor e perguntou se eles o autorizavam enviar um telegrama a Tchékhov. E essa ovação se estendeu por um período incrivelmente longo.

"Um novo teatro havia nascido!"

\section{RESENHAS DE VÁRIAS PEÇAS DE TCHÉKHOV}

\section{A Gaivota}

Esta, como as demais grandes peças de Tchékhov, é uma tragédia da inação. Eu não tentarei dar os nomes russos dos personagens, são difíceis de pronunciar e escrever, e eu devolvi seus livros para a biblioteca.

A figura principal da peça é um jovem escritor cuja mãe é uma famosa atriz. Ele tem por volta de 25 anos. Sua mãe sempre o deixou em sua casa de campo. Ela é um desses milagres de juventude perpétua, que nunca deixa de fascinar os homens. Ela tem vergonha de ter um filho tão velho e a presença dele sempre a deprime. Existe uma sugestão de complexo de Édipo no caráter do menino, embora ele não tenha um pai para invejar. A indiferença de sua mãe, provavelmente, fez com que sua mente se voltasse para dentro. Ele se tornou introvertido e terrivelmente infeliz. [...].

A ideia essencial por trás dessa peça é a inutilidade frustrante de certas vidas: são como gaivotas abatidas ao acaso. $\mathrm{O}$ que acontece com eles está majoritariamente fora de seu controle. Suas circunstâncias os aprisionam. Nina é aprisionada por seu amor desesperançado por Trigórin, que ama a superficial atriz mais velha. Macha é aprisionada por seu amor por Konstantín, Konstantín por seu amor por Nina. É um emaranhado no 
qual todos são vítimas: não têm a quem culpar.

O charme da peça é sua marcante atmosfera e a mordacidade emocional criada a cada cena. Ela possui uma soberba unidade de cor: uma espécie de crepúsculo nostálgico a permeia de início a fim. Há sempre um clima de finais de tarde de verão com seus vagalumes e o musical zumbido de grilos. Tudo o que acontece tem uma qualidade onírica: mas, ao mesmo tempo, é real como se nós mesmos fossemos aqueles trágicos protagonistas.

\section{Tio Vânia}

Este é outro quadro da vida rural russa. É um tanto menos melancólico do que $A$ Gaivota e não tão lírico. Similarmente, é uma tragédia da inação: um drama estático. Ivan Voitski (ou Tio Vânia) passou toda sua vida administrando as propriedades de seu cunhado. Sua irmã está morta. A propriedade era seu dote e Vânia sacrificou sua própria herança e abriu mão de sua própria existência para preservá-la. Ele fez de seu cunhado, um famoso acadêmico, seu ídolo. [...]

O tema desta peça é o sacrifício inútil de determinadas vidas a outras. É uma mordaz caracterização: todas as pessoas da peça são tipos humanos vívidos. Seu realismo é soberbo. Existe uma falha no uso de solilóquios. Isto era, sem dúvida, um expediente aprovado pelo teatro russo mas, para mim, sempre prejudicou a ilusão de realidade.

\section{O Jardim das Cerejeiras}

Esta obra prima apoteótica de Tchékhov foi a última de suas quatro grandes peças. Foi produzida pela primeira vez no Teatro de Arte de Moscou quatro meses antes da morte do escritor na Alemanha, para onde havia ido numa última tentativa de vencer sua doença. É a melhor acabada, a mais tocante, a mais lírica de suas peças.

Eu li O Jardim das Cerejeiras duas vezes e assisti uma produção sua no Little 
Theatre de St. Louis e, a cada contato, minha apreciação por ela aumentou. Para mim, é a mais comovente peça do realismo já criado para o palco.

Há uma grande divisão de opinião dentre os informados sobre este drama, e as respostas dependem menos de suas capacidades intelectuais e críticas do que de seus temperamentos pessoais. Já ouvi muitas pessoas bem mais inteligentes do que eu dizerem que não havia nada nela, que as personagens são fantásticas, a história é sem sentido e a dramaturgia muito lenta e ineficiente. Acho que esses críticos são, possivelmente, pessoas de caráter extrovertido, que não conseguem entender a intensa introspecção do realismo russo.

Também há o fato da peça sofrer de uma imensa desvantagem em todas suas produções para o palco americano. O Jardim das Cerejeiras tem um elemento cômico muito forte - em muitos aspectos, é quase uma comédia de costumes russa - mas este elemento é frequentemente ignorado em suas produções em inglês, resultando numa peça muito esmorecida, na qual a melancolia é enfatizada até o ponto da morbidez, e o toque leve e líricodesaparece.

Isto nunca foi tão aparente quanto na produção feita no Little Theatre de St. Louis. A falha maior desta produção foi em seu elenco. A mulher que fez o papel de Raniévskaia era muito firme, segura e tinha um aspecto por demais vigoroso. Ela parecia uma típica mulher de negócios americana e não conseguia evitar de agir como uma. Sua caracterização, embora sincera e meticulosa, não foi convincente em nenhum momento. Nenhum dos outros personagens, com exceção do Director Strickland no papel de Leonid, parecia captar a atmosfera nostálgica da peça.

Para produzir essa peça é necessário ter um elenco especialmente escolhido para a introspecção e sensibilidade psicológica. A atmosfera é a coisa mais importante. A não ser que seja captada, está tudo fadado ao fracasso. Isso é igualmente válido, é claro, para as demais peças de Tchékhov.

O tema de $O$ Jardim de Cerejeiras é essencialmente o fim de uma antiga ordem e o começo de uma nova. É um tema épico apresentado com maravilhosa delicadeza. O 
jardim de cerejeiras é símbolo do gracioso e nostálgico charme das coisas antigas. No final, quando ouvimos, na casa de campo deserta, o som abafado e oco dos machados sobre as árvores, percebemos que não é só o jardim, mas uma civilização inteira que está sendo impiedosamente derrubada para abrir espaço para a nova.

\section{CARACTERÍSTICAS GERAIS DOS DIÁLOGOS}

Em seus diálogos, Tchékhov se distancia totalmente da tradição das peças "bemfeitas". Se seu discurso fosse cuidadosamente analisado, acredito que se descobriria que 40 ou 50 por cento deles não têm relação direta com o andamento da história. Eles existem somente para o bem da caracterização e da criação de atmosferas. Nas peças bem-feitas, cada frase tem o intuito de fazer o enredo avançar. Até em Ibsen não é possível achar falas supérfluas. A maestria artística de Ibsen era maior do que a de Tchékhov, mas, eu acho, ele nunca atingiu realismo tão completo. Está contido na

aparente superficialidade das falas aquilo que possibilita um efeito tão mágico de verossimilhança. Não é superficialidade verdadeira, é só aparente. Na verdade, Tchékhov era um artista muito seletivo. Cada fala pertence exatamente ao seu lugar. Cada uma contribui para o efeito total do quadro.

A poesia de Tchékhov é um contraste gritante perante Eugene O’Neill. A de O’Neill é obvia e artificial. Quando seus personagens se tornam líricos, imediatamente suspeitamos que eles tomaram uns drinques escondidos. $\mathrm{O}$ lirismo de Tchékhov, por outro lado, é intrínseco. Ele nunca produz o efeito de ser colado ou derramado sobre a peça. Ele permeia a totalidade da obra. Quando uma fala lírica ocorre, ela ocorre inevitavelmente, no calor da excitação emocional que faz dessa linguagem absolutamente adequada e natural.

Bibliografia:

Nemirovitch - Dântchenko - My Life in the Russian Theatre

Frank W. Chandler - Aspects of Modern Drama 
Constance Garnett (Tradutora) - Letters of Anton Chekhov to his Family and Friends

Collected Plays of Chekhov. 


\section{ANEXO II - \\ Reportagens selecionadas do New York Times}




\section{Referências bibliográficas organizadas por temas}

\section{ANTON TCHÉKHOV E O TEATRO RUSSO}

ANGELIDES, Sophia. A. P. Tchékhov: Cartas para uma poética. São Paiulo: Editora Uneso, 1995.

BENEDETTI, Jean (Org.). The Moscow Art Theatre Letters. New York: Routledge, 1991.

BARBOSA, Tieza Tisse. As partituras de Stanislávski para As Três Irmãs de Tchékhov: Tradução e análise da composição espacial da encenação. São Paulo: 2012. Dissertação de mestrado em Literatura e Cultura Russa - Faculdade de Filosofia, Letras e Ciências Humanas, Universidade de São Paulo.

BROOK, P.O Cerejal, Uma Imensa Vitalidade. In. Théâtre en Europe. № 2 (Avr. 1984).

CAVALIERE, Arlete e Vássina, Elena. Teatro Russo - Literatura e Espetáculo. São Paulo: Ateliê Editorial, 2011.

CAVALIERE, Arlete. Teatro Russo - Percurso para um estudo da paródia e do grotesco. São Paulo: Humanitas e Fapesp, 2009.

CHEKHOV, Anton. Chekhov on Theatre. Edição para Kindle. Edição: Stephen Mulrine. New York: Opus, 2012.

CHEKHOV, Anton P. The Note-book of Anton Chekhov. Project Gutenberg, 1921.

CHEKHOV, Anton. Plays. Tradução: Peter Carson. London: Penguin Books, 2002.

—. The Complete Plays of Anton Chekhov. Tradução: Laurence SENELICK. New York: Norton \& Company, 2006.

ERLICH, Victor (Org.). Twentieth -Century Russian Literary Criticism. New Haven: Yale University Press, 1975.

GASSNER, John. Mestres do Teatro II. São Paulo: Perspectiva, 2011.

GOTTLIEB, Vera, e Paul ALLAIN. The Cambridge Companion to Chekhov. Cambridge: Cambridge University Press, 2000. 
GUINSBURG, Jacó. Stanislávski e o Teatro de Arte de Moscou. São Paulo: Editora Perspectiva, 2006.

—. Stanislávski, Meierhold \& Cia. São Paulo: Editora Perspectiva, 2008.

HRISTIC, Jovan. “A Forma Dramática em Tchékhov.” In: Le Théâtre de Tchekov, tradução: para o português de Regina Guimarães, 175. Lausanne: L'âge D'homme, 1982.

LEACH, Robert, e BOROVSKY, V. A History of Russian Theatre. Cambridge: Cambridge University Press, 2006.

NABOKOV, Vladimir. Lectures on Russian Literature. New York: Harcourt Books, 1981.

NASCIMENTO, Rodrigo Alves do. Tchékhov no Brasil: a construção de uma atualidade. São Paulo: 2013, 344f. Dissertação (Mestrado em Literatura e Cultura Russa) - Faculdade de Filosofia, Letras e Ciências Humanas, Universidade de São Paulo.

NEMIROVITCH-DANTCHENKO, Vladimir. My Life in The Russian Theatre. New York: Theatre Arts Book, 1968.

PICON-VALliN, B. A Cena em Ensaios. São Paulo: Perspectiva, 2008.

—. Meierhold. São Paulo: Perspectiva, 2013.

RIPELLINO, Angelo Maria. O Truque e a Alma. São Paulo: Editora Perspectiva, 1996.

SENELICK, Laurence. The Chekhov Theatre. Cambridge: Cambridge University Press, 1997.

SLONIM, Marc. From Chekhov to the Revolution - Russian literature 1900-1917. New York: Oxford University Press, 1962.

- Russian Theater - from the empire to the Soviets. Cleveland: The World Publishing Company, 1961.

STANSILAVSKI, Constantin. My Life in Art. New York: Theatre Arts Books: Robert M. MacGregor, 1948

STANISLAVSKY, K.S. The Seagull Produced by Stanislavsky. Edição:

S.D.BALUKHATY. London: Dennis Dobson LTD, 1952.

SZONDI, Peter. Teoria do Drama Moderno. 2a Edição. São Paulo: Cosac Naify, 2012.

TCHÉKHOV, Anton P. Os Males do Tabaco - e outras peças em um ato. 2. São Paulo: Ateliê Editorial, 2003.

TCHÉKHOV, Anton Pavlovitch. O Jardim das Cerejeiras seguido de Tio Vânia. Tradução: Millôr Fernandes. Porto Alegre: L\&PM, 2014. 
-. Teatro II - As Três Irmãs e O jardim das Cerejeiras. Tradução: Gabor Aranyi. Mairiporã: Editora Veredas, 2013.

WILLIAMS, Raymond. Drama em Cena. Sâo Paulo: Cosac Naify, 2010.

—. Tragédia Moderna. 2a Edição. São Paulo: Cosa Naify, 2011.

\section{CULTURA E HISTÓRIA RUSSAS}

BERLIN, Isaiah. A Força das Ideias. São Paulo: Companhia das Letras, 2005.

—. Russian Thinkers. London : Penguin Books, 2008.

BILLINGTON, James H. The Icon and The Axe. New York: Vintage Books, 1970.

ERLICH, Victor (Org.). Twentieth -Century Russian Literary Criticism. New Haven: Yale University Press, 1975.

FIGES, Orlando. A People's Tragedy - The Russian Revolution. London: Penguin Books, 1996.

FILHO, Daniel Aarão Reis. As Revoluções Russas e o Socialismo Soviético. São Paulo: Editora Unesp, 2003.

FRANK, Joseph. Pelo Prisma Russo . São Paulo: Edusp, 1992.

HAMILTON, G. H. The Art and Architecture of Russia. 2a Edição. Middlesex, England: Penguin Books, 1975.

LEACH, Robert, e Victor. (Eds.) BOROVSKY. A History of Russian Theatre. Cambridge: Cambridge University Press, 2006.

LEATHERBARROW, William, e Derek OFFORD, . A History of Russian Thought. Tradução: Edição para Kindle. Cambridge: Cambridge University Press, 2010.

RIASANOVSKY, Nicholas V. \& STEINBERG, Mark D. A History of Russia. New York: Oxford University Press, 2005.

VOLKOV, Solomon. The Magical Chorus. Kindle. New York: Alfred A. Knopf, 2008. 


\section{ANTON TCHÉKHOV E O TEATRO RUSSO NOS ESTADOS UNIDOS}

ADLER, Stella. Stella Adler on Ibsen, Strindberg and Chekhov . Edição para Kindle ( Vintage ebooks). New York: Alfred A. Knopf, 1999.

GORDON, Mel. Stanislavsky in America: An actor's workbook. New York: Routledge, 2010.

HOHMAN, Valleri J. Russian Culture and Theatrical Performance in America - 18911933. New York: Palmgrave Mcmillan, 2011.

MEISTER, Charles. Chekhov's Reception in England and America. In. American Slavic and East European Review, 12.1 de 1953: 109-121.

TENNESSEE WILLIAMS E O TEATRO NORTE - AMERICANO

ADLER, Stella. Stella Adler on America's master Playwrights. Edição para Kindle. Edição: Barry PARRIS. Ney York: Alfred A. Knopf, 2012.

BIGSBY, Christopher W. E. Modern American Drama 1945 - 2000. Edição para Kindle. Cambridge: Cambridge University Press, 2000.

BLOOM, Harold, ed. Bloom's Modern Critical Views: Tennessee Williams. Versão pdf. Nova Iorque: Bloom's Literary Criticism, 2007.

BRONNER, Edwin. The Encyclopedia of the American Theatre 1900-1975. San Diego: A.S.Barnes \& Company, INC., 1980.

BUTSCH, Richard. The Making of American Audiences - from stage to television, 17501990. New York: Cambridge University Press, 2000.

COSTA, Iná Camargo. Panorama do Rio Vermelho. São Paulo: Nankim Editorial, 2001.

FALK, Signi. Tennessee Williams. Boston: Twayne Publishers, 1985.

FLECHE, Anne. Mimetic Disillusion. Tuscaloosa: The university of Alabama Press, 1971.

GORDON, Mel. Stanislavsky in America: An actor's workbook. New York: Routledge, 2010. 
ILARI, Mayumi Denise Senoi. 27 Wagons Full of Cotton, Baby Doll e Tiger Tail: Recriações da História Social Norte-Americana no Teatro de Tennessee Williams. Campinas, 2000.

KOLIN, Philip. Tennessee Williams: A Guide to Research and Performance. Edição para Kindle. Westport: Greenwood, 1998.

KRASNER, David, ed. A Companion to Twentieth entury American Drama. Malden: Blackwell Publishing, 2005.

LEAVITT, Richard F. e HOLDITCH, Kenneth. The World of Tennessee Williams. New Jersey: Hansen Publishing Group, 2011.

MCCULLERS, Carson. The Mortgaged Heart. Edição para Kindle. London: Penguin Books, 2008.

MURPHY, Brenda. Tennessee Williams and Elia Kazan - A collaboration in theatre. New York: Cambridge University Press, 1992.

RULAND, Richard \& BRADBURY, Malcolm. From Puritanism to Postmodernism - A history of american literature. New York: Penguin Books USA, 1992.

WILLIAMS, Raymond. Drama em Cena. Sâo Paulo: Cosac Naify, 2010.

—. Tragédia Moderna. 2a Edição. São Paulo: Cosa Naify, 2011.

WILLIAMS, Tennessee. 27 Wagons Full of Cotton - and other one-act plays. London: John Lehmann, 1949.

—.American Blues. New York: Dramatists Play Service INC., 1990.

—. Collected Stories. London: Minerva, 1985.

—.Memoirs. New York: Bantam Book, 1976.

—. Notebooks. London: Yale University Press, 2006.

—. Plays 1937 - 1955. New York: Library of America, 2000.

—. Plays 1957 - 1980. New York: Library of America, 2000.

—. The Notebook Of Trigorin. New York: New Directions, 1997.

—. The Selected Letters of Tennessee Williams. Vols. II ( 1945 - 1957). New York: New Directions, 2004.

—. The Selected Letters of Tennessee Williams. Vols. I ( 1920 - 1945). New York: New Directions, 2000. 
-.Conversations with Tennessee Williams. Ed. DEVLIN, A.J. Jackson: University Press of Mississippi, 1986.

-.Tennessee Williams - New Selected Essays: Where I live. Ed. BAK, J. New York: New Directions, 2009.

WILMETH, Don B. \& BIGSBY, Christopher. The Cambridge History of American Theatre (vol. III). New York: Cambridge University Press, 2005.

\section{CULTURA E HISTÓRIA NORTE-AMERICANAS}

AYERS, Edward L. Southern Crossing - A History of the American South. Oxford: Oxford University Press, 1995.

AYERS, Edward L., e Bradley C. MITTENDORF. The Oxford Book of the American South

- Testimony, Memory, and Fiction. New York: Oxford University Press, 1998.

COBB, James C. Away Down South - A History of Southern Identity. New York: Oxford University Press, 2005.

GOETZMANN, William H. Beyond The Revolution - A History of American Thought from Paine to Pragmatism. New York: Basic Books, 2009.

KARNALl, Leandro. História dos Estados Unidos. São Paulo: Editora Contexto, 2011.

MOLKE-HANSEN, David. "Between Plantation and Frontier: The South of William Gilmore Simms.” In: William Gilmore Simms and the American Frontier, por John C. GUILDS. Georgia: University of Georgia Press, 1997.

WOODWARD, C. Vann. The Burden of Southern History. Baton Rouge: Louisiana State University , 2008.

\section{HISTÓRIA E TEORIA GERAL DO TEATRO E DA ARTE}

ADORNO, Theodore. Aesthetic Theory. Edição: Gretel Adorno e Rolf Tiedemann. Tradução: Robert Hullot-Kentor. Londres: Bloomsbury Revelation, 2013.

BAKHTIN, Mikhail. Epos e romance: sobre a metodologia do estudo do romance. In Questões de literatura e de estética: a teoria do romance. Trad. BERNADINI, Aurora F. et al. 4. ed. São Paulo: Editora UNESP, 1998. 
BERTHOLD, Margot. História Mundial do Teatro. São Paulo: Editora Perspectiva, 2010. BOURDIEU, Pierre. A Economia das Trocas Simbólicas. São Paulo: Editora Perspectiva, 2005.

CARLSON, Marvin. Teorias do Teatro - Estudo histórico-crítico, dos gregos à atualidade. São Paulo: Editora Unesp, 1995.

CORTÁZAR, J. Valises de Cronópios. São Paulo: Perspectiva, 2006.

COSTA, Iná Camargo. Sinta o Drama. Petrópolis: Editora Vozes, 1998.

ELIOT, T. S.; Tradição e Talento Individual. In. Ensaios. Rio de Janeiro: Art Editora, 1989.

GUMBRECHT, Hans Urlich. Atmosphere, mood, stimmung - On a hidden Potential of Literature. Tradução: Erik Butler. Stanford: Stanford University Press, 2012.

—. Our Broad Present - Time and Contemporary Culture. New York: Columbia University Press, 2014.

HAUSER, Arnold. História Social da Arte e de Literatura. São Paulo: Martins Fontes, 2003.

—. The Sociology of Art. Edição para Kindle. New York: Routledge, 1982.

HOBSBAWM, Eric J. The Age of Revolution. New York: Vintage Books, 1996.

JAMES, C.L.R. The Black Jacobins - Toussanit L'Ouverture and the San Domingo Revolution. 2a Edição. New York: Vintage Books, 1963.

KATZ, Leon. Cleaning Augean Stables - Examining Drama's Strategies. Edição para Kindle. Não consta, 2012.

KOSSELECK, R. "Espaço de experiência" e "horizonte de expectativa": duas categorias históricas. In.: Futuro Passado - contribuição à semântica dos tempos históricos. Rio de Janeiro: contraponto, 2006.

LUKÁCS, Gyorgi. Il Dramma Moderno. Milão: SugarCo Se Edizioni, 1967.

—. "The Sociology of Modern Drama." The Tulane Drama Review Vol. 9. No.4, Summer de 1965: 146-170.

MATHIA, P e POSTAN, M.M.The cambridge Economic History of Europe. Vol. 7. The Industrial Economies: Capital, labour and enterprise. Part 2 - The United States, Japan and Russia. Cambridge: Cambridge University Press, 1982. 
PALLOTINI, Renata. Dramaturgia: A Construção da Personagem. São Paulo: Perspectiva, 2013.

PICON-VALlin, B. A Cena em Ensaios. São Paulo: Perspectiva, 2008.

ROSENFELD, Anatol. O Teatro Épico. 2a Edição. São Paulo: Perspectiva, 2011.

—. Prismas do Teatro. São Paulo: Editora Perspectiva, 1993.

—. Texto/Contexto I. São Paulo: Perspectiva, 2006.

STEINER, George. No Castelo do Barba Azul. São Paulo: Companhia das Letras, 1991.

SARRAZAC, Jean Pierre. Léxico do Drama Moderno e Contemporâneo. São Paulo: Cosac Naify, 2012.

SZONDI, Peter. Teoria do Drama Burguês. Sâo Paulo: Cosac Naify, 2004.

—. Teoria do Drama Moderno. 2a Edição. São Paulo: Cosac Naify, 2012.

WATT, Ian; A Ascensão do Romance. São Paulo: Companhia das Letras. 2007.

WILLIAMS, Raymond. Drama em Cena. Sâo Paulo: Cosac Naify, 2010.

—. Tragédia Moderna. 2a Edição. São Paulo: Cosa Naify, 2011.

WOLF, Eric R. A Europa e os Povos Sem História. São Paulo: Edusp, 2009. 